\title{
GENERAL AND HOST-
} ASSOCIATED BACTERIOPHAGE INDICATORS OF FAECAL POLLUTION

\author{
Sihem Jebri \\ Centre National des Sciences et Technologies Nucleaires Technopole \\ Tunis, Tunisia

\section{Maite Muniesa} \\ University of Barcelona \\ Barcelona, Spain \\ Juan Jofre \\ University of Barcelona \\ Barcelona, Spain
}




\section{Copyright:}

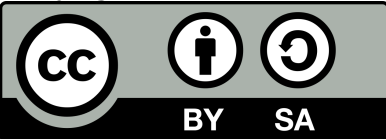

This publication is available in Open Access under the Attribution-ShareAlike 3.0 IGO (CC-BY-SA 3.0 IGO) license (http://creativecommons.org/licenses/by-sa/3.0/igo). By using the content of this publication, the users accept to be bound by the terms of use of the UNESCO Open Access Repository (http://www.unesco.org/openaccess/terms-use-ccbysa-en).

\section{Disclaimer:}

The designations employed and the presentation of material throughout this publication do not imply the expression of any opinion whatsoever on the part of UNESCO concerning the legal status of any country, territory, city or area or of its authorities, or concerning the delimitation of its frontiers or boundaries. The ideas and opinions expressed in this publication are those of the authors; they are not necessarily those of UNESCO and do not commit the Organization.

\section{Citation:}

Jebri, S., Muniesa, M. and Jofre, J. (2017). General and host-associated bacteriophage indicators of faecal pollution. In: J.B. Rose and B. Jiménez-Cisneros, (eds) Water and Sanitation for the 21st Century: Health and Microbiological Aspects of Excreta and Wastewater Management (Global Water Pathogen Project). (A.Farnleitner, and A. Blanch (eds), Part 2: Indicators and Microbial Source Tracking Markers), Michigan State University, E. Lansing, MI, UNESCO. https://doi.org/10.14321/waterpathogens.7

Acknowledgements: K.R.L. Young, Project Design editor; Website Design: Agroknow (http://www.agroknow.com)

Last published: February 28, 2017 


\section{Summary}

Different groups of bacteriophages have been comprehensively tested as indicators of faecal pollution and as markers for microbial source tracking (MST), as surrogate indicator for viral pathogens (index), and as potential indicators of public health risk. Because of their composition and structure, which are similar to other viruses, their outcome after remaining in water bodies and after water treatments mimics that of human and animal viruses much better than any other group of indicators. In this subchapter, bacteriophages will be organized in three working groups rather than in taxons, mostly because the current methods for their detection and quantification are adapted to these working groups. The three working groups of bacteriophages are taxonomically complex and diverse.

The groups that have been extensively studied are somatic coliphages, F-specific RNA bacteriophages, also named sexual coliphages though the two terms do not mean exactly the same, and bacteriophages infecting selected strains of Bacteroides. Somatic coliphages are bacteriophages infecting $E$. coli through the cell wall, Fspecific RNA bacteriophages infect $E$. coli through the sexual pili encoded by the $F$ plasmid and phages infecting Bacteroides strains are supposed to infect also through the cell wall.

Somatic coliphages and F-specific RNA bacteriophages can be used as indicators of general faecal contamination, whereas some selected host strains of Bacteroides can be used for MST since they preferably detect phages present in a given faecal source, as for example human waste water and excreta. As well, the proportions of genotypes of Fspecific RNA phages in a given sample can be used for MST.

Feasible and cost effective protocols standardized by the International Standardization Organization and the Unites States Environmental Protection Agency for the detection of infectious bacteriophages belonging to the three groups are available. Molecular methods for some phages are also available, but realistic molecular methods detecting all the phages contained in an entire group do not exist. In addition, practical and quite feasible bacteriophage concentration methods for up to one litre of sample are on hand.

The literature shows many data on the concentrations of the three groups of bacteriophages detected by standardized methods in point sources of faecal pollution from different areas of the world. The most abundant group are somatic coliphages that roughly exceed the numbers of RNA bacteriophages by a logarithm in all types of faecal sources and by 1.5 to 2 logarithms the numbers of phages infecting Bacteroides when these are enumerated with a strain appropriated to the source of faecal contamination. In all sources, E. coli uses to outnumber somatic coliphages by less than one logarithm.

Data on phages' persistence in different types of waters and resistance to waste water treatments are available, and allow outlining bacteriophages belonging to the three groups of phages from moderate to high persistence. Concentrations of the three groups of bacteriophages in contaminated aquatic and non-aquatic systems are also available and will be provided and discussed. The relative proportions between the numbers of $E$. coli and the three groups of bacteriophages change after tertiary treatments and after prolonged persistence in the environment, to the extent that the phages, mostly somatic coliphages outnumber E. coli.

In contrast, sound data on the meaning of enumerating bacteriophages to infer either the occurrence of intestinal pathogens, especially viruses, or the health risks for humans are scarce and frequently incomplete. The rather rare information available will be reported and discussed.

\section{Bacteriophages as indicators of general and host-associated faecal pollution}

\subsection{General Characteristics of Bacteriophages (Phages)}

Bacteriophages or viruses that infect bacteria are extremely abundant in nature, probably the most abundant life form on Earth. They outnumber bacteria in most studied habitats (Weinbauer, 2004), including human and animal -associated microbial communities (Letarov and Kulikov, 2009).

Phages which infect faecal bacteria are important virus indicators and viral surrogates for wastewater treatment efficacy. They are very useful in pollution assessment and control but like all phage carry on very specific activities in nature including in sewage and wastewater environments.

Phage infect and lyse bacteria thus they contribute to bacterial mortality, releasing organic compounds. They have an important impact on the cycling of organic matter in the biosphere (Suttle, 1994). On the other hand, they control microbial diversity by selecting for some types of bacteria that are resistant to their attack. As well, many phages can mobilize genetic material among different host bacteria in a process known as transduction. By transduction, genetic material can be introduced into a bacterium by a phage that has previously replicated in another bacterium, in which it packaged random DNA fragments (generalized transduction) or the DNA adjacent to the prophage attachment site (specialized transduction).

Phages can only replicate in metabolizing host cells. Once within a host bacterium, phages replicate by one of two ways, the lytic and the lysogenic cycles. In the lytic cycle, phages immediately after infection multiply, rapidly disrupting their host cells from within and then releasing the phage progeny that varies regularly between 10 and 1000 depending on the phage and the physiological status of the host cell. This process can be as short as 25-30 minutes in fast growing host bacteria. Phages that only 
follow the lytic cycle are known as virulent phages. In contrast, temperate, or lysogenic, phages can follow the lysogenic cycle, in which the genome of the temperate phage remains in the host bacteria, replicating along with it. At this stage, the phage is known as a prophage, which can be induced to follow the lytic cycle. Induction occurs either spontaneously or when stimulated by natural or anthropogenic inductors.

Bacteriophages can only replicate inside susceptible host bacteria. A given phage can only infect certain bacteria to the point that different strains of the same species differ in their susceptibility to phage attack (Muniesa et al., 2003; Thingstad et al., 2014). Receptor molecules on the surface of the bacteria mainly determine the host-specificity of phages. Phage receptors have been described in different parts of bacteria (capsule, cell wall, flagella and pili). Phages attached to the receptors located in the cell wall are typically known as somatic phages. Most of the known phages infect a limited number of strains. genome of either RNA or DNA surrounded by a protein coat named capsid. These particles are known as virions. Many phages also contain additional structures such as tails and spikes. Much less frequently, they contain lipids. In addition, they display a range of nucleic acid structures consisting of either double stranded (ds) or single stranded (ss) RNA or DNA, but never both. Phages may readily be grouped on the basis of a few gross characteristics including host range, morphology, nucleic acid, strategies of infection, morphogenesis, phylogeny, serology, sensitivity to physical and chemical agents, and dependence on properties of hosts and environment. The present classification adopted by the International Committee on Taxonomy of Viruses is mostly based in phage morphology and characteristics of the nucleic acid (Fauquet and Fargette, 2005). Phages of particular interest in water quality assessment are included into the seven families whose characteristics are summarized in Figure1.

In their extracellular phase, a phage consists of a
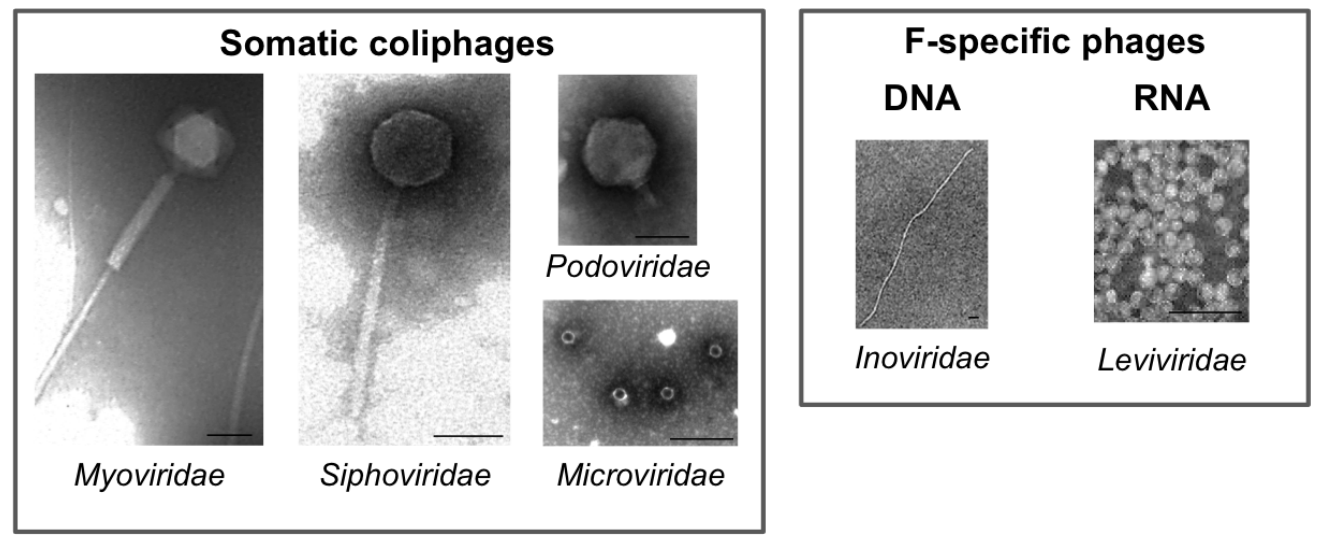

Figure 1. Most common morphological types in somatic coliphages and F-specific phages. Bar $50 \mathrm{~nm}$.

Owing to their simple structure and composition, virions persist quite successfully in the environment and are moderately resistant to natural and anthropogenic stressors (Grabow, 2001). It is likely that phages infecting bacteria indigenous to a given habitat are less persistent than their bacterial host (Ogunseitan et al., 1990), but also that phages survive better than host bacteria in habitats where they are aliens (Grabow, 2001). This will be the case of phages infecting enteric bacteria once outside the gut.

Typically, infectious phages are detected by their effects, mostly lysis, on the host bacteria that they infect. The most important factor in defining a method for the detection of a given phage or group of phages is the bacterial host strain. Easy methods to detect their presence or absence in a given volume of sample are available.
Phages are counted by direct quantitative plaque assays (Adams, 1959) (Figure 2). The plaque assay provides the results in plaque forming units (PFU). A plaque forming unit is an entity, usually a single virion but also e.g. a clump of virions that originates a single plaque. PFU are also denominated for example in the ISO standards, plaque forming particles (pfp). The presence of phages in a given volume of sample can also be determined by the qualitative presence-absence enrichment test (Adams, 1959) (Figure 3). Enrichment of multiple tube serial dilutions allows estimating numbers of phages by "quantal" methods, as for example the most probable number procedure. 


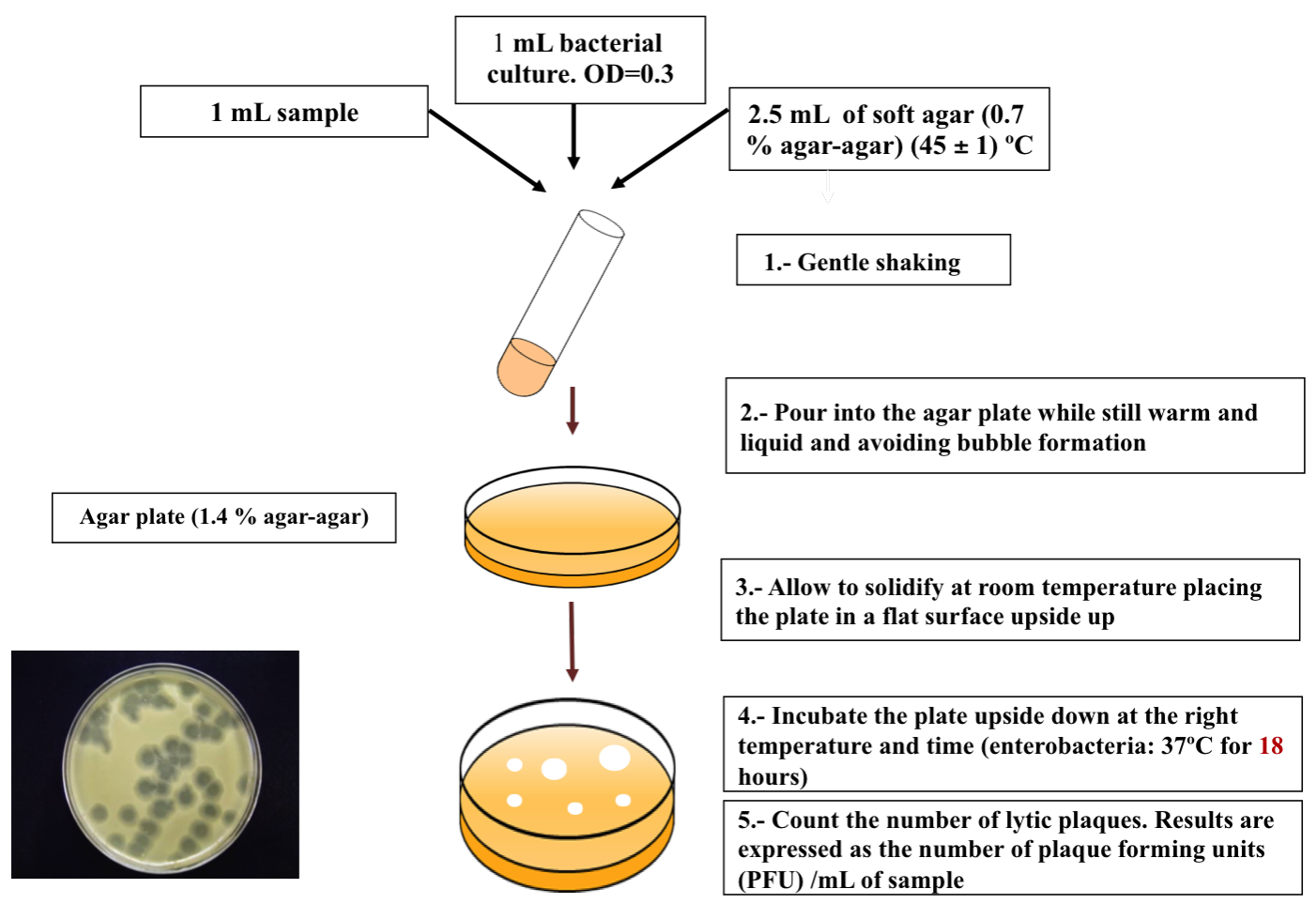

Figure 2. Bacteriophage enumeration by double agar layer method

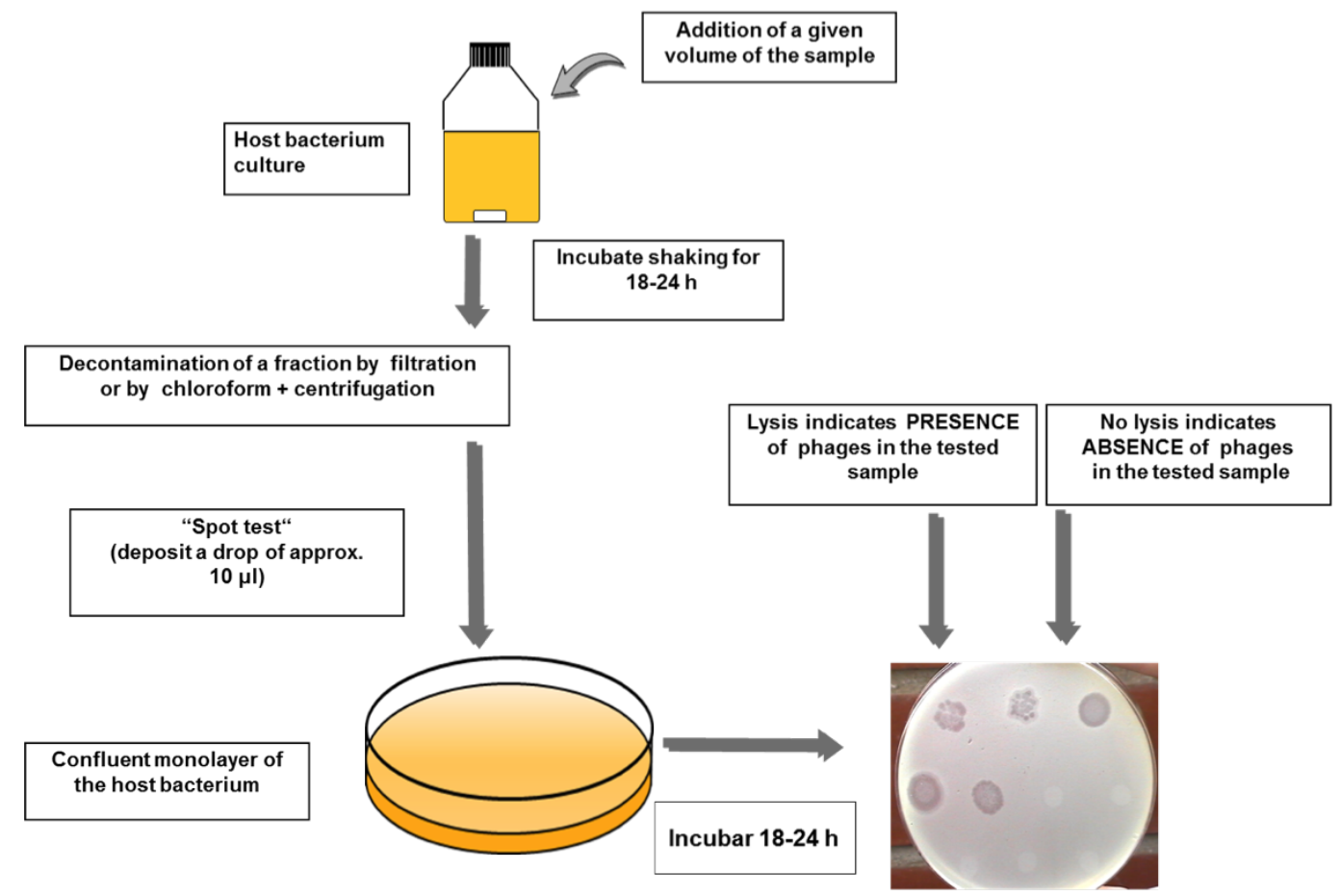

Figure 3. Detection of bacteriophage by the presence/absence method

Phages are used as faecal indicators to mimic enteric viruses better than any other group of indicators, and show moderate resistance and persistence in the water environment and through wastewater treatment (Armon and Kott, 1996; Grabow, 2001; IAWPRC Study group on health related water microbiology, 1991; Jofre, 2007). This is one of the reasons why different groups of phages infecting enteric bacteria have been proposed as either faecal or viral indicators. Phages used as indicators for faecal pollution and microbial source tracking, indicators as surrogated for pathogens (index) and indicators of public health risk have been assembled according to the detection 
methods. Coliphage are those viruses that infect the bacteria E.coli and somatic coliphages (IAWPRC Study group on health related water microbiology, 1991; Kott et al., 1974), F-specific RNA phages (Havelaar et al., 1990; IAWPRC Study group on health related water microbiology, 1991), and phages infecting Bacteroides (IAWPRC Study group on health related water microbiology, 1991; Tartera and Jofre, 1987) are those extensively studied regarding their potential as indicators of various aspects of water quality control. Reviews with a wide coverage of this potential application of phages as indexes, indicators or markers exist (Armon and Kott, 1996; Grabow, 2001; IAWPRC Study group on health related water microbiology, 1991; Jofre, 2007).

Other that the fact that they mimic various aspects of virus behaviour, the appeal of phages as indicators lies in the availability of feasible, fast and cost effective detection methods, and their abundance in wastewaters of human and animal origin. Moreover, samples can be kept at $4^{\circ} \mathrm{C}$ for at least 48 hour without any significant change in the numbers of infectious phages(Mendez et al., 2002); and small volume samples can be kept for months at $-20^{\circ} \mathrm{C}$ or $-80^{\circ} \mathrm{C}$ after the addition of $10 \% \mathrm{v} / \mathrm{v}$ glycerol (Mooijman et al., 2005). Reference suspensions of phages needed for quality assurance are easily prepared and conserved (Mendez et al., 2002; Mooijman et al., 2005). Finally, phenomena such as stress, injury or reactivation that frequently lead to misinterpretation of environmental data on bacterial indicators are not applicable to phages.

\subsection{Somatic Coliphages}

The term somatic coliphages defines the phages infecting Escherichia coli through the cell wall. Most known somatic coliphages found in municipal wastewater belong to the Myoviridae, Siphoviridae, Podoviridae and Microviridae families (Muniesa et al., 1999; RajalaMustonen and Heinonen-Tanski, 1994). Somatic coliphages most frequently used as model organisms are $\$ X 174$, PDR1, T2 and T7.

Somatic coliphages attach to the bacterial cell wall and may lyse the host cell in 25-30 min producing between 100 and 1000 phages per infected cell depending on both the phage and the physiological state of the cell. They produce plaques (Figure 2) of widely different size and morphology.

Host strains of somatic coliphages include Escherichia coli and related species such asShigellaspp and Klebsiella spp. Some of these may occur in pristine waters, so exceptionally somatic coliphages can find hosts in these environments. Several sorts of studies have shown many factors limit somatic coliphage replication in water environments. 1) The rather narrow host range of phages infecting the host strains used in the standardized methods (Muniesa et al., 2003). 2) The high densities of host bacteria and phages needed to ensure phage replication (Muniesa and Jofre, 2004; Wiggins and Alexander, 1985). 3) The presence in water of numerous background bacterial flora and particulate material that interferes with coliphage replication (Muniesa and Jofre, 2004; Wiggins and Alexander, 1985). 4) The metabolic activity of the host needed for phage replication is too low in the water environment (Cornax et al., 1991). 5) The envelope stress response that affects $E$. coli when released into the environment that could trigger responses diminishing phage infection (Perez-Rodriguez et al., 2011; Raivio, 2011). Moreover, the contribution of lysogenic induction to the presence of free coliphages is not noticeable. Hernandez-Delgado and Toranzos (Hernández-Delgado and Toranzos, 1995) have shown that neither sewage isolates nor laboratory phage strains replicated in pristine river water in a tropical area. These and other data reviewed (Jofre, 2009) strongly suggest that the contribution of somatic coliphages replicated outside the gut to the numbers of somatic coliphages detected in water environments is negligible.

Different host strains of $E$. coli as well as different assay media count different numbers and types of somatic coliphages (Havelaar et al., 1990; Muniesa et al., 1999). Consequently, from now on in this chapter preferential attention is given to data obtained with the standardized methods indicated.

\subsection{F-specific and F-specific RNA Bacteriophages}

F-specific bacteriophages, also termed sexual coliphages or male-specific phages infect bacteria through the sex pili, which are coded by the F plasmid first detected in E. coli K12. F-specific RNA phages, a subgroup of Fspecific phages consist of a simple capsid of cubic symmetry of 21-30 nm in diameter and contain a singlestranded RNA as the genome. The F-specific RNA phages group (Leviviridae) contains two genera (Levivirus and Allolevirus) and three minor unclassified groups (Fauquet and Fargette, 2005). Levivirus contains subgroups I and II, whereas Allolevirus contains subgroups III and IV. These four groups coincide with the serotypes first described by Furuse(Furuse, 1987). Posterior genomic characterization has allowed establishing that genogroups match with the serotypes (Beekwilder et al., 1996; Hsu et al., 1995), at least for practical purposes. Other F-specific phages are the rod-shaped DNA phages of the family Inoviridae (Fauquet and Fargette, 2005).

F-specific RNA phages used as model are MS2 and f2 belonging to genotype I, GA to genotype II, Q $\beta$ to genotype III and F1 to genotype IV. Sero and genogrouping of RNA F-specific phages has been used to differentiate subgroups in waters receiving faecal wastes, and the study of subgroups distribution may contribute to source tracking of faecal pollution. This is because groups I and IV are the predominant in waters contaminated with animal faecal residues whereas groups II and III are mostly associated with human pollution (Jofre et al., 2011). Long and collaborators have also studied whether typing of F-specific DNA phages could be useful for microbial source tracking (MST), but results seem to indicate that they are not (Long et al., 2005)

The F plasmid is transferable to a wide range of Gramnegative bacteria and so F-specific phages may have several hosts. Yet, it is thought that their main natural host is E. coli. The sexual pili are not synthesized below $32^{\circ} \mathrm{C}$. In 
spite of the temperature conditioned production of sexual pili, necessary for phage replication, conflicting reports on replication of F-specific phages in wastewater and groundwater exist (Havelaar and Pot-Hogeboom, 1988). Nevertheless, Woody and Cliver reviewed conditions affecting F-specific RNA phage replication other than pili formation in the host bacteria, and concluded that replication outside the gut cannot be excluded but also that it is very improbable (Woody and Cliver, 1997). Therefore, the influence of replication outside the gut in the numbers of these phages in the environment can be considered as negligible.

The infectious process of F-specific RNA phages is inhibited by the presence of RNase in the assay medium, which can be used to distinguish between the F-specific RNA phages and the other phages than can infect the host bacteria. These are the rod-shaped F-specific DNA phages of the family Inoviridae, which also infect the host cell through the sex pili as well as the somatic phages that can infect the bacterial host used.

\subsection{Bacteriophages Infecting Bacteroides}

Bacteriophages infecting strains of several species of Bacteroideshave been detected in faeces and wastewater contaminated with faecal wastes (Jofre et al., 2014). Replication of phages infecting Bacteroidesoutside of the gut of warm-blooded animals is even more unlikely than in the case of the coliphages referred to in previous sections. This is due to the additional stringent requirements of the host strain regarding anaerobiosis and nutrients that are unlikely to occur and coincide in natural water environments (Tartera and Jofre, 1987).

Phages infecting different Bacteroides species described so far are all tailed and the vast majority of them have the morphology corresponding to the family Siphoviridae (McLaughlin and Rose, 2006; Queralt et al., 2003; Tartera and Jofre, 1987). As well, the genome sequence of the few Bacteroidesinfecting phages studied corresponds to that of Siphoviridae (Hawkins et al., 2008; Ogilvie et al., 2013).

Phages infecting Bacteroides seem to infect the host through the cell wall and therefore are somatic phages(Puig et al., 2001) yet most phages infecting Bacteroideshave a quite narrow host range (Cooper et al., 1984; Kory and Booth, 1986; Tartera and Jofre, 1987).

In addition to the narrow host range of phages, strains ofBacteroides spp. differ in their ability to recover phages in faecal material, wastewaters and wastewater contaminated waters (Payán et al., 2005; Puig et al., 1999). Bacteroides strains differ also in their capability to detect phages in the faeces of different animal species, including humans, and hence in their ability to determine the origin of faecal contamination in a given sample. Some strains of $B$. fragilis, such as RYC2056 and VPI3625, detect phages both in human and non-human faecal wastes (Blanch et al., 2006; Kator and Rhodes, 1992; Puig et al., 1999). Others are able to discern the faecal source. Those detecting higher numbers of phages are reported in Table 1. However, this source specificity is not absolute and though seldom, host strains reported in Table 1 detect very low numbers of phages in the non-corresponding sources. The method proposed by Payán et al. (2005) allows isolating hosts appropriate for a given host and a given geographical area with reasonable success. The total cost associated with each attempt to isolate new strains did not exceed 1,000 euros including consumables and labour (approximately 1 month).

Table 1. Host strains of Bacteroides discerning faecal sources and country of isolation

\begin{tabular}{|c|c|c|c|c|c|c|}
\hline Area & Host strain & Sample Type & $\begin{array}{l}\text { Source of } \\
\text { origin }\end{array}$ & $\begin{array}{l}\text { Percent } \\
\text { Positive }\end{array}$ & $\begin{array}{c}\text { Concentration } \\
\text { Average } \\
\text { (range) } \\
\text { PFU/100 mL at source }{ }^{\mathrm{a}}\end{array}$ & Reference \\
\hline Colombia & B. fragilis $\mathrm{HB} 13$ & $\begin{array}{c}\text { Municipal } \\
\text { wastewater }\end{array}$ & Human & $100 \%$ & $1 E+04$ to $1 E+05$ & $\begin{array}{l}\text { Payan et al., } \\
2005\end{array}$ \\
\hline Colombia & B. fragilis CA8 & $\begin{array}{c}\text { Municipal } \\
\text { wastewater }\end{array}$ & Human & $100 \%$ & $1 \mathrm{E}+02$ to $1 \mathrm{E}+04$ & $\begin{array}{l}\text { Venegas et } \\
\text { al., } 2015^{\mathrm{b}}\end{array}$ \\
\hline Spain & $\begin{array}{l}\text { B. fragilis } \\
\text { HSP } 40\end{array}$ & Clinical sample & Human & $100 \%$ & $1 \mathrm{E}+03$ to $1 \mathrm{E}+04$ & $\begin{array}{l}\text { Tartera and } \\
\text { Jofre, } 1987\end{array}$ \\
\hline Spain & $\begin{array}{c}B . \\
\text { thetaiotaomicron } \\
\text { GA17 }\end{array}$ & $\begin{array}{c}\text { Municipal } \\
\text { wastewater }\end{array}$ & Human & $100 \%$ & $1 \mathrm{E}+04$ to $1 \mathrm{E}+5.5$ & $\begin{array}{l}\text { Payan et al., } \\
2005\end{array}$ \\
\hline Spain & B. fragilis PG76 & $\begin{array}{c}\text { Swine } \\
\text { slaughterhouse }\end{array}$ & Pig & $100 \%$ & $1 \mathrm{E}+05$ to $1 \mathrm{E}+06$ & $\begin{array}{l}\text { Gómez-Doñate } \\
\text { et al., 2011 }\end{array}$ \\
\hline Spain & $\begin{array}{l}\text { B. fragilis } \\
\text { PG1226 }\end{array}$ & $\begin{array}{c}\text { Swine } \\
\text { slaughterhouse }\end{array}$ & Pigs & $100 \%$ & $1 \mathrm{E}+05$ to $1 \mathrm{E}+06$ & $\begin{array}{l}\text { Gómez-Doñate } \\
\text { et al., 2011 }\end{array}$ \\
\hline Spain & $\begin{array}{c}B . \\
\text { thetaiotaomicron } \\
\text { CW18 }\end{array}$ & $\begin{array}{c}\text { Cattle } \\
\text { slaughterhouse }\end{array}$ & Cows & $70 \%$ & $1 \mathrm{E}+03$ to $1 \mathrm{E}+04$ & $\begin{array}{l}\text { Gómez-Doñate } \\
\text { et al., 2011 }\end{array}$ \\
\hline
\end{tabular}




\begin{tabular}{|c|c|c|c|c|c|c|}
\hline Area & Host strain & Sample Type & $\begin{array}{l}\text { Source of } \\
\text { origin }\end{array}$ & $\begin{array}{l}\text { Percent } \\
\text { Positive }\end{array}$ & $\begin{array}{c}\begin{array}{c}\text { Concentration } \\
\text { Average } \\
\text { (range) }\end{array} \\
\text { PFU/100 } \mathbf{~ m L} \text { at source }^{\mathrm{a}}\end{array}$ & Reference \\
\hline Spain & B. fragilis PL122 & $\begin{array}{c}\text { Poultry } \\
\text { slaughterhouse }\end{array}$ & Poultry & $82 \%$ & $1 \mathrm{E}+03$ to $1 \mathrm{E}+04$ & $\begin{array}{c}\text { Gómez-Doñate } \\
\text { et al., 2011 }\end{array}$ \\
\hline Switzerland & $\begin{array}{l}\text { B. fragilis } \\
\text { ARABA } 84\end{array}$ & $\begin{array}{c}\text { Municipal } \\
\text { wastewater }\end{array}$ & Human & $100 \%$ & $1 \mathrm{E}+03$ to $1 \mathrm{E}+04$ & $\begin{array}{l}\text { Wicki et al., } \\
2011^{\mathrm{b}}\end{array}$ \\
\hline Switzerland & $\begin{array}{c}\text { B. fragilis } \\
\text { ARABA KBA60 }\end{array}$ & Slaughterhouse & $\begin{array}{l}\text { Cattle and } \\
\text { horses }\end{array}$ & $67 \%$ & $1 E+02$ & $\begin{array}{l}\text { Wicki et al., } \\
2011^{\mathrm{b}}\end{array}$ \\
\hline $\begin{array}{l}\text { United } \\
\text { Kingdom } \\
\text { (UK) }\end{array}$ & B. fragilis GB124 & $\begin{array}{c}\text { Municipal } \\
\text { wastewater }\end{array}$ & Human & $100 \%$ & $1 \mathrm{E}+04$ to $1 \mathrm{E}+5.5$ & $\begin{array}{l}\text { Payan et al., } \\
2005\end{array}$ \\
\hline
\end{tabular}

${ }^{a}$ Municipal wastewater or slaughterhouse (specific) wastewater; ${ }^{b}$ Isolated according to the method described by Payán et al. (2005)

Strains RYC2056, GA17, GB124 and PG2166 were selected as those giving higher and more consistent counts in the matching wastewaters and are those that will be further discussed.

\subsection{Detection and Concentration Methods}

Generally phage are assayed without concentration directly with their respective host as plaque assay or in a presence absence format.

\subsection{Somatic Coliphages}

Methods for the detection and enumeration of somatic coliphages have been standardized by ISO 10705-2 (Anonymous, 2000), USEPA 1601 and 1602 (EPA, 2001a; 2001b)and Standard Methods (Rice, 2012), (Table 2).

Table 2. Standardized methods for the detection of somatic coliphages

\begin{tabular}{|c|c|c|c|c|c|c|c|c|}
\hline $\begin{array}{c}\text { Target } \\
\text { indicator }\end{array}$ & $\begin{array}{l}\text { Host } \\
\text { strain }\end{array}$ & $\begin{array}{l}\text { Name of } \\
\text { assay }\end{array}$ & $\begin{array}{c}\text { Type of } \\
\text { assay } \\
\text { (results) }\end{array}$ & $\begin{array}{l}\text { Expression of } \\
\text { results }\end{array}$ & $\begin{array}{c}\text { Time } \\
\text { for } \\
\text { results } \\
\end{array}$ & $\begin{array}{c}\text { Control and } \\
\text { Reference } \\
\text { materials } \\
\end{array}$ & $\begin{array}{c}\text { Standard } \\
\text { method }\end{array}$ & Reference \\
\hline $\begin{array}{l}\text { Somatic } \\
\text { coliphages }^{\mathrm{a}, \mathrm{b}, \mathrm{c}}\end{array}$ & $\begin{array}{l}\text { E. coli } \\
\text { WG5 }\end{array}$ & $\begin{array}{c}\text { Plaque assay } \\
\text { (double agar } \\
\text { layer- DAL) }\end{array}$ & Quantitative & $\begin{array}{l}\text { Plaque forming } \\
\text { units (PFU)/ } \\
\text { given volume }\end{array}$ & 6 hours & $\begin{array}{l}\text { Quality control } \\
\text { included in the } \\
\text { standard } \\
\text { method. Not } \\
\text { commercial } \\
\text { reference } \\
\text { materials, but } \\
\text { easy to prepare }\end{array}$ & $\begin{array}{c}\text { ISO } \\
10705-2\end{array}$ & $\begin{array}{c}\text { Anonymous, } \\
2000\end{array}$ \\
\hline $\begin{array}{l}\text { Somatic } \\
\text { coliphages }\end{array}$ & $\begin{array}{l}\text { E. coli } \\
\text { WG5 }\end{array}$ & $\begin{array}{c}\text { Presence/ } \\
\text { absence. Spot } \\
\text { test after } \\
\text { enrichment }\end{array}$ & Qualitative & $\begin{array}{l}\text { Presence or } \\
\text { absence in a } \\
\text { given volume. } \\
\text { Can be adapted } \\
\text { to the MPN }\end{array}$ & $\begin{array}{c}24 \\
\text { hours }\end{array}$ & $\begin{array}{l}\text { Quality control } \\
\text { included in the } \\
\text { standard } \\
\text { method. Not } \\
\text { commercial } \\
\text { reference } \\
\text { materials, but } \\
\text { easy to prepare }\end{array}$ & $\begin{array}{c}\text { ISO } \\
10705-2\end{array}$ & $\begin{array}{c}\text { Anonymous, } \\
2000\end{array}$ \\
\hline $\begin{array}{l}\text { Somatic } \\
\text { coliphages }\end{array}$ & $\begin{array}{l}\text { E. coli } \\
\text { CN13 }\end{array}$ & $\begin{array}{c}\text { Plaque assay } \\
\text { (single agar } \\
\text { layer-SAL) }\end{array}$ & Quantitative & $\begin{array}{l}\text { Plaque forming } \\
\text { units (PFU) per } \\
\text { a given volume }\end{array}$ & 6 hours & $\begin{array}{c}\text { Not commercial } \\
\text { reference } \\
\text { materials, but } \\
\text { easy to prepare }\end{array}$ & $\begin{array}{l}\text { USEPA } \\
\text { METHOD } \\
1602\end{array}$ & $\begin{array}{l}\text { U.S. EPA, } \\
2001 \mathrm{~b}\end{array}$ \\
\hline $\begin{array}{l}\text { Somatic } \\
\text { coliphages }\end{array}$ & $\begin{array}{l}\text { E. coli } \\
\text { CN13 }\end{array}$ & $\begin{array}{l}\text { Presence/ } \\
\text { absence }\end{array}$ & Qualitative & $\begin{array}{l}\text { Presence or } \\
\text { absence in a } \\
\text { given volume. } \\
\text { Can be adapted } \\
\text { to the MPN }\end{array}$ & $\begin{array}{c}24 \\
\text { hours }\end{array}$ & $\begin{array}{l}\text { Not commercial } \\
\text { reference } \\
\text { materials, but } \\
\text { easy to prepare }\end{array}$ & $\begin{array}{l}\text { USEPA } \\
\text { METHOD } \\
1601\end{array}$ & $\begin{array}{l}\text { U.S. EPA, } \\
\text { 2001a }\end{array}$ \\
\hline
\end{tabular}




\begin{tabular}{|c|c|c|c|c|c|c|c|c|}
\hline $\begin{array}{c}\text { Target } \\
\text { indicator }\end{array}$ & $\begin{array}{l}\text { Host } \\
\text { strain }\end{array}$ & $\begin{array}{l}\text { Name of } \\
\text { assay }\end{array}$ & $\begin{array}{c}\text { Type of } \\
\text { assay } \\
\text { (results) }\end{array}$ & $\begin{array}{l}\text { Expression of } \\
\text { results }\end{array}$ & $\begin{array}{c}\text { Time } \\
\text { for } \\
\text { results }\end{array}$ & $\begin{array}{c}\text { Control and } \\
\text { Reference } \\
\text { materials }\end{array}$ & $\begin{array}{l}\text { Standard } \\
\text { method }\end{array}$ & Reference \\
\hline $\begin{array}{l}\text { Somatic } \\
\text { coliphages }\end{array}$ & $\begin{array}{l}\text { E. coli } \\
\text { C }\end{array}$ & $\begin{array}{c}\text { Plaque assay } \\
\text { (double agar } \\
\text { layer- DAL) }\end{array}$ & Quantitative & $\begin{array}{l}\text { Plaque forming } \\
\text { units (PFU) per } \\
\text { a given volume }\end{array}$ & 6 hours & $\begin{array}{c}\text { Not commercial } \\
\text { reference } \\
\text { materials, but } \\
\text { easy to prepare }\end{array}$ & $\begin{array}{l}\text { Standard } \\
\text { Method } \\
\text { 9224B }\end{array}$ & $\begin{array}{c}\text { Green, } \\
2000\end{array}$ \\
\hline
\end{tabular}

${ }^{a}$ Detection principle is replication of phages in host strain; ${ }^{b}$ Pre-treatment not needed for water; extraction from solids; 'Volume tested adjustable

Other than some details on media and assay conditions, the three methods use E. coli $\mathrm{C}$ as host strain. These are either E. coli ATCC 13706(Rice, 2012)or their nalidixic acid resistant clones E. coli CN13 (ATCC 700609) used in the USEPA 1601 and 1602 methods, or E. coli CN, more frequently referred as WG5, (ATCC 700078) used in the ISO 10705-2 method. Hosts resistant to nalidixic acid were introduced to minimize the growth of background bacteria that frequently interferes in the correct visualization of plaques in the plaque assay test. This allows quantifying phages in samples avoiding filtration of the sample to eliminate the background bacteria. Of course, filtration through $0.22 \mu \mathrm{m}$ non-protein binding membrane filters such as those of polyvinylidene fluoride or polyether sulfone can also be applied to eliminate background bacteria present in the sample. In contrast, membrane filters of mixed cellulose and acetate membranes will adsorb and consequently retain phages. Strains ATCC13706, CN13 and WG5 detect similar numbers of phages in water matrixes when using the same method (Grabow et al., 1993; Guzmán et al., 2008). Other, non C E. coli host strains count lesser numbers of somatic coliphages (Grabow et al., 1993; Havelaar and Hogeboom, 1983; Stetler, 1984). One of these strains used frequently (Rose et al., 2004) is E. coli C3000 (ATCC 15597) that is an Hfr strain derived from $\mathrm{K} 12$, which is used to count simultaneously somatic coliphages and F-specific phages. Strain E. coli CB390 was tailored to detect the same numbers of somatic coliphages as WG5 and as many Fspecific phages as host strains used in standardized procedures (Guzmán et al., 2008)and it detects similar number of F-specific phages but more somatic coliphages than C3000.

ISO-10705-2 (Anonymous, 2000) includes both the double agar layer (DAL) plaque assay method for the quantification of PFU (Figure 2) and the presence/absence test (Figure 3) than can also be adapted to a more probable number format. A simplified version of these methods can be found in Havelaar and Hogeboom (Havelaar and Hogeboom, 1983). Mooijman et al. (2005)proved that the implementation of the ISO standard method is feasible in routine microbiology laboratories without previous experience in phages.

USEPA Method 1601 (U.S. EPA, 2001a)deals with the presence absence method and EPA method 1602 (U.S. EPA, $2001 \mathrm{~b}$ )with the single agar layer (SAL) plaque assay. A simplified version of these methods can be read in USEPA (U.S. EPA, 2001c). USEPA (U.S. EPA, 2003a, 2003b)has carried out interlaboratory validation tests of methods 1601 and 1602. A double agar layer (DAL) plaque assay method with strain $\mathrm{C}$ as the host is described in the 22nd edition of Standard Methods (Rice, 2012).

Results using these plaque assay methods can be obtained in 6 hours, though the habitual period of assay is 18 hours.

Detection and enumeration of somatic coliphages by the standardized methods is quite cost effective. The cost in material, media, reagents and labour is similar to the one for detection of faecal coliforms or E. coli. It can be done in routine microbiology laboratories. Additionally, the ISO procedure includes optional steps for laboratories with limited equipment.

Additionally to the host strains there are minor differences in the media between the standardized procedures. USEPA and ISO methods count similar numbers of somatic coliphages (Guzmán et al., 2008). As well, the present Standard Methods method is supposed to provide similar counts than ISO and USEPA. In contrast, the Standard Methods procedure described in previous editions has been reported to perform poorly (Green, 2000).

Regarding fast methods, no procedures based in serologic detection or PCR have been described that are applicable to the detection of the group somatic coliphages in waters. The diversity of phages included in this group makes this approach complex. In contrast, FAST PHAGE, which is applicable to the methods based on presence/absence of USEPA and ISO, has been described by Salter and Durbin (Salter and Durbin, 2012). This method is based on a rapid extracellular beta-galactosidase enzyme release and detection during the coliphage induced lysis.

Volumes of sample tested as described in the methods can be scaled up keeping the proportions of the mixtures of medium, host suspension and sample and using different size Petri dishes accordingly.

\subsection{F-specific and F-specific RNA Bacteriophages}

Host strains to detect sexual coliphages must produce sexual pili encoded by the F-plasmid. Hfr E. coli strains 
such as C3000 (ATCC 15597) were firstly used for this purpose, but these strains also detect high numbers of somatic coliphages. Later, strains Escherichia coli HS(E.coli Famp, ATCC 700891)(Debartolomeis and Cabelli, 1991)and Salmonella entericaserovar typhimurium (most frequently reported as Salmonella typhimurium) WG49 (NCTC 12484)(Havelaar and Hogeboom, 1984)were tailored to detect mainly F-specific phages, though both still detect a very small proportion of somatic phages infecting either E. coli or S. typhimurium. Strains HS and WG49 were selected as host strains in the standardized methods mentioned later on. The phages detected by these strains are counted as sexual or F-specific coliphages. The number of F-specific RNA phages is the difference between the numbers of phages counted in the absence and in the presence of RNase in the assay medium. More than 90-95 $\%$ of the phages detected in sewage by strains HS and WG49 are F-specific RNA phages (Debartolomeis and Cabelli, 1991; Havelaar and Hogeboom, 1984), but this percentage may be lower in receiving waters and treated wastewaters. Counts achieved by strains HS and WG49 are similar (Chung et al., 1996; Grabow et al., 1993). Because of the genetic markers (resistance to ampicillin and capacity to use lactose), the stability (and re-selection) of strain WG49 is easier to check than that of strain HS that has no explicit genetic markers.

Standardized methods for the detection and enumeration of both F-specific and F-specific RNA phages exist (Table 3). The ISO-10705-1 (Anonymous, 1995)standard method for the detection and enumeration of phages endorse Salmonella typhimurium WG49 as host strain and include a step with RNase in the assay medium. Consequently, it detects both F-specific and F-specific RNA phages. The ISO standard includes both the double layer plaque assay method and the presence-absence method. A simplified version can be found in Havelaar and Hogeboom (1984)and Standard Methods (Rice, 2012). Mooijman et al. (2005) proved that the implementation of the ISO standard method is feasible in routine microbiology laboratories without previous experience in phages.

Table 3. Methods for the detection of F-specific phages, F-specific RNA phages and subgroups of F-specific RNA phages

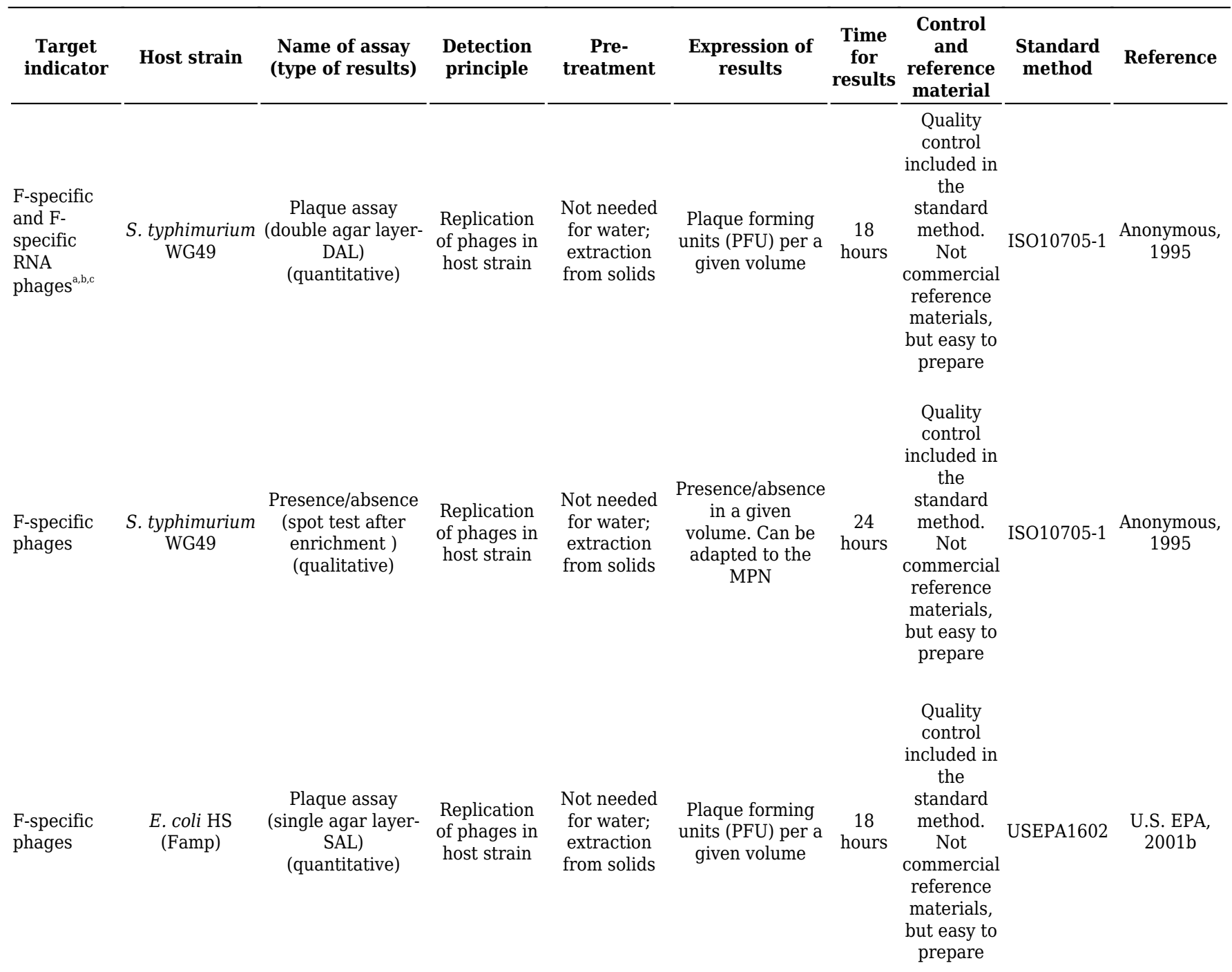




\begin{tabular}{|c|c|c|c|c|c|c|c|c|c|}
\hline $\begin{array}{c}\text { Target } \\
\text { indicator }\end{array}$ & Host strain & $\begin{array}{l}\text { Name of assay } \\
\text { (type of results) }\end{array}$ & $\begin{array}{l}\text { Detection } \\
\text { principle }\end{array}$ & $\begin{array}{c}\text { Pre- } \\
\text { treatment }\end{array}$ & $\begin{array}{l}\text { Expression of } \\
\text { results }\end{array}$ & $\begin{array}{l}\text { Time } \\
\text { for } \\
\text { results }\end{array}$ & $\begin{array}{l}\text { Control } \\
\text { and } \\
\text { reference } \\
\text { material } \\
\end{array}$ & $\begin{array}{l}\text { Standard } \\
\text { method }\end{array}$ & Reference \\
\hline $\begin{array}{l}\text { F-specific } \\
\text { phages }\end{array}$ & $\begin{array}{l}\text { E. coli HS } \\
\text { (Famp) }\end{array}$ & $\begin{array}{l}\text { Presence/ absence } \\
\text { (spot test after } \\
\text { enrichment) } \\
\text { (qualitative) }\end{array}$ & $\begin{array}{c}\text { Replication } \\
\text { of phages in } \\
\text { host strain }\end{array}$ & $\begin{array}{l}\text { Not needed } \\
\text { for water; } \\
\text { extraction } \\
\text { from solids }\end{array}$ & $\begin{array}{l}\text { Plaque forming } \\
\text { units (PFU) per a } \\
\text { given volume }\end{array}$ & $\begin{array}{c}24 \\
\text { hours }\end{array}$ & $\begin{array}{l}\text { Quality } \\
\text { control } \\
\text { included in } \\
\text { the } \\
\text { standard } \\
\text { method. } \\
\text { Not } \\
\text { commercial } \\
\text { reference } \\
\text { materials, } \\
\text { but easy to } \\
\text { prepare }\end{array}$ & $\begin{array}{l}\text { USEPA } \\
1601\end{array}$ & $\begin{array}{l}\text { U.S. EPA, } \\
2001 \mathrm{a}\end{array}$ \\
\hline $\begin{array}{l}\text { F-specific } \\
\text { RNA phages } \\
\text { subgroups } \\
\text { (genotyping) }\end{array}$ & $\begin{array}{l}\text { S. typhimurium } \\
\text { WG49 or E. } \\
\text { coli HS (Famp) }\end{array}$ & $\begin{array}{l}\text { Plaque (obtained } \\
\text { by either DAL or } \\
\text { SAL) hybridization } \\
\text { (quantitative) }\end{array}$ & $\begin{array}{l}\text { Replication } \\
\text { of phages in } \\
\text { host strain } \\
\text { followed by } \\
\text { plaque } \\
\text { hybridization } \\
\text { by specific } \\
\text { probes for } \\
\text { each } \\
\text { subgroup }\end{array}$ & $\begin{array}{l}\text { Not needed } \\
\text { for water; } \\
\text { extraction } \\
\text { from solids }\end{array}$ & $\begin{array}{l}\text { Percentages of } \\
\text { plaques } \\
\text { hybridizing with } \\
\text { each probe }\end{array}$ & $\begin{array}{c}48 \\
\text { hours }\end{array}$ & $\begin{array}{c}\text { No } \\
\text { reference } \\
\text { material } \\
\text { available. } \\
\text { But control } \\
\text { with model } \\
\text { phages are } \\
\text { easy to } \\
\text { prepare }\end{array}$ & $\begin{array}{l}\text { No } \\
\text { standard } \\
\text { method } \\
\text { available }\end{array}$ & $\begin{array}{l}\text { (Anonymous, } \\
\text { 1995; U.S. } \\
\text { EPA, 2001b) } \\
\text { for plaque } \\
\text { assay and } \\
\text { (Schaper } \\
\text { and Jofre, } \\
\text { 2000) for } \\
\text { plaque } \\
\text { hybridization }\end{array}$ \\
\hline $\begin{array}{l}\text { F-specific } \\
\text { RNA phages } \\
\text { subgroups } \\
\text { (genotyping) }\end{array}$ & $\begin{array}{l}\text { S. typhimurium } \\
\text { WG49 or E. } \\
\text { coli HS (Famp) }\end{array}$ & $\begin{array}{l}\text { Plaque (obtained } \\
\text { by either DAL or } \\
\text { SAL) genotyping } \\
\text { by RT-PCR } \\
\text { (quantitative) }\end{array}$ & $\begin{array}{l}\text { Replication } \\
\text { of phages in } \\
\text { host strain } \\
\text { followed by } \\
\text { qRT-PCR of } \\
\text { phages in } \\
\text { the plaques }\end{array}$ & $\begin{array}{l}\text { Not needed } \\
\text { for water; } \\
\text { extraction } \\
\text { from solids }\end{array}$ & $\begin{array}{l}\text { Percentages of } \\
\text { plaques that } \\
\text { react to pairs of } \\
\text { primers } \\
\text { corresponding to } \\
\text { each subgroup }\end{array}$ & $\begin{array}{l}26-28 \\
\text { hours }\end{array}$ & $\begin{array}{c}\text { No } \\
\text { reference } \\
\text { material } \\
\text { available. } \\
\text { But control } \\
\text { with model } \\
\text { phages are } \\
\text { easy to } \\
\text { prepare }\end{array}$ & $\begin{array}{l}\text { No } \\
\text { standard } \\
\text { method } \\
\text { available }\end{array}$ & $\begin{array}{c}\text { (Anonymous, } \\
\text { 1995; U.S. } \\
\text { EPA, 2001b) } \\
\text { for plaque } \\
\text { assay and } \\
\text { (Kirs and } \\
\text { Smith, 2007; } \\
\text { Ogorzaly } \\
\text { and Gantzer, } \\
\text { 2006) for } \\
\text { qRT-PCR }\end{array}$ \\
\hline $\begin{array}{l}\text { F-specific } \\
\text { RNA phages } \\
\text { subgroups } \\
\text { (serotyping) }\end{array}$ & $\begin{array}{l}\text { S. typhimurium } \\
\text { WG49 or E. } \\
\text { coli HS (Famp) }\end{array}$ & $\begin{array}{c}\text { Culture latex } \\
\text { agglutination and } \\
\text { typing. Combines a } \\
\text { two-step } \\
\text { enrichment } \\
\text { process } \\
\text { (presence/absence) } \\
\text { and latex } \\
\text { agglutination } \\
\text { serotyping } \\
\text { (quantitative or } \\
\text { qualitative) }\end{array}$ & $\begin{array}{l}\text { Replication } \\
\text { of phages in } \\
\text { host strain } \\
\text { followed by } \\
\text { agglutination } \\
\text { with specific } \\
\text { antibodies }\end{array}$ & $\begin{array}{l}\text { Not needed } \\
\text { for water; } \\
\text { extraction } \\
\text { from solids }\end{array}$ & $\begin{array}{l}\text { Percentages of } \\
\text { plaques } \\
\text { agglutinating } \\
\text { with each } \\
\text { antibody }\end{array}$ & $\begin{array}{c}5-24 \\
\text { hours }\end{array}$ & $\begin{array}{c}\text { No } \\
\text { reference } \\
\text { material } \\
\text { available. } \\
\text { But control } \\
\text { with model } \\
\text { phages are } \\
\text { easy to } \\
\text { prepare }\end{array}$ & $\begin{array}{l}\text { No } \\
\text { standard } \\
\text { method } \\
\text { available }\end{array}$ & $\begin{array}{l}\text { (Anonymous, } \\
\text { 1995; U.S. } \\
\text { EPA, 2001b) } \\
\text { and for } \\
\text { enrichment; } \\
\text { (Love and } \\
\text { Sobsey, } \\
\text { 2007) }\end{array}$ \\
\hline $\begin{array}{l}\text { F-specific } \\
\text { RNA phages } \\
\text { subgroups } \\
\text { (genotyping) }\end{array}$ & Not needed & $\begin{array}{l}\text { Multiplex qRT-PCR } \\
\text { (qualitative) }\end{array}$ & $\begin{array}{l}\text { Amplification } \\
\text { of fragments } \\
\text { of genome } \\
\text { present in } \\
\text { the sample }\end{array}$ & $\begin{array}{l}\text { Concentration } \\
\text { from water; } \\
\text { extraction } \\
\text { from solids }\end{array}$ & $\begin{array}{l}\text { Genome copies in } \\
\text { the sample }\end{array}$ & $\begin{array}{c}\text { 3-4 } \\
\text { hours }\end{array}$ & $\begin{array}{c}\text { No } \\
\text { reference } \\
\text { material } \\
\text { available. } \\
\text { But control } \\
\text { with model } \\
\text { phages are } \\
\text { easy to } \\
\text { prepare }\end{array}$ & $\begin{array}{l}\text { No } \\
\text { standard } \\
\text { method } \\
\text { available }\end{array}$ & $\begin{array}{c}\text { Wolf et al., } \\
2010\end{array}$ \\
\hline
\end{tabular}

${ }^{a}$ Detection principle is replication of phages in host strain; ${ }^{\mathrm{b}}$ Pretreatment not needed for water; extraction from solids; ${ }^{\mathrm{c}}$ Volume tested adjustable

EPA Method 1601 (U.S. EPA, 2001a)standard deals with the presence-absence method and EPA method 1602 (U.S. EPA, 2001b)with the single layer plaque assay (SAL) for the detection of F-specific phages. These methods use E.coli Famp as host strain. A simplified version can be found in USEPA (U.S. EPA, 2001c)and Standard Methods (Rice, 2012). USEPA (U.S. EPA, 2003a, 2003b)has carried out interlaboratory validation tests on methods 1601 and 1602.

Results using both plaque assay methods can be obtained in 18 hours.

The cost in material, media and reagents and labour for the detection of F-specific coliphages is similar to that for the detection of somatic coliphages. The cost for the detection of F-specific RNA phages is 10-15 \% higher because of the need of RNase and the double number of plates. It can be done in routine microbiology laboratories.

Using any one of the methods, volumes tested as 
described in the basic standardized methods can be scaled up keeping the proportions of the mixtures of assay media and sample.

Molecular methods are available. However, they are for a specific phage or for a subgroup, not for the full group. The sum of genome copies (GC) obtained by RT-qPCR (Reverse transcription-quantitative polymerase chain reaction) of the different subgroups accounts for all Fspecific RNA phages. These methods are referred to later on in the section on F-specific RNA phages for microbial source tracking section.

Different procedures for detecting F-RNA phage subgroups are available, some based on serological recognition and others based on nucleic acid sequence recognition (Table 3).

Among the first group of methods, there are the "neutralization" method first described (Furuse, 1987)and the culture latex agglutination and typing test (Love and Sobsey, 2007). The latex agglutination method is fast and can be applied in situ, though it may require preenrichment. However, nowadays accessibility of specific antisera is less practical than the availability of nucleic acid probes and primers.

Methods based either on plaque hybridization with specific probes and those based on RT-PCR seem more realistic. Nowadays RT-qPCR is commonly used.

Plaque hybridization is applied on plaques grown by either the ISO-10705-1 or the USEPA 1602 standards (Beekwilder et al., 1996; Hsu et al., 1995; Schaper and Jofre, 2000). This method implies the transfer of the plaques to four different $\mathrm{N}^{+}$hybond membranes and posterior hybridization of each membrane with a probe specific for each one of the 4 subgroups. It has the advantage that many plaques can be studied at once.

Reverse transcription-polymerase chain reaction (RTPCR) assays have been developed for MS2, the prototypical F-RNA phage of subgroup I (O'Connell et al., 2006), the different genogroups (Ogorzaly and Gantzer, 2006)and multiplex for all subgroups (Friedman et al., 2009; Kirs and Smith, 2007; Wolf et al., 2010). RT-PCR can be applied either to phages recovered from plaques obtained by the plaque assay method or directly (RT-qPCR) to determine the number of genome copies (GC) present in a given sample. The first approach allows apportioning the subgroups of the infectious phages, whereas the second does not provide insight in the infectiousness of the phages, but results can be obtained within a few hours.

The actual concentrations of phages belonging to each one of the subgroups in a given sample can be estimated by applying the percentages corresponding to each group to the concentration of F-specific RNA phages.

In contrast, direct RT-qPCR can provide directly the real numbers of GC. The numbers of GC usually exceed those of infectious phages determined by plaque assay. This difference is actually observed in faeces, and even varies from sample to sample (Hartard et al., 2015). In raw human and animal wastewaters, the GC numbers exceed the values of infectious phages by between 1.5 and $2.6 \log _{10}$ units. However, this is not always the case, probably because of poor efficiency of the RT qPCR applied on certain types of samples or because of aggregation-disaggregation of phage particles. Thus, (Hata et al., 2013) detected more PFUs than GC in the influent of a wastewater treatment plant, but detected more GC in the effluent. Additionally, the difference in GC and PFUs will likely increase after inactivation in water environments and after water treatment, since it is well know that phage GC signals are more persistent in nature and more resistant to treatments than the plaque assay measuring infectious viruses.

\subsection{Bacteriophages Infecting Bacteroides}

The method used for the Bacteroides phages, namely ISO-10705-4 (Anonymous, 2001), includes both the double agar layer (DAL) plaque assay method for the quantification of PFU and the presence/absence test. A simplified version of these methods can be read in Araujo et al. (2001). These methods are similar to those described for coliphages, the only difference being that Bacteroides has to be grown under anaerobic conditions and that incubation times are longer. However, anaerobic jars and sachets are appropriate for cultures in Petri dishes and screw caped tubes completely filled with culture medium are enough for liquid cultures. Manipulation can be done on the open bench. The ISO methods are applicable to all the host strains referred to earlier. Mooijman et al. (2005) proved that the implementation of the ISO standard method is feasible in routine microbiology laboratories without previous experience with phages.

The cost in material, media, reagents and labour for the detection of phages infecting Bacteroides is similar to that for detection of somatic coliphages with an additional 10-15 $\%$ for anaerobic conditions. It can be done in routine microbiology laboratories. Additionally, the ISO procedure includes optional steps for laboratories with limited equipment.

\subsection{Methods for Concentration}

The presence/absence method allows testing of relatively large volumes (up to one litre) (Grabow, 2001), however concentration may be required either because greater volumes need to be tested or because quantification is required. Most methods described for concentrating animal viruses are not adequate for concentrating phages (Grabow, 2001). For volumes ranging from 10 to $1000 \mathrm{~mL}$, two methods are recommended. For water with low turbidity, Sobsey et al. (1990) developed a simple, inexpensive and practical procedure for the recovery and detection of F-specific phages using mixed cellulose and acetate membrane filters with a diameter of $47 \mathrm{~mm}$ and a pore size of $0.45 \mu \mathrm{m}$ after addition of salts and $\mathrm{pH}$ adjustment. This method was slightly modified by Mendez et al. (2004b) showing an excellent performance for up to 1 litre of sample for concentrating somatic coliphages, Fspecific RNA phages and phages infecting Bacteroides. For samples with high turbidity, flocculation with magnesium hydroxide (Schulze and Lenk, 1983) is practicable for the 
three groups of phages(Contreras-Coll et al., 2002). Phage can also be concentrated by ultrafiltration as mentioned for other viruses.

\subsection{Data on Occurrence in the Environment}

\subsection{Faeces}

\subsubsection{Somatic coliphages}

Somatic coliphages have been isolated in variable percentages of human and animal stool samples (Table 4).

Table 4. Presence and concentrations of somatic coliphages in faeces

\begin{tabular}{|c|c|c|c|c|c|c|c|c|c|}
\hline Area & Host & $\begin{array}{c}\text { Number } \\
\text { of } \\
\text { species }^{\mathrm{a}}\end{array}$ & Method & $\begin{array}{l}\text { Extraction } \\
\text { procedure }\end{array}$ & $\begin{array}{c}\text { Amount } \\
\text { of } \\
\text { sample }^{b}\end{array}$ & $\begin{array}{l}\text { Detection } \\
\text { limit }\end{array}$ & $\begin{array}{c}\text { Percent } \\
\text { Positive } \\
\text { (Range) }^{\mathrm{c}} \\
\text { [numbers }_{\text {of }} \\
\text { samples] }^{\mathrm{d}} \\
\end{array}$ & $\begin{array}{c}\text { Concentration } \\
\text { Average } \\
\text { (range) }^{\mathbf{r}} \\
\text { PFU/g }\end{array}$ & Reference \\
\hline France & Human & 1 & ISO-DAL & $\begin{array}{l}\text { Suspension } \\
\text { in peptone } \\
\text { saline }\end{array}$ & $1 \mathrm{~g}$ & $1 / g$ & $\begin{array}{c}68 \% \\
{[193]}\end{array}$ & $\begin{array}{c}4.3 \mathrm{E}+01 \\
(<1 \text { to } \\
7.3 \mathrm{E}+05)\end{array}$ & $\begin{array}{c}\text { Gantzer et al., } \\
2002\end{array}$ \\
\hline Holland & Human & 1 & $\begin{array}{l}\text { ISO-like } \\
\text { DAL }\end{array}$ & $\begin{array}{l}\text { Suspension } \\
\text { in peptone } \\
\text { saline }\end{array}$ & $1 \mathrm{~g}$ & $10 / g$ & $\begin{array}{l}80 \% \\
{[10]}\end{array}$ & $6.1 \mathrm{E}+04$ & $\begin{array}{c}\text { Havelaar et al., } \\
1986\end{array}$ \\
\hline Holland & Animal & 7 & $\begin{array}{l}\text { ISO-like } \\
\text { DAL }\end{array}$ & $\begin{array}{l}\text { Suspension } \\
\text { in peptone } \\
\text { saline }\end{array}$ & $1 \mathrm{~g}$ & $10 / g$ & $\begin{array}{c}100 \% \\
(100 \text { to } \\
100) \\
{[70]}\end{array}$ & $\begin{array}{c}4.1 \mathrm{E}+04 \text { to } \\
2.2 \mathrm{E}+07\end{array}$ & $\begin{array}{c}\text { Havelaar et al., } \\
1986\end{array}$ \\
\hline Korea & Human & 1 & USEPA-SAL & $\begin{array}{l}\text { Suspension } \\
\text { in } \\
\text { phosphate } \\
\text { buffered } \\
\text { saline } \\
\text { (PBS) }\end{array}$ & $5 \mathrm{~g}$ & $1 / g$ & $\begin{array}{l}91 \% \\
{[11]}\end{array}$ & $\begin{array}{c}3.0 \mathrm{E}+02 \\
(<1 \text { to } \\
3.8 \mathrm{E}+04)\end{array}$ & Lee et al., 2009 \\
\hline Korea & Animal & 4 & USEPA-SAL & $\begin{array}{l}\text { Suspension } \\
\text { in PBS }\end{array}$ & $5 \mathrm{~g}$ & $1 / g$ & $\begin{array}{c}39.7 \% \\
(25 \text { to } 63) \\
{[29]}\end{array}$ & $\begin{array}{c}1.0 \mathrm{E}+01 \text { to } \\
1.4 \mathrm{E}+03 \\
(<1 \text { to } \\
1.0 \mathrm{E}+04)\end{array}$ & Lee et al., 2009 \\
\hline $\begin{array}{l}\text { South } \\
\text { Africa }\end{array}$ & Human & 1 & ISO- P/A & $\begin{array}{c}\text { Direct to } \\
\text { enrichment }\end{array}$ & $1 \mathrm{~g}$ & $1 / g$ & $\begin{array}{l}54 \% \\
{[90]}\end{array}$ & Not reported & $\begin{array}{c}\text { Grabow et al., } \\
1993\end{array}$ \\
\hline $\begin{array}{l}\text { South } \\
\text { Africa }\end{array}$ & Animal & 16 & ISO- P/A & $\begin{array}{c}\text { Direct to } \\
\text { enrichment }\end{array}$ & $1 \mathrm{~g}$ & $1 / g$ & $\begin{array}{c}38 \% \\
(38 \text { to100) } \\
{[155]}\end{array}$ & Not reported & $\begin{array}{c}\text { Grabow et al., } \\
1993\end{array}$ \\
\hline Spain & Human & 1 & ISO-DAL & $\begin{array}{l}\text { Suspension } \\
\text { in PBS }\end{array}$ & $1 \mathrm{~g}$ & $1 / g$ & $\begin{array}{c}49 \% \\
{[100]}\end{array}$ & $\begin{array}{c}1.0 \mathrm{E}+05 \\
(<1 \text { to } \\
1.7 \mathrm{E}+07)\end{array}$ & $\begin{array}{c}\text { Martinez-Castillo } \\
\text { et al., } 2013\end{array}$ \\
\hline Spain & $\begin{array}{l}\text { Animal } \\
\text { (Cattle) }\end{array}$ & 1 & ISO-DAL & $\begin{array}{l}\text { Suspension } \\
\text { in PBS }\end{array}$ & $1 \mathrm{~g}$ & $1 / g$ & $\begin{array}{c}100 \% \\
{[28]}\end{array}$ & $\begin{array}{c}8.7 \mathrm{E}+06 \\
(6.0 \mathrm{E}+04 \text { to } \\
3.1 \mathrm{E}+07)\end{array}$ & $\begin{array}{l}\text { Colomer-Lluch } \\
\text { et al., } 2011\end{array}$ \\
\hline Switzerland & Human & 1 & ISO-DAL & $\begin{array}{l}\text { Suspension } \\
\text { in peptone } \\
\text { saline }\end{array}$ & $50 \mathrm{~g}$ & $10 / g$ & $\begin{array}{l}73 \% \\
{[55]}\end{array}$ & $\begin{array}{c}2.5 \mathrm{E}+02 \\
(<10 \text { to } \\
6.8 \mathrm{E}+04)\end{array}$ & $\begin{array}{c}\text { Diston and } \\
\text { Wicki, } 2015\end{array}$ \\
\hline Switzerland & Animal & 7 & ISO-DAL & $\begin{array}{l}\text { Suspension } \\
\text { in peptone } \\
\text { saline }\end{array}$ & $50 \mathrm{gb} 1$ & $10 / g$ & $\begin{array}{c}82 \% \\
(82 \text { to } \\
100) \\
{[46]}\end{array}$ & $\begin{array}{c}1.0 \mathrm{E}+01 \text { to } \\
2.0 \mathrm{E}+07 \\
(<10 \text { to } \\
1.0 \mathrm{E}+08)\end{array}$ & $\begin{array}{c}\text { Diston and } \\
\text { Wicki, } 2015\end{array}$ \\
\hline USA & Animal & 12 & USEPA-SAL & $\begin{array}{l}\text { Suspension } \\
\text { in water }\end{array}$ & $1 \mathrm{~g}$ & $1 / g$ & $\begin{array}{l}\text { Isolation } \\
\text { in } 6 / 2 \\
\text { species } \\
{[260]}\end{array}$ & $<1$ to $6.0 \mathrm{E}+04$ & $\begin{array}{l}\text { McMinn et al., } \\
2014\end{array}$ \\
\hline
\end{tabular}

${ }^{a}$ Number of species tested; ${ }^{b}$ From a single stool, ${ }^{b 1}$ composite samples; ${ }^{c}$ Range of positive samples in the different species; ${ }^{\mathrm{d}}$ Sum of samples corresponding to the different species tested; ${ }^{\text {e }}$ Range of average values corresponding to the different species 
Reported percentages of positive human specimens range from 54 to $91 \%$, whereas those of animal samples range from $<1$ to $100 \%$. The variability is such that some publications report the isolation of somatic coliphages in all animal species tested and in $100 \%$ of the samples tested Havelaar et al., 1986) whereas other authors failed to isolate somatic coliphages from any sample of $50 \%$ of species analysed (McMinn et al., 2014). As well, the concentrations reported are very variable and range from $<1$ to $7.3 \times 10^{5} /$ gram in humans and from $<1$ to $10^{8}$ in animals. Animal species studied (Table 4) include farm, domestic and wild species more likely contributing to faecal contamination of the environment.

These percentages and concentrations are very likely an underestimation. Such supposition is grounded on the facts that stool is a very complex matrix and no methods have been settled for defining the amounts of sample to be analysed or the need of applying extraction procedures. Regarding the amount of sample to be tested, if, as expected, coliphages replicate as lytic phages in the gut following the kill the winner model of phage bacteria population dynamics (Rodriguez-Valera et al., 2009), the number of phages will probably vary in form of waves of abundance in the gut content moving towards the cecum. This model involves a phage-bacteria population dynamics in which an increase in a host population (the winner) is followed bv an increase in the rate at which that winner is killed by phages with the corresponding increase in the phage population. In fact, in measuring phages infecting Bacteroides, Tartera and Jofre (Tartera and Jofre, 1987) tested different stool specimens of the same individual and detected values ranging from $<1$ to $>2.4 \times 10^{8}$ infectious phages/gram; very likely composite samples will provide a better view of the presence and concentrations of phages in the stool samples. Additionally, Jones and Johns (Jones and Johns, 2009) reported for F-specific phages that increasing the amount of sample increased the percentage of samples from which phages were isolated as well as extraction and polyethylene glycol precipitation improved the detection.

\subsubsection{F-specific and F-specific RNA bacteriophages}

F-specific RNA phages have been isolated in variable percentages of human and animal stool samples (Table5). The same consideration as for somatic coliphages regarding the great variability of results reported apply for F-specific RNA phages. Reported percentages of positive human specimens range from 6 to $73 \%$, whereas those of animal samples of different species range from 0 to $100 \%$. Also, the concentrations reported are very variable and range from $<1$ to $1 \times 10^{4} \mathrm{PFU} /$ gram in humans and from $<1$ to $>1.2 \times 10^{6}$ in animals. Animal species studied (Table 5) include farm, domestic and wild species that most likely contribute to faecal contamination of the water environment.

Table 5. Presence and concentrations of F-specific and F-specific RNA phages in faeces

\begin{tabular}{|c|c|c|c|c|c|c|c|c|c|}
\hline Area & Host & $\begin{array}{c}\text { Number } \\
\text { of } \\
\text { species }^{\mathrm{a}}\end{array}$ & Method & $\begin{array}{l}\text { Extraction } \\
\text { procedure }\end{array}$ & $\begin{array}{l}\text { Amount } \\
\text { of } \\
\text { sample }^{b}\end{array}$ & $\begin{array}{c}\text { Detection } \\
\text { limit }\end{array}$ & $\begin{array}{c}\text { Percent } \\
\text { Positive } \\
\text { (Range) }^{\mathrm{c}} \\
\text { [number }_{\text {of }} \\
\text { samples] } \\
\end{array}$ & $\begin{array}{c}\text { Concentration } \\
\text { Average } \\
\text { (range) }^{\mathbf{e}} \\
\text { PFU/g }\end{array}$ & Reference \\
\hline Holland & Human & 1 & ISO-DAL & $\begin{array}{l}\text { Suspension } \\
\text { in peptone } \\
\text { saline }\end{array}$ & $1 \mathrm{~g}$ & $10 / g$ & $\begin{array}{l}10 \% \\
{[10]}\end{array}$ & $<1$ & $\begin{array}{c}\text { Havelaar } \\
\text { et al., } \\
1986\end{array}$ \\
\hline Holland & Animal & 7 & ISO-DAL & $\begin{array}{l}\text { Suspension } \\
\text { in peptone } \\
\text { saline }\end{array}$ & $1 \mathrm{~g}$ & $10 / g$ & $\begin{array}{c}0 \% \\
(0 \text { to } 100) \\
{[70]}\end{array}$ & $\begin{array}{c}<10 \text { to } \\
>1.2 \mathrm{E}+06 \mathrm{~d}\end{array}$ & $\begin{array}{c}\text { Havelaar } \\
\text { et al., } \\
1986\end{array}$ \\
\hline Korea & Human & 1 & USEPA-SAL & $\begin{array}{l}\text { Suspension } \\
\text { in PBS }\end{array}$ & $5 \mathrm{~g}$ & $1 / g$ & $\begin{array}{l}73 \% \\
{[11]}\end{array}$ & $\begin{array}{c}5 \\
(<1 \text { to } \\
2.8 \mathrm{E}+02)\end{array}$ & $\begin{array}{l}\text { Lee et al., } \\
\quad 2009\end{array}$ \\
\hline Korea & Animal & 4 & USEPA-SAL & $\begin{array}{l}\text { Suspension } \\
\text { in PBS }\end{array}$ & $5 \mathrm{~g}$ & $1 / g$ & $\begin{array}{l}25 \% \\
(25 \text { to } \\
100) \\
{[29]}\end{array}$ & $\begin{array}{c}1 \text { to } 5 \\
(<1 \text { to } \\
2.0 \mathrm{E}+02)\end{array}$ & $\begin{array}{l}\text { Lee et al., } \\
2009\end{array}$ \\
\hline $\begin{array}{l}\text { South } \\
\text { Africa }\end{array}$ & Human & 1 & ISO- P/A & $\begin{array}{c}\text { Direct to } \\
\text { enrichment }\end{array}$ & $1 \mathrm{~g}$ & $1 / g$ & $\begin{array}{l}26 \% \\
{[90]}\end{array}$ & - & $\begin{array}{c}\text { Grabow et } \\
\text { al., } 1993\end{array}$ \\
\hline $\begin{array}{l}\text { South } \\
\text { Africa }\end{array}$ & Animal & 16 & ISO- P/A & $\begin{array}{c}\text { Direct to } \\
\text { enrichment }\end{array}$ & $1 \mathrm{~g}$ & $1 / g$ & $\begin{array}{c}18.4 \% \\
(20 \text { to } 84) \\
{[155]}\end{array}$ & - & $\begin{array}{l}\text { Grabow et } \\
\text { al., } 1993\end{array}$ \\
\hline USA & Human & 1 & USEPA-SAL & $\begin{array}{l}\text { Suspension } \\
\text { in tryptone } \\
\text { broth }\end{array}$ & $1 \mathrm{~g}$ & $1 / g$ & $\begin{array}{c}8 \% \\
{[13]}\end{array}$ & $<1$ & $\begin{array}{l}\text { Calci et } \\
\text { al., } 1998\end{array}$ \\
\hline USA & Animal & 12 & USEPA-SAL & $\begin{array}{l}\text { Suspension } \\
\text { in tryptone } \\
\text { broth }\end{array}$ & $1 \mathrm{~g}$ & $1 / g$ & $\begin{array}{c}0 \% \\
(0 \text { to } 25) \\
{[1081]}\end{array}$ & 1.5 to $1.1 \mathrm{E}+04^{\mathrm{d}}$ & $\begin{array}{l}\text { Calci et } \\
\text { al., } 1998\end{array}$ \\
\hline
\end{tabular}

${ }^{a}$ Number of species tested; ${ }^{b}$ from a single stool sample; ${ }^{c}$ Range of positive samples in the different species; ${ }^{d}$ Sum of samples corresponding to the different species tested; ${ }^{e}$ Range of average values corresponding to the different species 
The comments regarding the potential underestimation of the values made for somatic coliphages are applicable to F-specific RNA phages.

Several reports on the distribution of subgroups in human and animal faeces are available. All reports indicate that subgroups II and III are generally associated with human faecal material, whereas subgroups I and IV make up the majority in animal faecal wastes. This distribution is observed whatever the method used. Nevertheless, this association is not always $100 \%$ exact. Thus, Havelaar et al. (1990) have detected subgroup II in pig faeces; Schaper et al (Schaper et al., 2002b) subgroup II in faeces of pigs, cattle and poultry; Hsu et al. (1995) subgroup II in pig faeces; Hartard et al. (2015) subgroup II in faeces of ducks and geese; and Cole and Sobsey (2003) subgroups II and III in faeces of cows.

\subsubsection{Bacteriophages infecting Bacteroides}

Phages infecting different strains of Bacteroides have been isolated in variable percentages of human and animal stool samples (Table 6). In this case, the host strain introduces the greater factor of variability since as indicated earlier Bacteroidesstrains differ in their capability to detect phages in different faecal sources. Bacteroides fragilis RYC2056, has been reported to recover phages from $28 \%$ of human stool specimens, although it also recovers phages from animal faeces (Puig et al., 1999), with the maximum incidence, $30 \%$, in pigs. Bacteroides fragilis HSP40 phages have been isolated from 10-13\% of human stool samples, but never from animal faeces, with values ranging from $>1$ to $1.2 \times 10^{4} \mathrm{PFU} /$ gram (Gantzer et al., 2002; Grabow et al., 1995; Tartera and Jofre, 1987). GB-124 has been reported in $4 \%$ of human samples and never in animal samples (Diston and Wicki, 2015; McMinn et al., 2014).

Table 6. Presence and concentrations of phages infecting different host strains of Bacteroides in faeces

\begin{tabular}{|c|c|c|c|c|c|c|c|c|c|}
\hline Area & Host & $\begin{array}{c}\text { Number } \\
\text { of } \\
\text { species }^{a}\end{array}$ & $\begin{array}{l}\text { Detection } \\
\text { Method }\end{array}$ & $\begin{array}{l}\text { Extraction } \\
\text { procedure }\end{array}$ & $\begin{array}{c}\text { Amount } \\
\text { of } \\
\text { sample }^{\mathrm{b}}\end{array}$ & $\begin{array}{l}\text { Detection } \\
\text { limit }\end{array}$ & $\begin{array}{c}\text { Percent } \\
\text { Positive } \\
\text { (Range) }^{\mathrm{d}} \\
\text { [number }^{\text {of }} \\
\text { samples] }^{\mathrm{c}} \\
\end{array}$ & $\begin{array}{c}\text { Concentration } \\
\text { Average } \\
\text { (range) }^{\mathrm{d}} \\
\text { PFU/g }\end{array}$ & Reference \\
\hline France & Human & 1 & $\begin{array}{l}\text { ISO PFU } \\
\text { (RYC2056) }\end{array}$ & $\begin{array}{l}\text { Suspension } \\
\text { in peptone } \\
\text { saline }\end{array}$ & $1 \mathrm{~g}$ & $1 / g$ & $\begin{array}{l}11.0 \% \\
{[193]}\end{array}$ & $\begin{array}{c}7.0 \mathrm{E}+01 \\
(<1 \text { to } 0.2 \mathrm{E}+04)\end{array}$ & $\begin{array}{l}\text { Gantzer et } \\
\text { al., } 2002\end{array}$ \\
\hline Spain & Animal & 5 & $\begin{array}{c}\text { ISO P/A } \\
\text { (RYC2056) }\end{array}$ & $\begin{array}{l}\text { Suspension } \\
\text { in peptone } \\
\text { saline }\end{array}$ & $1 g^{b 1}$ & $1 / g$ & $\begin{array}{c}0 \text { to } 31.0 \% \\
{[45]}\end{array}$ & - & $\begin{array}{c}\text { Puig et al., } \\
1999\end{array}$ \\
\hline Switzerland & Human & 1 & $\begin{array}{l}\text { ISO PFU } \\
\text { (GB124) }\end{array}$ & $\begin{array}{l}\text { Suspension } \\
\text { in peptone } \\
\text { saline }\end{array}$ & $50 \mathrm{~g}$ & $5 / g$ & $\begin{array}{l}4.0 \% \\
{[55]}\end{array}$ & $\begin{array}{c}5.5 \mathrm{E}+01 \\
(<5 \text { to } 1.0 \mathrm{E}+02)\end{array}$ & $\begin{array}{c}\text { Diston and } \\
\text { Wicki, } \\
2015\end{array}$ \\
\hline Switzerland & Animal & 7 & $\begin{array}{l}\text { ISO PFU } \\
\text { (GB124) }\end{array}$ & $\begin{array}{l}\text { Suspension } \\
\text { in peptone } \\
\text { saline }\end{array}$ & $50 \mathrm{~g}$ & $5 / g$ & $\begin{array}{l}0.0 \% \\
{[46]}\end{array}$ & $<5$ & $\begin{array}{l}\text { Diston and } \\
\text { Wicki, } \\
2015\end{array}$ \\
\hline USA & Animal & 12 & $\begin{array}{l}\text { ISO PFU } \\
\text { (GB124) }\end{array}$ & Water & $1 \mathrm{~g}$ & $1 / g$ & $\begin{array}{l}0.0 \% \\
{[260]}\end{array}$ & $<1$ & $\begin{array}{l}\text { McMinn et } \\
\text { al., } 2014\end{array}$ \\
\hline
\end{tabular}

${ }^{\mathrm{a}}$ Number of species tested; ${ }^{\mathrm{b}}$ Single stool, ${ }^{\mathrm{b} 1}$ Composite sample; ${ }^{\mathrm{c}}$ Sum of samples corresponding to the different species tested; ${ }^{d}$ Range of positive samples in the different species

\subsection{Raw Wastewater}

\subsubsection{Somatic coliphages}

Somatic coliphages are the most abundant indicator phages in raw municipal and hospital wastewater. Their concentrations are usually less than one order of magnitude lower than those of faecal coliforms (or E. coli) wherever they have been counted (Table 7). Bacterial indicators and somatic coliphage concentrations in raw municipal wastewaters are comparable regardless of the geographical location and the income level of the country. 
Table 7. Concentrations of somatic coliphages in untreated sewage from municipal wastewater (human faecal source)

\begin{tabular}{|c|c|c|c|c|c|c|c|}
\hline Area & $\begin{array}{c}\text { Host } \\
\text { strain }\end{array}$ & $\begin{array}{c}\text { Sample } \\
\text { type/ } \\
\text { Matrices }\end{array}$ & $\begin{array}{l}\text { Detection } \\
\text { Method }\end{array}$ & $\begin{array}{c}\text { Number } \\
\text { of } \\
\text { samples }\end{array}$ & $\begin{array}{l}\text { Percent } \\
\text { Positive }\end{array}$ & $\begin{array}{c}\text { Concentration } \\
\text { Average } \\
\text { (range) PFU/100 mL }\end{array}$ & Reference \\
\hline Argentina & $\begin{array}{c}\text { E coli } \\
\text { WG5 }\end{array}$ & $\begin{array}{c}\text { Raw } \\
\text { sewage }\end{array}$ & $\begin{array}{c}\text { ISO } \\
10705-2\end{array}$ & 36 & $100 \%$ & $\begin{array}{c}6.0 \mathrm{E}+05 \\
(1.0 \mathrm{E}+05 \text { to } \\
5.0 \mathrm{E}+06)\end{array}$ & $\begin{array}{l}\text { Lucena et al., } \\
\qquad 2004\end{array}$ \\
\hline Canada & $\begin{array}{l}\text { E. coli } \\
\text { C }\end{array}$ & $\begin{array}{c}\text { Raw } \\
\text { sewage }\end{array}$ & $\begin{array}{l}\text { APHA } \\
\text { previous } \\
\text { 22nd } \\
\text { edition }\end{array}$ & 10 & $100 \%$ & $\begin{array}{c}2.9 \mathrm{E}+05 \\
(1.0 \mathrm{E}+05 \text { to } \\
7.0 \mathrm{E}+05)\end{array}$ & $\begin{array}{c}\text { Zhang and } \\
\text { Farahbakhsh, } \\
2007\end{array}$ \\
\hline China & $\begin{array}{l}\text { E. coli } \\
\text { WG5 }\end{array}$ & $\begin{array}{c}\text { Raw } \\
\text { sewage }\end{array}$ & $\begin{array}{c}\text { ISO } \\
10705-2\end{array}$ & 18 & $100 \%$ & $\begin{array}{c}2.0 \mathrm{E}+06 \\
(1.0 \mathrm{E}+05 \text { to } 4.9 \\
\mathrm{E}+06)\end{array}$ & Fu et al., 2010 \\
\hline Colombia & $\begin{array}{l}\text { E. coli } \\
\text { WG5 }\end{array}$ & $\begin{array}{c}\text { Raw } \\
\text { sewage }\end{array}$ & $\begin{array}{c}\text { ISO } \\
10705-2\end{array}$ & 36 & $100 \%$ & $\begin{array}{c}6.0 \mathrm{E}+05 \\
(1.3 \mathrm{E}+03 \text { to } \\
1.0 \mathrm{E}+07)\end{array}$ & $\begin{array}{l}\text { Lucena et al., } \\
\qquad 2004\end{array}$ \\
\hline $\begin{array}{l}\text { European } \\
\text { Countries } \\
\text { (Spain, } \\
\text { Holland, } \\
\text { France, UK, } \\
\text { Germany, } \\
\text { Greece, } \\
\text { Italy, } \\
\text { Finland, } \\
\text { Austria } \\
\text { Ireland) }\end{array}$ & $\begin{array}{l}\text { E. coli } \\
\text { WG5 }\end{array}$ & $\begin{array}{c}\text { Raw } \\
\text { sewage }\end{array}$ & $\begin{array}{c}\text { ISO } \\
10705-2\end{array}$ & 29 & $100 \%$ & $\begin{array}{c}\text { Median } 8.5 \mathrm{E}+06 \\
(4.0 \mathrm{E}+04 \text { to } 3.0 \mathrm{E} \\
+07)\end{array}$ & $\begin{array}{c}\text { Contreras-Coll et } \\
\text { al., } 2002\end{array}$ \\
\hline $\begin{array}{l}\text { European } \\
\text { Countries } \\
\text { (France, } \\
\text { Spain, } \\
\text { Sweden, } \\
\text { UK) }\end{array}$ & $\begin{array}{l}\text { E. coli } \\
\text { WG5 }\end{array}$ & $\begin{array}{c}\text { Municipal } \\
\text { sewage } \\
\text { and } \\
\text { hospital } \\
\text { wastewater }\end{array}$ & $\begin{array}{c}\text { ISO } \\
10705-2\end{array}$ & 110 & $100 \%$ & $\begin{array}{c}1.0 \mathrm{E}+06 \\
(1.0 \mathrm{E}+04 \text { to } \\
4.5 \mathrm{E}+07)\end{array}$ & $\begin{array}{c}\text { Blanch et al., } \\
2006\end{array}$ \\
\hline Netherlands & $\begin{array}{l}\text { E. coli } \\
\text { WG5 }\end{array}$ & $\begin{array}{c}\text { Raw } \\
\text { sewage }\end{array}$ & $\begin{array}{c}\text { ISO } \\
10705-2\end{array}$ & 5 & $100 \%$ & $\begin{array}{c}5.0 \mathrm{E}+05 \\
(2.9 \mathrm{E}+05 \text { to } \\
7.3 \mathrm{E}+05)\end{array}$ & $\begin{array}{l}\text { Lodder and de } \\
\text { Roda } \\
\text { Husman, } 2005\end{array}$ \\
\hline $\begin{array}{l}\text { South } \\
\text { Africa }\end{array}$ & $\begin{array}{l}\text { E. coli } \\
\text { WG5 }\end{array}$ & $\begin{array}{c}\text { Settled } \\
\text { municipal } \\
\text { wastewater }\end{array}$ & $\begin{array}{c}\text { ISO } \\
10705-2\end{array}$ & 24 & $100 \%$ & $\begin{array}{c}1.6 \mathrm{E}+06 \\
(4.0 \mathrm{E}+05 \text { to } \\
7.1 \mathrm{E}+06)\end{array}$ & $\begin{array}{c}\text { Grabow et al., } \\
1993\end{array}$ \\
\hline Tunisia & $\begin{array}{l}\text { E. coli } \\
\text { WG5 }\end{array}$ & $\begin{array}{c}\text { Raw } \\
\text { sewage }\end{array}$ & $\begin{array}{c}\text { ISO } \\
10705-2\end{array}$ & 15 & $100 \%$ & $\begin{array}{l}\text { Median } 1.0 \mathrm{E}+06 \\
(1.0 \mathrm{E}+05 \text { to } 1.5 \mathrm{E} \\
+07)\end{array}$ & $\begin{array}{c}\text { Yahya et al., } \\
2015\end{array}$ \\
\hline
\end{tabular}

In Argentina, Lucena et al. (2003) studied samples of twenty-eight septic tanks and reported the detection of somatic coliphages in all samples tested with values ranging from $10^{6}$ to $10^{7} \mathrm{PFU} / 100 \mathrm{~mL}$, which are similar to those reported for sewage in the area.
The reported values of somatic coliphages range from $10^{4}-10^{5} \mathrm{PFU} / 100 \mathrm{~mL}$ in manures to $4 \times 10^{8}$ in abattoir wastewaters (Table 8). The proportion of these counts with counts of faecal coliforms and/or E. coli are similar to those found in municipal wastewater. 
Table 8. Concentrations of somatic coliphages in untreated point sources of animal pollution

\begin{tabular}{|c|c|c|c|c|c|c|c|c|}
\hline Area & $\begin{array}{l}\text { Host } \\
\text { strain }\end{array}$ & $\begin{array}{l}\text { Sample type/ } \\
\text { Matrices }\end{array}$ & $\begin{array}{l}\text { Detection } \\
\text { Method }\end{array}$ & $\begin{array}{l}\text { Faecal } \\
\text { Source }\end{array}$ & $\begin{array}{l}\text { Number of } \\
\text { samples }\end{array}$ & $\begin{array}{l}\text { Percent } \\
\text { Positive }\end{array}$ & $\begin{array}{c}\text { Concentration } \\
\text { Average } \\
\text { (range) PFU/100 } \\
\text { mL }\end{array}$ & Reference \\
\hline $\begin{array}{l}\text { Colombia } \\
\text { (South } \\
\text { America) }\end{array}$ & $\begin{array}{l}\text { E. coli } \\
\text { WG5 }\end{array}$ & $\begin{array}{c}\text { Slaughterhouse } \\
\text { wastewater } \\
\text { effluents }\end{array}$ & ISO $10705-2$ & Animal & 5 & $100 \%$ & $\begin{array}{c}(4.0 \mathrm{E}+06 \text { to } \\
5.0 \mathrm{E}+07)\end{array}$ & $\begin{array}{l}\text { Venegas et } \\
\text { al., } 2015\end{array}$ \\
\hline $\begin{array}{l}\text { Europe } \\
\text { (France, } \\
\text { UK, } \\
\text { Spain, } \\
\text { Sweden } \\
\text { and } \\
\text { Cyprus) }\end{array}$ & $\begin{array}{l}\text { E. coli } \\
\text { WG5 }\end{array}$ & $\begin{array}{l}\text { Slaughterhouse } \\
\text { wastewater } \\
\text { effluents and } \\
\text { slurries }\end{array}$ & ISO $10705-2$ & $\begin{array}{l}\text { Animal } \\
\text { :Pigs, } \\
\text { cows and } \\
\text { poultry }\end{array}$ & $\begin{array}{c}57 \\
\text { wastewater } \\
+59 \\
\text { slurries }\end{array}$ & $100 \%$ & $\begin{array}{c}5.0 \mathrm{E}+06 \\
(1.2 \mathrm{E}+02 \text { to } \\
4.0 \mathrm{E}+09)\end{array}$ & $\begin{array}{l}\text { Blanch et } \\
\text { al., } 2006\end{array}$ \\
\hline Holland & $\begin{array}{l}\text { E. coli } \\
\text { WG5 }\end{array}$ & $\begin{array}{c}\text { Slaughterhouse } \\
\text { wastewater } \\
\text { effluents }\end{array}$ & ISO $10705-2$ & $\begin{array}{l}\text { Animal: } \\
\text { Pigs and } \\
\text { calves }\end{array}$ & 19 & $100 \%$ & $4.5 \mathrm{E}+06$ & $\begin{array}{l}\text { Havelaar } \\
\text { et al., } \\
1986\end{array}$ \\
\hline $\begin{array}{l}\text { New } \\
\text { Zealand }\end{array}$ & $\begin{array}{l}\text { E. coli } \\
\text { NZRM } \\
2718\end{array}$ & $\begin{array}{l}\text { Meat processing } \\
\text { lagoon }\end{array}$ & $\begin{array}{c}\text { APHA } \\
\text { previous } \\
\text { 22nd edition }\end{array}$ & Animal & 25 & $100 \%$ & $\begin{array}{c}8.8 E+03 \\
(8.0 E+02 \text { to } \\
6.3 E+04)\end{array}$ & $\begin{array}{l}\text { Donnison } \\
\text { and Ross, } \\
1995\end{array}$ \\
\hline $\begin{array}{l}\text { South } \\
\text { Africa }\end{array}$ & $\begin{array}{l}\text { E. coli } \\
\text { WG5 }\end{array}$ & $\begin{array}{l}\text { Slaughterhouse } \\
\text { process water }\end{array}$ & ISO $10705-2$ & Animal & 12 & $100 \%$ & $\begin{array}{c}2.8 E+06 \\
(2.5 E+04 \text { to } \\
3.3 E+04)\end{array}$ & $\begin{array}{l}\text { Grabow et } \\
\text { al., } 1993\end{array}$ \\
\hline $\begin{array}{l}\text { Tunisia } \\
\text { (North } \\
\text { Africa) }\end{array}$ & $\begin{array}{l}\text { E. coli } \\
\text { WG5 }\end{array}$ & $\begin{array}{c}\text { Slaughterhouse } \\
\text { wastewater } \\
\text { effluents }\end{array}$ & ISO $10705-2$ & Animal & 6 & $100 \%$ & $\begin{array}{c}2.0 \mathrm{E}+06 \\
(1.0 \mathrm{E}+04 \text { to } \\
1.7 \mathrm{E}+07)\end{array}$ & $\begin{array}{l}\text { Yahya et } \\
\text { al., } 2015\end{array}$ \\
\hline USA & $\begin{array}{l}\text { E. coli } \\
\text { CN13 }\end{array}$ & $\begin{array}{c}\text { Swine wastewater } \\
\text { lagoon }\end{array}$ & USEPA 1602 & $\begin{array}{l}\text { Animal } \\
\text { Swine }\end{array}$ & 10 & $100 \%$ & $2.5 E+07$ & $\begin{array}{l}\text { Hill and } \\
\text { Sobsey, } \\
1998\end{array}$ \\
\hline
\end{tabular}

Importantly enough, at source of pollution, somatic coliphages do not show seasonal differences (Muniesa et al., 2012; Zhang and Farahbakhsh, 2007).

\subsubsection{F-specific and F-specific RNA bacteriophages}

F-specific phages and F-specific RNA phages are the second most abundant indicator phages in raw municipal and hospital wastewater with most frequently reported values ranging from $10^{4}$ to $10^{6} \mathrm{PFU} / 100 \mathrm{~mL}$. These values are usually between one and two orders of magnitude lower than the numbers of faecal coliforms (or E. coli) and somatic coliphages (Table 9). The numbers of F-specific and F-specific RNA phages in wastewaters are comparable wherever they have been determined regardless of the geographical location and the income (level of development) of the country (region/area). Numbers of Fspecific phages in sewage do not show seasonal differences (Haramoto et al., 2015; Zhang and Farahbakhsh, 2007).

Table 9. Concentrations of F-specific and F-specific RNA phages in raw municipal sewage (Faecal Source Human)

\begin{tabular}{|c|c|c|c|c|c|c|}
\hline Area & Host strains & Detection Method & $\begin{array}{c}\text { Number of } \\
\text { samples }\end{array}$ & $\begin{array}{l}\text { Percent } \\
\text { Positive }\end{array}$ & $\begin{array}{c}\text { Concentration }^{\mathrm{a}, \mathrm{b}} \\
\text { Average (range) } \\
\text { PFU/100 mL }\end{array}$ & Reference \\
\hline Argentina & $\begin{array}{c}S . \\
\text { typhimurium } \\
\text { WG49 }\end{array}$ & ISO 10705-1 & 36 & $100 \%$ & $\begin{array}{c}7.0 \mathrm{E}+04^{\mathrm{b}} \\
(1.5 \mathrm{E}+03 \text { to } \\
1.2 \mathrm{E}+06)\end{array}$ & $\begin{array}{c}\text { Lucena et al., } \\
2003\end{array}$ \\
\hline Canada & $\begin{array}{c}\text { E. coli } \\
\text { HS(pFamp) }\end{array}$ & Double agar layer method & 10 & $100 \%$ & $\begin{array}{c}1.8 \mathrm{E}+05^{\mathrm{a}} \\
(5.0 \mathrm{E}+04 \text { to } \\
5.0 \mathrm{E}+05)\end{array}$ & $\begin{array}{c}\text { Zhang and } \\
\text { Farahbakhsh, } \\
2007\end{array}$ \\
\hline Colombia & $\begin{array}{c}S . \\
\text { typhimurium } \\
\text { WG49 }\end{array}$ & ISO $10705-1$ & 38 & $100 \%$ & $\begin{array}{c}2.0 \mathrm{E}+05^{\mathrm{b}} \\
(1.0 \mathrm{E}+04 \text { to } \\
2.0 \mathrm{E}+06)\end{array}$ & $\begin{array}{c}\text { Lucena et al., } \\
2003\end{array}$ \\
\hline
\end{tabular}




\begin{tabular}{|c|c|c|c|c|c|c|}
\hline Area & Host strains & Detection Method & $\begin{array}{c}\text { Number of } \\
\text { samples }\end{array}$ & $\begin{array}{l}\text { Percent } \\
\text { Positive }\end{array}$ & $\begin{array}{c}\text { Concentration }^{\mathrm{a}, \mathrm{b}} \\
\text { Average (range) } \\
\text { PFU/100 mL } \\
\end{array}$ & Reference \\
\hline $\begin{array}{l}\text { European } \\
\text { Countries } \\
\text { (Spain, } \\
\text { Holland, } \\
\text { France, UK, } \\
\text { Germany, } \\
\text { Greece, } \\
\text { Italy, } \\
\text { Finland, } \\
\text { Austria, } \\
\text { Ireland) }\end{array}$ & $\begin{array}{c}\text { S. } \\
\text { typhimurium } \\
\text { WG49 } \\
\end{array}$ & ISO 10705-1 & 29 & $100 \%$ & $\begin{array}{c}6.5 \mathrm{E}+05^{\mathrm{b}} \\
(1.0 \mathrm{E}+04 \text { to } \\
1.0 \mathrm{E}+06)\end{array}$ & $\begin{array}{l}\text { Contreras-Coll } \\
\text { et al., } 2002\end{array}$ \\
\hline $\begin{array}{l}\text { European } \\
\text { Countries } \\
\text { (France, } \\
\text { Spain, } \\
\text { Sweden, } \\
\text { UK) }\end{array}$ & $\begin{array}{c}\text { S. } \\
\text { typhimurium } \\
\text { WG49 }\end{array}$ & ISO 10705-1 & 110 & $100 \%$ & $\begin{array}{c}2.0 \mathrm{E}+05^{\mathrm{b}, \mathrm{d}} \\
(5.0 \mathrm{E}+01 \text { to } \\
9.0 \mathrm{E}+06)\end{array}$ & $\begin{array}{c}\text { Blanch et al., } \\
2006\end{array}$ \\
\hline Japan & $\begin{array}{c}S . \\
\text { typhimurium } \\
\text { WG49 }\end{array}$ & ISO 10705-1 & 24 & $100 \%$ & $6.0 \mathrm{E}+05^{\mathrm{a}}$ & $\begin{array}{c}\text { Hata et al., } \\
2013\end{array}$ \\
\hline Netherlands & $\begin{array}{c}S . \\
\text { typhimurium } \\
\text { WG49 }\end{array}$ & ISO 10705-1 & 5 & $100 \%$ & $\begin{array}{c}3.2 \mathrm{E}+05^{\mathrm{a}} \\
(6.7 \mathrm{E}+04 \text { to } \\
8.4 \mathrm{E}+06)\end{array}$ & $\begin{array}{c}\text { Lodder and de } \\
\text { Roda } \\
\text { Husman, } 2005\end{array}$ \\
\hline $\begin{array}{l}\text { South } \\
\text { Africa }\end{array}$ & $\begin{array}{c}\text { S. } \\
\text { typhimurium } \\
\text { WG49 }\end{array}$ & ISO 10705-1 & 24 & $100 \%$ & $\begin{array}{c}3.8 \mathrm{E}+05^{\mathrm{a}, \mathrm{c}} \\
(7.0 \mathrm{E}+04 \text { to } \\
1.2 \mathrm{E}+06)\end{array}$ & $\begin{array}{c}\text { Grabow et al., } \\
1993\end{array}$ \\
\hline Tunisia & $\begin{array}{c}\text { S. } \\
\text { typhimurium } \\
\text { WG49 }\end{array}$ & ISO 10705-1 & 15 & $100 \%$ & $\begin{array}{c}1.0 \mathrm{E}+05^{\mathrm{b}} \\
(1.0 \mathrm{E}+03 \text { to } \\
1.7 \mathrm{E}+06)\end{array}$ & $\begin{array}{c}\text { Yahya et al., } \\
2015\end{array}$ \\
\hline USA & $\begin{array}{c}\text { E. coli } \\
\text { HS(pFamp) }\end{array}$ & USEPA1602 & 14 & $100 \%$ & $\begin{array}{c}5.2 \mathrm{E}+05^{\mathrm{a}} \\
(8.5 \mathrm{E}+04 \text { to } \\
8.7 \mathrm{E}+05)\end{array}$ & $\begin{array}{c}\text { Calci et al., } \\
1998\end{array}$ \\
\hline
\end{tabular}

${ }^{\mathrm{a}}$ F-specific phages; ${ }^{\mathrm{b}} \mathrm{F}$-specific RNA phages ${ }^{\mathrm{c}}$ raw sewage after settling; ${ }^{\mathrm{d}}$ included hospital wastewater

Lucena et al. (2003) enumerated F-specific RNA phages by the ISO methods of twenty-eight septic tank samples in Argentina and reported the detection of F-specific RNA phages in all samples tested with values ranging from $10^{5}$ to $10^{6} \mathrm{PFU} / 100 \mathrm{~mL}$, which are similar to those reported for sewage in the area. Calci et al. (1998) using the USEPA methods detected F-specific phages in 10 of 17 samples of septic tank samples with values ranging from $<10$ to 10 PFU/100 mL.

Also, F-specific and F-specific RNA phages are detected in substantial concentrations in abattoir wastewater and animal slurries and manures. The reported values range from $10^{4} \mathrm{PFU} / 100 \mathrm{~mL}$ in animal waste slurries to $2 \times 10^{8}$ in abattoir wastewaters (Table 10). 
Table 10. Concentrations of F-specific and F-specific RNA phages in point sources of animal faecal pollution

\begin{tabular}{|c|c|c|c|c|c|c|c|}
\hline Area & Host strain & $\begin{array}{l}\text { Sample type/ } \\
\text { Matrices }\end{array}$ & $\begin{array}{l}\text { Detection } \\
\text { Method }\end{array}$ & $\begin{array}{l}\text { Number } \\
\text { of } \\
\text { samples }\end{array}$ & $\begin{array}{l}\text { Percent } \\
\text { Positive }\end{array}$ & $\begin{array}{c}\text { Concentration }^{\mathrm{a}, \mathrm{b}} \\
\text { Average (range) } \\
\text { PFU/ } 100 \text { mL }\end{array}$ & Reference \\
\hline $\begin{array}{l}\text { European } \\
\text { Countries } \\
\text { (Spain, } \\
\text { Holland, } \\
\text { France, } \\
\text { UK, } \\
\text { Germany, } \\
\text { Greece, } \\
\text { Italy, } \\
\text { Finland, } \\
\text { Austria, } \\
\text { Ireland) }\end{array}$ & $\begin{array}{c}\text { S. } \\
\text { typhimurium } \\
\text { WG49 }\end{array}$ & $\begin{array}{l}\text { Slaughterhouse } \\
\text { wastewater effluents } \\
\text { and slurries }\end{array}$ & ISO 10705-1 & 100 & $100 \%$ & $\begin{array}{c}6.0 \mathrm{E}+04 \mathrm{~b} \\
(5.0 \mathrm{E}+01 \text { to } 2.6 \mathrm{E}+08)\end{array}$ & $\begin{array}{l}\text { Blanch et } \\
\text { al., } 2006\end{array}$ \\
\hline Holland & $\begin{array}{c}S . \\
\text { typhimurium } \\
\text { WG49 }\end{array}$ & $\begin{array}{l}\text { Slaughterhouse } \\
\text { wastewater }\end{array}$ & ISO $10705-1$ & 19 & $100 \%$ & $3.5 \mathrm{E}+06^{\mathrm{a}, \mathrm{c}}$ & $\begin{array}{l}\text { Havelaar } \\
\text { et al., } \\
1990\end{array}$ \\
\hline $\begin{array}{l}\text { New } \\
\text { Zealand }\end{array}$ & $\begin{array}{c}S . \\
\text { typhimurium } \\
\text { WG49 }\end{array}$ & $\begin{array}{l}\text { Meat processing } \\
\text { Lagoon }\end{array}$ & ISO 10705-1 & 14 & $100 \%$ & $\begin{array}{c}4.8 \mathrm{E}+03^{\mathrm{b}} \\
(1.0 \mathrm{E}+03 \text { to } 5.1 \mathrm{E}+04)\end{array}$ & $\begin{array}{l}\text { Donnison } \\
\text { and Ross, } \\
1995\end{array}$ \\
\hline $\begin{array}{l}\text { South } \\
\text { Africa }\end{array}$ & $\begin{array}{c}\text { S. } \\
\text { typhimurium } \\
\text { WG49 }\end{array}$ & $\begin{array}{l}\text { Slaughterhouse } \\
\text { wastewater }\end{array}$ & ISO 10705-1 & 24 & $100 \%$ & $\begin{array}{c}1.6 \mathrm{E}+05^{\mathrm{a}} \\
(1.5 \mathrm{E}+03 \text { to } 4.9 \mathrm{E}+05)\end{array}$ & $\begin{array}{l}\text { Grabow et } \\
\text { al., } 1993\end{array}$ \\
\hline USA & $\begin{array}{l}\text { E. coli HS } \\
\text { (pFamp) }\end{array}$ & Raw swine wastewater & USEPA 1602 & 10 & $100 \%$ & $6.4 \mathrm{E}+04^{\mathrm{a}}$ & $\begin{array}{l}\text { Hill and } \\
\text { Sobsey, } \\
1998\end{array}$ \\
\hline
\end{tabular}

The subgroup percentages detected in raw wastewaters are reported in Table 11. As in the case of faeces, this distribution is not absolute. Most of the data reported in table 11 refer to phages enumerated by either the USEPA or the ISO methods and subgrouping of the phages in plaques. Wolf et al. (2010) and Hata et al. (2013) detected GC by multiplex RT-q-PCR and RT-q-PCR. 
Table 11. F-specific RNA bacteriophages subgroups distribution in different point sources of faecal contamination

\begin{tabular}{|c|c|c|c|c|c|c|c|c|}
\hline \multirow[b]{2}{*}{ Area } & \multirow[b]{2}{*}{$\begin{array}{l}\text { Sample } \\
\text { type }\end{array}$} & \multirow{2}{*}{ Method } & \multirow{2}{*}{$\begin{array}{c}\text { F-specific } \\
\text { RNA } \\
\text { phages } \\
\text { (PFU/100 } \\
\text { mL) } \\
\end{array}$} & \multicolumn{4}{|c|}{$\%$ Subgroups $^{\mathrm{a}}$} & \multirow{2}{*}{ Reference } \\
\hline & & & & I & II & III & IV & \\
\hline Holland & $\begin{array}{c}\text { Hospital } \\
\text { raw } \\
\text { wastewater }\end{array}$ & $\begin{array}{l}\text { Plaques + } \\
\text { serology }\end{array}$ & $\begin{array}{c}1.0 \mathrm{E}+06 \\
\text { to1.0 E +07 }\end{array}$ & $1 \mathrm{~V}$ & 42 & $\mathrm{U}$ & $\mathrm{PM}$ & $\begin{array}{l}\text { Havelaar } \\
\text { et al., } 1990\end{array}$ \\
\hline Holland & $\begin{array}{l}\text { Wastewater } \\
\text { raw abattoir }\end{array}$ & $\begin{array}{l}\text { Plaques + } \\
\text { serology }\end{array}$ & $1.0 \mathrm{E}+05$ & 77 & 0 & 6 & 16 & $\begin{array}{l}\text { Havelaar } \\
\text { et al.,1990 }\end{array}$ \\
\hline Japan & $\begin{array}{c}\text { Municipal } \\
\text { raw wastewater }\end{array}$ & $\begin{array}{l}\text { Plaques + } \\
\text { qRT-PCR }\end{array}$ & $\sim 1.6 \mathrm{E}+05$ & 1 & 41 & 20 & 3 & $\begin{array}{l}\text { Haramoto } \\
\text { et al., } 2015\end{array}$ \\
\hline Japan & $\begin{array}{l}\text { Secondary } \\
\text { effluent } \\
\text { (municipal) }\end{array}$ & $\begin{array}{l}\text { Plaques + } \\
\text { qRT-PCR }\end{array}$ & $\sim 3.0 \mathrm{E}+02$ & 73 & 13 & 8 & 0 & $\begin{array}{l}\text { Haramoto } \\
\text { et al., } 2015\end{array}$ \\
\hline Japan & $\begin{array}{c}\text { Municipal } \\
\text { raw } \\
\text { wastewater }\end{array}$ & $\begin{array}{l}\text { RT-qPCR } \\
\text { (GC) }\end{array}$ & $\sim 4.0 \mathrm{E}+05$ & 10 & 50 & 40 & - & $\begin{array}{l}\text { Hata et } \\
\text { al., } 2013\end{array}$ \\
\hline Japan & $\begin{array}{l}\text { Secondary } \\
\text { effluent } \\
\text { (municipal) }\end{array}$ & $\begin{array}{l}\text { RT-qPCR } \\
\text { (GC) }\end{array}$ & $\sim 1.0 \mathrm{E}+04$ & $>70$ & - & $<10$ & - & $\begin{array}{l}\text { Hata et } \\
\text { al., } 2013\end{array}$ \\
\hline $\begin{array}{l}\text { South } \\
\text { Africa }\end{array}$ & $\begin{array}{c}\text { Hospital } \\
\text { raw } \\
\text { wastewater }\end{array}$ & $\begin{array}{c}\text { Plaques + } \\
\text { plaque } \\
\text { hybridization }\end{array}$ & $1.0 \mathrm{E}+05$ & 6 & 42 & 52 & 0 & $\begin{array}{l}\text { Schaper } \\
\text { and Jofre, } \\
2000\end{array}$ \\
\hline Spain & $\begin{array}{c}\text { Municipal } \\
\text { raw } \\
\text { wastewater }\end{array}$ & $\begin{array}{c}\text { Plaques + } \\
\text { plaque } \\
\text { hybridization }\end{array}$ & $\begin{array}{c}1.0 \mathrm{E}+05 \\
\text { to } \\
1.0 \mathrm{E}+06\end{array}$ & 2.2 & 61.5 & 34.7 & 1.6 & $\begin{array}{l}\text { Schaper } \\
\text { and Jofre, } \\
2000\end{array}$ \\
\hline Spain & $\begin{array}{l}\text { Secondary } \\
\text { effluent } \\
\text { (municipal) }\end{array}$ & $\begin{array}{c}\text { Plaques + } \\
\text { plaque } \\
\text { hybridization }\end{array}$ & $1.0 \mathrm{E}+04$ & 54.3 & 43.3 & 1.7 & 0.7 & $\begin{array}{l}\text { Schaper } \\
\text { and Jofre, } \\
2000\end{array}$ \\
\hline USA & $\begin{array}{c}\text { Municipal } \\
\text { raw } \\
\text { wastewater }\end{array}$ & $\begin{array}{l}\text { Replication } \\
\text { of phages in } \\
\text { host strain } \\
\text { followed by } \\
\text { agglutination } \\
\text { with specific } \\
\text { antibodies } \\
\text { (CLAT) }\end{array}$ & $\sim 5.0 \mathrm{E}+04$ & 23 & 10 & 57 & 0 & $\begin{array}{l}\text { Brion et } \\
\text { al., } 2002\end{array}$ \\
\hline USA & $\begin{array}{c}\text { Municipal raw } \\
\text { wastewater }\end{array}$ & CLAT & $\sim 3.0 \mathrm{E}+05$ & 3.8 & 53.8 & 12.9 & 3.8 & $\begin{array}{l}\text { Cole et } \\
\text { al., } 2003\end{array}$ \\
\hline
\end{tabular}

${ }^{a}$ Values indicate the percentage of samples where the subgroup was detected. If the percentages do not sum 100 , it means that there were untyped plaques.

\subsubsection{Bacteriophages infecting Bacteroides}

In this case, the numbers detected depend on the host strains used since these differ in detection regarding the source of faecal contamination and there are also some geographical differences.
Concentration of phages detected by the non-discerning strain RYC2056 are relatively consistent everywhere around the world both in human and animal wastewaters with most frequent values ranging from $10^{4}$ to $10^{5}$ PFUs/100 mL. (Table 12). 
Table 12. Concentrations of phages in raw sewage detected by Bacteroides fragilis strain RYC2056

\begin{tabular}{|c|c|c|c|c|c|c|}
\hline Area & Sample type/ Matrices & $\begin{array}{l}\text { Faecal Source / } \\
\text { Host indicated }\end{array}$ & $\begin{array}{l}\text { Number of } \\
\text { samples }\end{array}$ & $\begin{array}{l}\text { Percent } \\
\text { positive }\end{array}$ & $\begin{array}{c}\text { Concentration }^{\mathrm{a}} \\
\text { Average } \\
\text { (range) PFU/100 } \mathbf{~ m L} \\
\end{array}$ & Reference \\
\hline $\begin{array}{l}\text { Argentina, } \\
\text { Colombia, } \\
\text { France } \\
\text { and } \\
\text { Spain. }\end{array}$ & Municipal sewage & Human & 104 & $100 \%$ & $6.0 \mathrm{E}+04$ & $\begin{array}{l}\text { Lucena et } \\
\text { al., } 2003\end{array}$ \\
\hline Colombia & Municipal sewage & Human & 5 & $100 \%$ & $1.2 \mathrm{E}+04$ & $\begin{array}{l}\text { Venegas et } \\
\text { al., } 2015\end{array}$ \\
\hline $\begin{array}{l}\text { Several } \\
\text { European } \\
\text { Countries } \\
\text { (France, } \\
\text { Spain, } \\
\text { Sweden, } \\
\text { UK) }\end{array}$ & $\begin{array}{l}\text { Municipal and hospital } \\
\text { sewage }\end{array}$ & Human & 108 & $100 \%$ & $\begin{array}{c}1.0 \mathrm{E}+04 \\
(5.0 \mathrm{E}+01 \text { to } 3.6 \mathrm{E}+05)\end{array}$ & $\begin{array}{l}\text { Blanch et al., } \\
2006\end{array}$ \\
\hline $\begin{array}{l}\text { Several } \\
\text { European } \\
\text { Countries } \\
\text { (France, } \\
\text { Spain, } \\
\text { Sweden, } \\
\text { UK) }\end{array}$ & $\begin{array}{c}\text { Abattoir wastewater and } \\
\text { slurries }\end{array}$ & Animal & 110 & $100 \%$ & $\begin{array}{c}3.1 \mathrm{E}+03 \\
(5.0 \mathrm{E}+01 \text { to } 1.0 \mathrm{E}+06)\end{array}$ & $\begin{array}{l}\text { Blanch et al., } \\
2006\end{array}$ \\
\hline Thailand & Municipal sewage & Human & 71 & $100 \%$ & $(1.4 \mathrm{E}+02$ to $1.4 \mathrm{E}+05)$ & $\begin{array}{l}\text { Sirikanchana } \\
\text { et al., } 2014\end{array}$ \\
\hline Tunisia & Municipal sewage & Human & 15 & $100 \%$ & $\begin{array}{c}\text { Median } \mathrm{E}+04 \\
(1.0 \mathrm{E}+02 \text { to } 1.7 \mathrm{E}+05)\end{array}$ & $\begin{array}{l}\text { Yahya et al., } \\
2015\end{array}$ \\
\hline Tunisia & Abattoir wastewater & Animal & 9 & $100 \%$ & $\begin{array}{c}\text { Median } 2.5 \mathrm{E}+04 \\
(1.0 \mathrm{E}+02 \text { to } 3.0 \mathrm{E}+05)\end{array}$ & $\begin{array}{c}\text { Yahya et al., } \\
2015\end{array}$ \\
\hline
\end{tabular}

${ }^{a}$ Method for all studies ISO 107 05-4 with host strain B. fragilis RYC2056

Lucena et al. (2003) detected strain RYC2056 phages in $77 \%$ of samples from twenty-eight septic tank samples in Argentina with counts ranging from $10^{2}$ to $10^{3} \mathrm{PFU} / 100 \mathrm{~mL}$. The lower numbers of Bacteroidesstrain RYC2056 phages compared to coliphages in the source of contamination, and the anaerobic conditions required for their cultivation, tend to discourage the use of RYC2056 phages as general indicator, at least in temperate climates, despite attractive features.

Table 13 shows counts of phages in wastewater of human origin obtained by using Bacteroides host strain GA and GB124 which yielded the highest counts in assays on hosts specific for human Bacteroides phages. 
Table 13. Concentrations of bacteriophages infecting Bacteroides host strains discerning the origin of contamination in raw wastewater

\begin{tabular}{|c|c|c|c|c|c|c|c|}
\hline Area & Host strain & $\begin{array}{l}\text { Sample type/ } \\
\text { Matrices }\end{array}$ & $\begin{array}{c}\text { Faecal } \\
\text { Source/ } \\
\text { Host } \\
\text { indicated }\end{array}$ & $\begin{array}{l}\text { Number } \\
\text { of } \\
\text { samples }\end{array}$ & $\begin{array}{l}\text { Percent } \\
\text { positive }\end{array}$ & $\begin{array}{l}\text { Concentration } \\
\text { Average (range) } \\
\text { PFU/100 mL }\end{array}$ & Reference \\
\hline Colombia & $\begin{array}{l}\text { B. thetaiotaomicron } \\
\text { GA17 }\end{array}$ & $\begin{array}{c}\text { Municipal } \\
\text { wastewater }\end{array}$ & Human & 5 & $100 \%$ & $\begin{array}{c}3.2 \mathrm{E}+04 \\
(1.0 \mathrm{E}+04 \text { to } 5.9 \mathrm{E}+05)\end{array}$ & $\begin{array}{l}\text { Venegas et } \\
\text { al., } 2015\end{array}$ \\
\hline Colombia & $\begin{array}{c}\text { B. thetaiotaomicron } \\
\text { GA17 }\end{array}$ & $\begin{array}{c}\text { Abattoir } \\
\text { wastewater }\end{array}$ & Animal & 4 & $0 \%$ & $<100$ all samples & $\begin{array}{l}\text { Venegas et } \\
\text { al., } 2015\end{array}$ \\
\hline $\begin{array}{l}\text { European } \\
\text { Countries } \\
\text { (France, } \\
\text { Spain, } \\
\text { Sweden, } \\
\text { UK) }\end{array}$ & $\begin{array}{l}\text { B. thetaiotaomicron } \\
\text { GA17 }\end{array}$ & $\begin{array}{c}\text { Municipal } \\
\text { wastewater }\end{array}$ & Human & 73 & $100 \%$ & $\begin{array}{c}1.5 \mathrm{E}+04 \\
(5.0 \mathrm{E}+01 \text { to } 7.0 \mathrm{E}+05)\end{array}$ & $\begin{array}{c}\text { Blanch et al., } \\
2006\end{array}$ \\
\hline $\begin{array}{l}\text { European } \\
\text { Countries } \\
\text { (France, } \\
\text { Spain, } \\
\text { Sweden, } \\
\text { UK) }\end{array}$ & $\begin{array}{l}\text { B. thetaiotaomicron } \\
\text { GA17 }\end{array}$ & $\begin{array}{c}\text { Abattoir } \\
\text { wastewater and } \\
\text { slurries }\end{array}$ & Animal & 71 & $7 \%$ & $\begin{array}{c}5.5 \mathrm{E}+01 \\
(<5.0 \mathrm{E}+01 \text { to } \\
1.0 \mathrm{E}+03) \\
\text { Only } 7 \% \text { of samples } \\
>50\end{array}$ & $\begin{array}{l}\text { Blanch et al., } \\
2006\end{array}$ \\
\hline Spain & $\begin{array}{c}\text { B. thetaiotaomicron } \\
\text { GA17 }\end{array}$ & $\begin{array}{c}\text { Municipal } \\
\text { wastewater }\end{array}$ & Human & 43 & $100 \%$ & $\begin{array}{c}5.9 \mathrm{E}+04 \\
(4.0 \mathrm{E}+03 \text { to } 3.5 \mathrm{E}+05)\end{array}$ & $\begin{array}{l}\text { Muniesa et } \\
\text { al., } 2012\end{array}$ \\
\hline Spain & $\begin{array}{c}\text { B. thetaiotaomicron } \\
\text { GA17 }\end{array}$ & $\begin{array}{c}\text { Abattoir } \\
\text { wastewater }\end{array}$ & Animal & 125 & $3.2 \%$ & $\begin{array}{c}(2.0 \mathrm{E}+01 \text { to } 2.0 \mathrm{E}+03) \\
\text { Only } 3.2 \% \text { of samples } \\
>50\end{array}$ & $\begin{array}{l}\text { Gómez-Doñate } \\
\text { et al., } 2011\end{array}$ \\
\hline Thailand & $\begin{array}{c}\text { B. thetaiotaomicron } \\
\text { GA17 }\end{array}$ & $\begin{array}{c}\text { Municipal } \\
\text { wastewater }\end{array}$ & Human & 71 & $0 \%$ & $<19$ & $\begin{array}{l}\text { Sirikanchana } \\
\text { et al., } 2014\end{array}$ \\
\hline Tunisia & $\begin{array}{c}\text { B. thetaiotaomicron } \\
\text { GA17 }\end{array}$ & $\begin{array}{c}\text { Municipal } \\
\text { wastewater }\end{array}$ & Human & 15 & $100 \%$ & $\begin{array}{c}1.0 \mathrm{E}+04 \\
(1.0 \mathrm{E}+03 \text { to } 1.7 \mathrm{E}+05)\end{array}$ & $\begin{array}{l}\text { Yahya et al., } \\
2015\end{array}$ \\
\hline Tunisia & $\begin{array}{c}\text { B. thetaiotaomicron } \\
\text { GA17 }\end{array}$ & $\begin{array}{c}\text { Abattoir } \\
\text { wastewater }\end{array}$ & Animal & 6 & $16 \%$ & $\begin{array}{c}(<1 \text { to } 1.0 \mathrm{E}+03) \\
\text { Only } 16 \% \text { of samples } \\
>100\end{array}$ & $\begin{array}{l}\text { Yahya et al., } \\
2015\end{array}$ \\
\hline UK & B. fragilis GB124 & Animal slurries & Animal & 30 & $0 \%$ & $<100$ & $\begin{array}{c}\text { Ebdon et al., } \\
2007\end{array}$ \\
\hline USA & B. fragilis GB124 & $\begin{array}{c}\text { Primary sewage } \\
\text { effluent }\end{array}$ & Human & 5 & $100 \%$ & $(2.0 \mathrm{E}+01$ to $3.8 \mathrm{E}+02)$ & $\begin{array}{l}\text { McMinn et al., } \\
2014\end{array}$ \\
\hline
\end{tabular}


Detection of phages by strains GA17, GB124 show a certain geographic discontinuity, which was previously appreciated for strain HSP40 (Kator and Rhodes, 1992; McLaughlin and Rose, 2006; Sirikanchana et al., 2014). In Southern Europe, Tunissia and Colombia, most phage concentrations detected by GA17 ranged between $5 \times 10^{4}$ and $5 \times 10^{5}$ PFUs/100 mL. McMinn et al. (2014) have reported values of phages detected by strain GB214 in primary sewage effluents studied in several states of USA with average values in some states well below $10^{3}$ to some states with average values nearby $10^{4} / 100 \mathrm{~mL}$.

As it happens with somatic and F-specific coliphages, the presence of phages infecting strains RYC2056 and GA17 in sewage shows no seasonality (Muniesa et al., 2012).

\subsection{Treated Wastewater}

Detailed information on phages as treatment indicators as well as on removal during treatment will be given in Using indicators to assess microbial treatment and disinfection efficacywithin this section and in chapters within the technology section. Here, data on phages found in different kinds of wastewater treatment effluents categorized as secondary are provided.

\subsubsection{Somatic coliphages}

Primary sedimentation, up flow anaerobic sludge blanket processes, flocculation-aided sedimentation, activated sludge digestion, activated sludge digestion plus precipitation and trickling filters remove bacterial indicators and somatic coliphages in numbers ranging from 0.3 to $3.0 \log _{10}$. Differences in the elimination of faecal indicator bacteria and somatic coliphages are minor and vary slightly from treatment to treatment. Therefore, the values of somatic coliphages in secondary effluents range mostly from $10^{3}$ to $10^{5} \mathrm{PFU} / 100 \mathrm{~mL}$ (Table 14).

Table 14. Concentrations of somatic coliphages in secondary activated sludge effluents (faecal source humans)

\begin{tabular}{|c|c|c|c|c|c|c|}
\hline Area & Host strain & Detection Method & $\begin{array}{l}\text { Number of } \\
\text { samples }\end{array}$ & $\begin{array}{l}\text { Percent } \\
\text { positive }\end{array}$ & $\begin{array}{c}\text { Concentration } \\
\text { Average (range) } \\
\text { PFU/100 mL }\end{array}$ & Reference \\
\hline Canada & E. coli C & $\begin{array}{l}\text { APHA previous 22nd } \\
\text { edition }\end{array}$ & - & $100 \%$ & $\begin{array}{c}(2.0 \mathrm{E}+02 \text { to } \\
1.0 \mathrm{E}+03)\end{array}$ & $\begin{array}{c}\text { Zhang and } \\
\text { Farahbakhsh, } \\
2007\end{array}$ \\
\hline China & E. coli WG5 & ISO $10705-2$ & 14 & $100 \%$ & $\begin{array}{c}9.4 \mathrm{E}+03 \\
(1.0 \mathrm{E}+03 \text { to } \\
4.9 \mathrm{E}+04)\end{array}$ & Fu et al., 2010 \\
\hline Netherlands & E. coli WG5 & ISO $10705-2$ & 5 & $100 \%$ & $\begin{array}{c}2.2 E+04 \\
(2.5 E+04 \text { to } \\
1.1 E+05)\end{array}$ & $\begin{array}{l}\text { Lodder and de } \\
\text { Roda Husman, } \\
\quad 2005\end{array}$ \\
\hline $\begin{array}{l}\text { South } \\
\text { Africa }\end{array}$ & E. coli WG5 & ISO $10705-2$ & 12 & $100 \%$ & $\begin{array}{c}2.9 \mathrm{E}+03 \\
(7.0 \mathrm{E}+02 \text { to } \\
6.8 \mathrm{E}+04)\end{array}$ & $\begin{array}{c}\text { Grabow et al., } \\
1993\end{array}$ \\
\hline Spain & E. coli WG5 & ISO $10705-2$ & 48 & $100 \%$ & $1.6 \mathrm{E}+05$ & $\begin{array}{l}\text { Costán-Longares } \\
\text { et al., } 2008\end{array}$ \\
\hline Spain & E. coli WG5 & ISO $10705-2$ & 8 & $100 \%$ & $\begin{array}{c}7.8 \mathrm{E}+05 \\
(4.5 \mathrm{E}+02 \text { to } \\
2.3 \mathrm{E}+07)\end{array}$ & $\begin{array}{l}\text { Gomila et al., } \\
2008\end{array}$ \\
\hline Tunisia & E. coli WG5 & ISO $10705-2$ & 15 & $100 \%$ & $\begin{array}{c}\text { Median } 6.0 \mathrm{E}+04 \\
(1.2 \mathrm{E}+04 \text { to } \\
7.2 \mathrm{E}+04)\end{array}$ & $\begin{array}{l}\text { Yahya et al., } \\
2015\end{array}$ \\
\hline
\end{tabular}


Another point source is the effluents of waste stabilization ponds (or oxidation ponds, or lagoons) of very varied configuration and extent of treatment. Therefore, the effluents released after lagooning are quite diverse regarding the concentration of indicators (Alcalde et al., 2003; Campos et al., 2002; Gomila et al., 2008; Lucena et al., 2004). Moreover, counts of indicators in the effluents can vary between seasons in climates with marked seasonal variation.

DeBorde et al. (1998) studied the septic effluents of a high school in the USA and detected somatic coliphages in all 43 samples tested with values between $10^{4}$ and $10^{5} \mathrm{PFU} / 100 \mathrm{~mL}$, though in this case the host strains used were not those recommended in the standardized methods.

\subsubsection{F-specific and F-specific RNA bacteriophages}

Primary sedimentation, up flow anaerobic sludge blanket processes, flocculation-aided sedimentation, activated sludge digestion, activated sludge digestion plus precipitation and trickling filters remove bacterial indicators, somatic coliphages, F-specific and F-specific RNA phages in numbers ranging from 0.3 to $3.0 \log _{10}$. The reported values of F-specific and F-specific RNA phages in secondary effluents range mostly from $10^{2}$ to $10^{4} \mathrm{PFU} / 100$ $\mathrm{mL}$ (Table 15). The relative proportions of the F-specific and F-specific RNA phages with other indicators remain similar to those in untreated wastewater.

Table 15. Concentrations of F-specific and F-specific RNA phages in activated sludge secondary effluents (Faecal sources human)

\begin{tabular}{|c|c|c|c|c|c|c|c|}
\hline Area & $\begin{array}{c}\text { Indicator/Marker } \\
\text { Name }\end{array}$ & Host strain & $\begin{array}{c}\text { Detection } \\
\text { Method }\end{array}$ & $\begin{array}{c}\text { Numbers } \\
\text { of } \\
\text { samples } \\
\end{array}$ & $\begin{array}{l}\text { Percent } \\
\text { positive } \\
\end{array}$ & $\begin{array}{c}\text { Concentration } \\
\text { Average (range) } \\
\text { PFU/100 mL } \\
\end{array}$ & Reference \\
\hline Canada & F-specific phages & $\begin{array}{c}S . \\
\text { typhimurium } \\
\text { WG49 }\end{array}$ & $\begin{array}{c}\text { ISO } \\
10705-1\end{array}$ & 10 & $100 \%$ & $\begin{array}{c}(5.0 \mathrm{E}+02 \text { to } \\
1.0 \mathrm{E}+03)\end{array}$ & $\begin{array}{c}\text { Zhang and } \\
\text { Farahbakhsh, } \\
2007\end{array}$ \\
\hline Japan & F-specific phages & $\begin{array}{c}S . \\
\text { typhimurium } \\
\text { WG49 }\end{array}$ & $\begin{array}{c}\text { ISO } \\
10705-1\end{array}$ & 24 & $100 \%$ & $1.0 \mathrm{E}+04$ & Hata et al., 2013 \\
\hline Netherlands & F-specific phages & $\begin{array}{c}S . \\
\text { typhimurium } \\
\text { WG49 }\end{array}$ & $\begin{array}{c}\text { ISO } \\
10705-1\end{array}$ & 5 & $100 \%$ & $\begin{array}{c}4.8 \mathrm{E}+04 \\
(5.3 \mathrm{E}+03 \text { to } \\
1.2 \mathrm{E}+05)\end{array}$ & $\begin{array}{l}\text { Lodder and de } \\
\text { Roda Husman, } \\
\quad 2005\end{array}$ \\
\hline $\begin{array}{l}\text { South } \\
\text { Africa }\end{array}$ & F specific phages & $\begin{array}{c}\text { S. } \\
\text { typhimurium } \\
\text { WG49 }\end{array}$ & $\begin{array}{c}\text { ISO } \\
10705-1\end{array}$ & 12 & $100 \%$ & $\begin{array}{c}1.6 \mathrm{E}+03 \\
(1.0 \mathrm{E}+02 \text { to } \\
3.6 \mathrm{E}+03)\end{array}$ & $\begin{array}{c}\text { Grabow et al., } \\
1993\end{array}$ \\
\hline Spain & $\begin{array}{c}\text { F-specific RNA } \\
\text { phages }\end{array}$ & $\begin{array}{c}\text { S. } \\
\text { typhimurium } \\
\text { WG49 }\end{array}$ & $\begin{array}{c}\text { ISO } \\
10705-1\end{array}$ & 8 & $84.2 \%$ & $\begin{array}{l}6.8 \mathrm{E}+04 \\
(<100 \text { to } \\
1.5 \mathrm{E}+05)\end{array}$ & $\begin{array}{c}\text { Gomila et al., } \\
2008\end{array}$ \\
\hline Spain & $\begin{array}{c}\text { F-specific RNA } \\
\text { phages }\end{array}$ & $\begin{array}{c}S . \\
\text { typhimurium } \\
\text { WG49 }\end{array}$ & $\begin{array}{c}\text { ISO } \\
10705-1\end{array}$ & 48 & $100 \%$ & $1.2 \mathrm{E}+04$ & $\begin{array}{c}\text { Costán-Longares } \\
\text { et al., } 2008\end{array}$ \\
\hline Tunisia & $\begin{array}{c}\text { F-specific RNA } \\
\text { phages }\end{array}$ & $\begin{array}{c}S . \\
\text { typhimurium } \\
\text { WG49 }\end{array}$ & $\begin{array}{c}\text { ISO } \\
10705\end{array}$ & 15 & $100 \%$ & Median 1.0E +04 & $\begin{array}{l}\text { Yahya et al., } \\
2015\end{array}$ \\
\hline USA & F-specific phages & $\begin{array}{c}\text { E. coli } \\
\text { HS(pFamp)RR }\end{array}$ & $\begin{array}{l}\text { USEPA } \\
1602\end{array}$ & 14 & $79 \%$ & $\begin{array}{l}3.0 \mathrm{E}+04 \\
(<100 \text { to } \\
2.1 \mathrm{E}+05)\end{array}$ & $\begin{array}{l}\text { Calci et al., } \\
1998\end{array}$ \\
\hline $\begin{array}{l}\text { USA } \\
\text { (Hawaii) }\end{array}$ & $\begin{array}{c}\text { F-specific RNA } \\
\text { phages }\end{array}$ & $\begin{array}{c}S . \\
\text { typhimurium } \\
\text { WG49 }\end{array}$ & $\begin{array}{c}\text { ISO } \\
10705-1\end{array}$ & 4 & NR & $8.5 E+03$ & $\begin{array}{c}\text { Luther and } \\
\text { Fujioka, } 2004\end{array}$ \\
\hline
\end{tabular}

NR - Not Reported 
As in the case of somatic coliphages, the concentrations of F-specific phages detected in effluents released by lagooning are quite variable. In climates with marked seasonal variation the numbers of pathogens and indicators in the effluents may vary between summer and winter in the same treatment facility (Alcalde et al., 2003; Gomila et al., 2008; Hill and Sobsey, 1998; Lucena et al., 2004).

DeBorde et al. (1998) studied the septic effluents of a high school (350 persons) in the USA and detected Fspecific phages in all 43 samples tested with values ranging from $10^{4}$ to $10^{5} / 100 \mathrm{~mL}$, though this number might be an overestimation since the host strain used in this study, C3000, detects also somatic coliphages.
In secondary effluents of municipal activated sludge plants, there is a very significant increase in the percentage of subgroup I and the practical disappearance of subgroup IV(Table 11). This has been observed after either subgrouping of plaques or by direct determination of GC copies.

\subsubsection{Bacteriophages infecting Bacteroides}

Numbers of Bacteroides phages in secondary effluents range mostly from $5 \times 10$ to $10^{4} \mathrm{PFU} / 100 \mathrm{~mL}($ Table 16$)$. The relative proportions of the Bacteroides phages with other indicators remain similar to those in untreated wastewater.

Table 16. Concentrations of bacteriophages infecting Bacteroides host strains discerning the origin of contamination in activated sludge secondary effluents (faecal source human)

\begin{tabular}{|c|c|c|c|c|c|}
\hline Area & Host strain & Number of samples & Percent positive & $\begin{array}{c}\text { Concentration }^{\mathrm{a}} \\
\text { Average (range) } \\
\text { PFU/100 mL } \\
\end{array}$ & Reference \\
\hline Spain & $\begin{array}{c}B . \\
\text { thetaiotaomicron } \\
\text { GA17 }\end{array}$ & 33 & $100 \%$ & $\begin{array}{l}\text { Median } 3.0 \mathrm{E}+03 \\
(50 \text { to } 7 \mathrm{E}+04)\end{array}$ & $\begin{array}{c}\text { Muniesa et } \\
\text { al., } 2012\end{array}$ \\
\hline Spain & $\begin{array}{c}B . \\
\text { thetaiotaomicron } \\
\text { GA17 }\end{array}$ & 73 & $75.3 \%$ & $\begin{array}{c}4.1 \mathrm{E}+03 \\
(<50 \text { to } 3.6 \mathrm{E}+05)\end{array}$ & $\begin{array}{l}\text { Gomila et } \\
\text { al., } 2008\end{array}$ \\
\hline Tunisia & $\begin{array}{c}B . \\
\text { thetaiotaomicron } \\
\text { GA17 }\end{array}$ & $6 b$ & $0 \%$ & $<100$ & $\begin{array}{l}\text { Yahya et } \\
\text { al., } 2015\end{array}$ \\
\hline Tunisia & $\begin{array}{c}B . \\
\text { thetaiotaomicron } \\
\text { GA17 }\end{array}$ & 15 & $100 \%$ & $\begin{array}{c}\text { Median } 2.9 \mathrm{E}+02 \\
\text { (21 to } 7.0 \mathrm{E}+03)\end{array}$ & $\begin{array}{l}\text { Yahya et } \\
\text { al., } 2015\end{array}$ \\
\hline $\begin{array}{l}\text { UK and } \\
\text { Denmark }\end{array}$ & B. fragilis GB124 & 110 & $100 \%$ & $\begin{array}{c}8.5 \mathrm{E}+03 \\
(1.0 \mathrm{E}+02 \text { to } \\
5.0 \mathrm{E}+04)\end{array}$ & $\begin{array}{l}\text { Ebdon et } \\
\text { al., } 2007\end{array}$ \\
\hline
\end{tabular}

${ }^{\mathrm{a}}$ Detection method ISO10705-4; ${ }^{\mathrm{b}}$ Slaughterhouse

As in the case of somatic coliphages, the numbers of Bacteroides phages in lagoon effluents are quite variable. In climates with marked seasonal variation the quality of the effluents depends on the season (Campos et al., 2002; Gomila et al., 2008; Lucena et al., 2004).

\subsection{Untreated Sludge}

\subsubsection{Somatic coliphages}

The numbers of reports about concentrations of somatic coliphages in untreated sludge (primary sludge, raw sludge (mix of primary and activated), activated sludge and thickened sludge) are relatively scarce as compared to reports on phages in treated sludge. Most of the reported results are summarized inTable 17. Somatic coliphages were detected in all samples tested. Though concentrations in the different reports are difficult to compare since the concentrations reported in the scientific literature are referred to different measures such as dry mass, wet mass and volumes, and since different extraction procedures have been used, their concentrations are quite high in all reports. The highest concentrations are reported in primary sludge and the lowest in activated sludge. Numbers above $10^{7} \mathrm{PFU} / \mathrm{gram}$ of dry weight have been reported for primary and raw sludge. Their counts in sludge remain in proportion to those of bacterial faecal indicators and other phages in raw wastewater. 
Table 17. Concentrations of somatic coliphages in untreated sludge from a municipal wastewater treatment plant (faecal source human)

\begin{tabular}{|c|c|c|c|c|c|c|}
\hline Area & Host strain & Detection Method & $\begin{array}{l}\text { Number of } \\
\text { samples }\end{array}$ & $\begin{array}{l}\text { Percent } \\
\text { positive }\end{array}$ & $\begin{array}{c}\text { Concentration }^{\mathrm{a}} \text { Average } \\
\text { (range) }\end{array}$ & Reference \\
\hline Canada & E. coli C & $\begin{array}{l}\text { APHA previous } \\
\text { 22nd edition }\end{array}$ & 10 & $100 \%$ & $\begin{array}{c}1.7 \mathrm{E}+06 / 100 \mathrm{~g} \\
\text { of wet matter }\end{array}$ & $\begin{array}{l}\text { Chauret et } \\
\text { al., } 1999\end{array}$ \\
\hline Colombia & E. coli WG5 & ISO10705-2 & 12 & $100 \%$ & $\begin{array}{l}1.5 \mathrm{E}+07 / 100 \mathrm{~g} \\
\text { of dry matter }\end{array}$ & $\begin{array}{l}\text { Campos et } \\
\text { al., } 2013\end{array}$ \\
\hline Greece & E. coli WG5 & ISO10705-2 & 40 & $100 \%$ & $\begin{array}{l}1.0 \mathrm{E}+07 / 100 \mathrm{~g} \\
\text { of wet matter }\end{array}$ & $\begin{array}{c}\text { Mandilara } \\
\text { et al., } \\
2006\end{array}$ \\
\hline Spain & E. coli WG5 & ISO10705-2 & 6 & $100 \%$ & $\begin{array}{l}3.5 \mathrm{E}+09 / 100 \mathrm{~g} \\
\text { of dry matter }\end{array}$ & $\begin{array}{l}\text { Guzmán et } \\
\text { al., } 2007\end{array}$ \\
\hline Spain & E. coli WG5 & ISO10705-2 & 10 & $100 \%$ & $\begin{array}{l}1.1 \mathrm{E}+07 / 100 \mathrm{~g} \\
\text { of wet matter }\end{array}$ & $\begin{array}{c}\text { Lasobras } \\
\text { et al., } \\
1999\end{array}$ \\
\hline Spain & E. coli WG5 & ISO10705-2 & 10 & $100 \%$ & $\begin{array}{l}1.1 \mathrm{E}+06 / 100 \mathrm{~g} \\
\text { of wet matter }\end{array}$ & $\begin{array}{c}\text { Lasobras } \\
\text { et al., } \\
1999\end{array}$ \\
\hline Tunisia & E. coli WG5 & ISO10705-2 & 15 & $100 \%$ & $\begin{array}{c}\text { Median } \\
1.0 \mathrm{E}+06 / 100 \mathrm{~mL}\end{array}$ & $\begin{array}{l}\text { Yahya et } \\
\text { al., } 2015\end{array}$ \\
\hline Tunisia & E. coli WG5 & ISO10705-2 & 6 & $100 \%$ & $\begin{array}{c}\text { Median } \\
1.0 \mathrm{E}+06 / 100 \mathrm{~mL}\end{array}$ & $\begin{array}{l}\text { Yahya et } \\
\text { al., } 2015\end{array}$ \\
\hline
\end{tabular}

${ }^{a}$ PFU per mass or volume as indicated in the cells

\subsubsection{F-specific and F-specific RNA bacteriophages}

The same general comments done for somatic coliphages in untreated sludge mentioned earlier apply for F-specific RNA phages. Most of the reported results regarding untreated sludge are summarized inTable 18. Fspecific RNA phages were detected in all samples tested.
As in raw and treated wastewater they rank second in abundance among the indicator phages. The highest numbers were reported in primary sludge and the lowest in activated sludge. Concentrations well over $10^{6} \mathrm{PFU} / \mathrm{gram}$ of dry weight have been reported for primary and raw sludge. Their concentration in sludge and proportion to faecal bacteria and other phages remain similar to that in raw wastewater.

Table 18. Concentrations of F-specific and F-specific RNA phages in untreated sludge from municipal wastewater treatment plant(faecal source human)

\begin{tabular}{|c|c|c|c|c|c|c|}
\hline Area & Indicator/Marker Name & $\begin{array}{c}\text { Target Organism } \\
\text { /Gene }\end{array}$ & $\begin{array}{c}\text { Number of } \\
\text { samples }\end{array}$ & $\begin{array}{l}\text { Percentage } \\
\text { positives }\end{array}$ & $\begin{array}{c}\text { Concentration }^{\mathrm{a}} \\
\text { Average } \\
\text { (range) }\end{array}$ & Reference \\
\hline Greece & $\begin{array}{l}\text { F-specific } \\
\text { phages }\end{array}$ & $\begin{array}{l}\text { S. typhimurium } \\
\text { WG49 }\end{array}$ & 40 & $100 \%$ & $\begin{array}{c}1.0 \mathrm{E}+06 \text { to } \\
1.0 \mathrm{E}+07) / 100 \mathrm{~g} \\
\text { of wet matter }\end{array}$ & $\begin{array}{l}\text { Mandilara } \\
\text { et al., } \\
2006\end{array}$ \\
\hline Spain & $\begin{array}{c}\text { F-specific } \\
\text { RNA phages }\end{array}$ & $\begin{array}{l}\text { S. typhimurium } \\
\text { WG49 }\end{array}$ & 6 & $100 \%$ & $\begin{array}{c}1.2 \mathrm{E}+09 / 100 \mathrm{~g} \\
\text { of dry matter }\end{array}$ & \multirow{2}{*}{$\begin{array}{c}\text { Guzmán et } \\
\text { al., } 2007 \\
\text { Lasobras } \\
\text { et al., } \\
1999\end{array}$} \\
\hline Spain & $\begin{array}{c}\text { F-specific } \\
\text { RNA phages }\end{array}$ & $\begin{array}{l}\text { S. typhimurium } \\
\text { WG49 }\end{array}$ & 10 & $100 \%$ & $\begin{array}{l}4.4 \mathrm{E}+06 / 100 \mathrm{~g} \\
\text { of wet matter }\end{array}$ & \\
\hline Spain & $\begin{array}{c}\text { F-specific } \\
\text { RNA phages }\end{array}$ & $\begin{array}{c}\text { E. coli } \\
\text { HS(pFamp)RR }\end{array}$ & 10 & $100 \%$ & $\begin{array}{l}1.6 \mathrm{E}+05 / 100 \mathrm{~g} \\
\text { of wet matter }\end{array}$ & $\begin{array}{l}\text { Lasobras } \\
\text { et al., } \\
1999\end{array}$ \\
\hline Tunisia & $\begin{array}{c}\text { F-specific } \\
\text { RNA phages }\end{array}$ & $\begin{array}{l}\text { S. typhimurium } \\
\text { WG49 }\end{array}$ & 15 & $100 \%$ & $\begin{array}{c}\text { Median } \\
5 \mathrm{E}+04 / 100 \mathrm{~mL}\end{array}$ & $\begin{array}{l}\text { Yahya et } \\
\text { al., } 2015\end{array}$ \\
\hline
\end{tabular}

${ }^{\text {a }}$ PFU per mass or volume as indicated in the cells, Detection method ISO 10705-1 
Phages in plaques obtained from municipal untreated sludge gave the following distribution: $56 \%$ of serogroup I, $38 \%$ of group II and $6 \%$ had a mixed population. This pattern resembles that of secondary effluents more closely than that of raw wastewater (Nappier et al., 2006).

\subsubsection{Bacteriophages infecting Bacteroides}

The same general comments made for somatic coliphages in non-treated sludges apply to Bacteroides phages. Most of the reported results regarding non-treated sludge are summarized inTable 19. As in raw and treated wastewater they rank third in abundance among the indicator phages. Bacteroides phages were detected in all samples tested when the matching (faecal source and geographic area) host strain was used. Highest counts were reported in primary sludge and the lowest in activated sludge. Concentrations well over $10^{4} \mathrm{PFU} / \mathrm{gram}$ of dry weight have been reported for primary and raw sludge. Their numbers in sludge and proportion to faecal bacterial and other phages remained similar to that in raw wastewater.

Table 19. Concentrations of bacteriophages infecting Bacteroides host strains discerning the origin of contamination in untreated sludge from municipal wastewater treatment plants (faecal source human)

\begin{tabular}{lcccc}
\hline Area & Number of samples & Percentage positive & $\begin{array}{c}\text { Concentration }{ }^{\text {a }} \\
\text { Average (range) } \\
\text { PFU/100 mL liquid sludge }\end{array}$ & Reference \\
\hline Spain & 12 & $100 \%$ & $\begin{array}{c}\text { Median } 5.0 \mathrm{E}+05 \\
(2.0 \mathrm{E}+05 \text { to } 7.0 \mathrm{E}+05) \\
\text { Median } 4.0 \mathrm{E}+03\end{array}$ & $\begin{array}{c}\text { Muniesa et } \\
\text { al., 2012 }\end{array}$ \\
Tunisia & 15 & $100 \%$ & $\begin{array}{c}\text { Yahya et } \\
\text { al., 2015 }\end{array}$
\end{tabular}

${ }^{a}$ Detection method ISO10705-4 with B. thetaiotaomicron GA17 host

\subsection{Persistence}

Persistence of pathogens and indicators in water environments depends on both external factors related to water condition and in the microbe itself. Each microbe behaves differently. In the case of viruses and phages even simple mutations can change the resistance to treatment and persistence in the environment (Wigginton and Kohn, 2012). Because of this, model experiments with viruses and phages adapted to grow in laboratory culture should be viewed cautiously.

Most available data on phage persistence determined in model experiments refer to laboratory grown model phages and will be reviewed in more detail in the persistence section.

\subsection{General Indicator Bacteriophages}

Coliphages are present in raw sewage in numbers high enough to carry out model inactivation experiments after diluting sewage in fresh, brackish or marine water. In contrast, concentrations of phages infecting Bacteroides in raw sewage are not high enough to perform in situ experiments like hose reported for coliphages and consequently phages grown in the laboratory have to be inoculated into the mixture. The short discussion in this chapter is predominantly on coliphages naturally occurring in sewage and laboratory grown phages infecting Bacteroides and correspond to experiments in which the persistence of the three groups of phages was studied at once. The results show that indicator phages persist in water environments for longer than E. coli does (Table 20). 
Table 20. Persistence of the different groups of bacteriophages.

\begin{tabular}{|c|c|c|c|c|c|c|c|c|}
\hline $\begin{array}{c}\text { Assay } \\
\text { characteristics }\end{array}$ & $\begin{array}{c}\text { Habitat } \\
\text { description }\end{array}$ & $\begin{array}{l}\text { Physical } \\
\text { features }\end{array}$ & $\begin{array}{c}\text { Additional } \\
\text { experimental } \\
\text { conditions }\end{array}$ & $\begin{array}{c}\text { T90 } \\
\text { in } \\
\text { hours } \\
\text { E. } \\
\text { coli } \\
\text { /FC } \\
\end{array}$ & $\begin{array}{c}\text { T90 in } \\
\text { hours } \\
\text { Somatic } \\
\text { coliphages }\end{array}$ & $\begin{array}{c}\text { T90 in } \\
\text { hours } \\
\text { F-specific } \\
\text { RNA } \\
\text { phages }\end{array}$ & $\begin{array}{c}\text { T90 in } \\
\text { hours } \\
\text { Bacteroides } \\
\text { phages }\end{array}$ & References \\
\hline $\begin{array}{l}\text { "In situ" } \\
\text { inactivation in a } \\
560-600 \mathrm{~mm} \\
\text { depth (300 L) } \\
\text { open-top } \\
\text { chambers (A) }\end{array}$ & River water & $\begin{array}{c}\text { Winter } \\
\left(12^{\circ} \mathrm{C}\right) \text { and } \\
\text { dark }\end{array}$ & $\begin{array}{l}3 \% \text { v/v sewage } \\
\text { and river water } \\
\text { (C) }\end{array}$ & 100 & 2303 & $>2300$ & NR & $\begin{array}{c}\text { Sinton et al., } \\
2002\end{array}$ \\
\hline A & River water & $\begin{array}{l}\text { Winter } \\
\left(12^{\circ} \mathrm{C}\right) \text { and } \\
\text { sunlight }\end{array}$ & $\mathrm{C}$ & 6.9 & 15.9 & 19.1 & NR & $\begin{array}{c}\text { Sinton et al., } \\
2002\end{array}$ \\
\hline A & River water & $\begin{array}{l}\text { Summer } \\
(16 \%) \text { and } \\
\text { sunlight }\end{array}$ & $\mathrm{C}$ & 3.3 & 8.3 & 12.5 & NR & $\begin{array}{c}\text { Sinton et al., } \\
2002\end{array}$ \\
\hline A & Sea water & $\begin{array}{l}\text { Winter } \\
\left(12^{\circ} \mathrm{C}\right) \text { and } \\
\text { dark }\end{array}$ & $\begin{array}{c}2 \% \mathrm{v} / \mathrm{v} \text { sewage } \\
\text { and sea } \\
\text { water(D) }\end{array}$ & 63 & 102 & 156 & NR & $\begin{array}{c}\text { Sinton et al., } \\
1999\end{array}$ \\
\hline A & Sea water & $\begin{array}{l}\text { Winter } \\
\left(12^{\circ} \mathrm{C}\right) \text { and } \\
\text { sunlight }\end{array}$ & $\mathrm{D}$ & 7.7 & 51.3 & 20.3 & NR & $\begin{array}{c}\text { Sinton et al., } \\
1999\end{array}$ \\
\hline A & Sea water & $\begin{array}{l}\text { Summer } \\
\left(16^{0} C\right) \text { and } \\
\text { dark }\end{array}$ & $\mathrm{D}$ & 49 & 52 & 52 & $257^{\mathrm{a}}$ & $\begin{array}{c}\text { Sinton et al., } \\
1999\end{array}$ \\
\hline A & Sea water & $\begin{array}{l}\text { Summer } \\
\left(16^{\circ} C\right) \text { and } \\
\text { sunlight }\end{array}$ & $\mathrm{D}$ & 1.7 & 7 & 4.8 & $4.3^{\mathrm{a}}$ & $\begin{array}{c}\text { Sinton et al., } \\
1999\end{array}$ \\
\hline $\begin{array}{l}\text { Sample in sealed } \\
\text { dialysis tube } \\
\text { placed "in situ" at } \\
\text { a } 20-25 \mathrm{~cm} \text { depth } \\
\text { placed (B) }\end{array}$ & River water & $\begin{array}{l}\text { Summer } \\
\left(20-25^{\circ} \mathrm{C}\right) \\
\text { and } \\
\text { sunlight }\end{array}$ & $\begin{array}{l}2 \% \mathrm{v} / \mathrm{v} \text { sewage } \\
\text { and river water }\end{array}$ & 64 & 118 & 62 & $>118^{\mathrm{a}}$ & $\begin{array}{l}\text { Durán et al., } \\
2002\end{array}$ \\
\hline B & River water & $\begin{array}{l}\text { Winter } \\
\left(6-10^{\circ} \mathrm{C}\right) \\
\text { and } \\
\text { sunlight }\end{array}$ & $\begin{array}{l}2 \% \mathrm{v} / \mathrm{v} \text { sewage } \\
\text { and river water }\end{array}$ & 233 & 385 & 323 & $>385^{\mathrm{a}}$ & $\begin{array}{l}\text { Durán et al., } \\
2002\end{array}$ \\
\hline B & Sea water & $\begin{array}{l}\text { Summer } \\
\left(>25^{\circ} \mathrm{C}\right)\end{array}$ & $\begin{array}{l}2 \% \mathrm{v} / \mathrm{v} \text { sewage } \\
\text { and sea water }\end{array}$ & 9.8 & 53 & 14 & $95^{\mathrm{a}}$ & $\begin{array}{l}\text { Mocé-Llivina } \\
\text { et al., } 2003\end{array}$ \\
\hline $\begin{array}{l}\text { Wetland } \\
\text { sediments } \\
\text { (naturally } \\
\text { occurring) }\end{array}$ & $\begin{array}{l}\text { Wetland } \\
\text { sediments }\end{array}$ & NR & NR & 27 & 370 & NR & NR & $\begin{array}{l}\text { Stenström } \\
\text { and } \\
\text { Carlander, } \\
2001\end{array}$ \\
\hline
\end{tabular}

NR - Not Reported

${ }^{a}$ Laboratory grown phages were spiked in the mixture

Indirect information regarding comparative persistence is also provided by the changes of the ratios between the numbers of conventional bacterial indicators and phages in water environments with aged pollution. Different studies report a decrease of the ratio in both river and marine waters when compared to the ratios of sewage (ContrerasColl et al., 2002; Ibarluzea et al., 2007; Lucena et al., 2003; Mocé-Llivina et al., 2005; Skraber et al., 2002). This diminution confirms the observation of the model experiments.

As a whole, it can be concluded that persistence of the three groups of indicator phages is intermediate and as reviewed by Verbyla and Mihelcic (Verbyla and Mihelcic, 2014) their persistence is in the range of that of human viruses.

We think that it is worth mentioning that the great 
majority of data regarding the presence and persistence of F-specific RNA phages as a group in water have been obtained in cold and temperate climates. But, evidences exist indicating that in environments with temperatures higher than $25^{\circ} \mathrm{C}$ F-specific RNA phages persist shorter than the other phages and bacterial indicators (AgullóBarceló et al., 2013; Alcalde et al., 2003; Cole et al., 2003; Durán et al., 2002; Guzmán et al., 2007; Mandilara et al., 2006; Mocé-Llivina et al., 2005). Geographic areas with surface sea and fresh water temperatures over $25^{\circ} \mathrm{C}$ either all year round (between $40^{\circ}$ latitude North and $40^{\circ}$ latitude South) or during the warm seasons (many areas of Europe and USA) are quite extensive. Then, the persistence of Fspecific and F-specific RNA phages needs some extra verification before rating their persistence and recommending their use in warm regions.

\subsection{Host Specific Indicator Bacteriophages}

Many experiments regarding persistence of F-specific RNA subgroups in the water environment indicate a significant difference in the persistence among the subgroups. Indeed, persistence studies with phage isolates belonging to the different subgroups (Cole et al., 2003; Schaper et al., 2002a) and with naturally occurring phages (Hartard et al., 2015; Muniesa et al., 2009) indicate differential persistence between subgroups. In all cases subgroup I being the more persistent followed by subgroups II, III and IV in this order. These diverse survival rates of subgroups of F-specific RNA phages to environmental stressors constitute a limitation to their suitability as trackers of the origin of faecal pollution. This fact is aggravated by a similar behaviour in advanced wastewater treatments. All together these features lead to a marked preponderance of subgroup I in surface waters (Brion et al., 2002; Cole et al., 2003; Stewart-Pullaro et al., 2006).

All the results obtained in the in situ experiments point out that phages infecting different host strains of Bacteroides, including those that allow tracking faecal sources, are more persistent than E. coli and are in the range of persistence of somatic coliphages. Regarding the ratios between numbers of different indicators, Muniesa et al. (2012) reported that the numerical ratios between somatic coliphages/phages infecting Bacteroides strains in wastewaters are maintained in river and marine water. This fact points out that the persistence of phages infecting Bacteroides is similar to that of somatic coliphages. Having this in mind, Muniesa et al. (2012) have suggested that the numerical ratios between the concentrations of somatic coliphages and other phages detected by strains able to identify host associated faecal contaminant are a good marker for microbial source tracking.

\subsection{Short Review on the Application of Phage as Indicators}

\subsection{General Quality Indicators}

Coliphages have been used in academia for many years as both faecal and viral indicators. The high concentrations found in raw wastewaters and in many other matrixes contaminated with faecal remains, the easy, fast and cost effective methods, the persistence in the water environment and the resistance to treatments (see chapters dealing with sanitation, disinfection and persistence), which resemble those of viruses, make the indicator phages good surrogate indicator candidates for various set-ups.

Additionally, regulatory authorities in different areas of the world are beginning to consider phages as indicators of water quality and for validating and verifying water treatment processes.

\subsubsection{Quality indicators of recreational waters}

A substantial amount of data about the presence and levels of indicator phages, mostly coliphages, in all type of surface waters and in very different climatic areas is available (Burbano-Rosero et al., 2011; Contreras-Coll et al., 2002; Ebdon et al., 2007; Haramoto et al., 2005; Ibarluzea et al., 2007; Jiang et al., 2007; Lucena et al., 2003; Rezaeinejad et al., 2014; Taylor et al., 2001). The general trend is that the three groups of phages keep the same proportions as in raw wastewater, but they have reduced the concentration gap with either E. coli or faecal coliform bacteria. This shift in concentrations is quite prominent in samples with values of either E. coli or faecal coliforms below $10^{2}-10^{3} \mathrm{CFU} / 100 \mathrm{~mL}$ (Contreras-Coll et al., 2002; Ibarluzea et al., 2007; Lucena et al., 2003; Skraber et al., 2002). This is probably due to the greater persistence of phages. The potential application of coliphages in quality control of bathing and recreational surface waters is currently being studied by USA regulatory authorities (U.S. EPA, 2015), though at present, neither concentrations nor which coliphages should be considered have been defined.

\subsubsection{Indicators for the efficiency of reclamation processes and the quality of reclaimed water}

Many of the tertiary treatment processes applied for water reclamation have as the major aim the removal and inactivation of pathogens. The most frequently used processes include filtration and disinfection by chemicals or UV radiation or a combination. The tertiary effluents generally contain substantially reduced numbers of pathogens and indicators, but the proportions between different indicators found in raw wastewater and secondary effluents changed after treatment.

A substantial amount of information is available on the removal of somatic coliphages and F-specific coliphages by tertiary treatment processes and on the numbers of surviving phages in treated effluents (Costán-Longares et al., 2008; den Blanken, 1985; Gomila et al., 2008; Luther and Fujioka, 2004; Mandilara et al., 2006; Montemayor et al., 2008; Nieuwstad et al., 1988; Rose et al., 2004; Rubiano et al., 2012; Soriano et al., 2011; Stiegel et al., 2013; Zhang and Farahbakhsh, 2007).

Removal of both groups of phages varies for different treatment processes and counts of surviving phages may range between 0.5 and $>4.0 \log _{10}$ units. Typically counts of somatic and F-specific coliphages in many tertiary effluents 
(reclaimed waters) are higher than those of faecal indicator bacteria, or at least, the difference is much smaller than in secondary effluents. According to the only available report on Bacteroides phages, their behaviour is similar to that of coliphages.

Because of these kinds of results indicating that the resistance of phages to many treatment processes (see chapters on sanitation and disinfection)resembles that of viruses, coliphages have been included in some regulations regarding water reclamation. Among these are the states of Queensland, Australia (Queensland Government, 2005) and North Carolina, USA (North Carolina Administration, 2011). Both regulations specify a given reduction in numbers of coliphages by the treatment processes concerned as well as the maximum number of coliphages permitted in the reclaimed water.

\subsubsection{Quality indicators of groundwater}

The presence of indicator phages in groundwater has very frequently been reported as presence in 1 litre after concentration and in most studies the results are reported as presence/absence (Abbaszadegan et al., 2003; Borchardt et al., 2004; Jung et al., 2011; Locas et al., 2007; Lucena et al., 2006).

In summary, somatic coliphages were detected in $8.7 \%$ (Payment and Locas, 2011) to 22.4\% (Lucena et al., 2006) of groundwater samples, and F-specific phages in $1 \%$ (Borchardt et al., 2004) to $18.3 \%$ of samples (Lucena et al., 2006).The only study including phages of Bacteroides reports 1.7\% (Lucena et al., 2006). Thus again somatic coliphages are the most abundant ones, followed by Fspecific coliphages and Bacteroides phages. In two of these studies, partial data on aquifers with no faecal contamination and aquifers heavily contaminated are reported, and the values of positive isolations of phages clearly match with the expected contamination. Thus, for somatic coliphages values range from $0 \%$ to $62 \%$ (Lucena et al., 2006) and from $0 \%$ to $25 \%$ (Locas et al., 2007).

In an analysis of $100 \mathrm{~mL}$ groundwater samples, Lucena et al. (2006) reported the presence of E. coli in 18.8\%, somatic coliphages in $22.4 \%$ and F-specific RNA phages in $18.1 \%$ of samples, and in a similar analysis Lee et al. (2011)reported the same indicators to be present in 15\%, $12 \%$ and $7.5 \%$ of samples.

The USEPA rule on groundwater considers coliphages as alternative indicators for quality assessment of groundwater (U.S. EPA, 2006)

\subsubsection{Quality indicators of drinking water}

This refers to disinfected water only. Since indicator phages are more resistant to treatment processes than bacterial indicators (except spores of Clostridium) it can be expected that coliphages and Bacteroides phages are detected in samples of drinking water treated to eliminate the bacterial faecal indicators. This was confirmed by the detection of coliphages in a meaningful percentage of drinking water samples with free residual chlorine and no, or very low, numbers of bacterial indicators in Canada, Egypt and Peru(El-Abagy et al., 1988; Palmateer et al., 1990; Ratto et al., 1989). Méndez et al. (2004a)detected neither $E$ coli nor faecal coliforms in 427 samples of 100 $\mathrm{mL}$ of a metropolitan water network containing $>0.1 \mathrm{mg} / \mathrm{L}$ of chlorine, but detected somatic coliphages, F-specific RNA phages and Bacteroides phages in 8.8, 10 and $4.5 \%$ of $1000 \mathrm{~mL}$ samples, respectively. Likewise, Armon et al. (1997) detected faecal coliforms, somatic coliphages, Fspecific coliphages and Bacteroides phages in 0.7, 5.6, 7.1 and $5 \%$, respectively, of $1536100 \mathrm{~mL}$-samples of disinfected water in Israel. Therefore, coliphages arise as attractive indicators for disinfected drinking water that will provide some more protection than the traditional bacterial indicators. We are not aware of any drinking water quality regulation that considers phages as indicators.

\subsubsection{Quality indicators for treated sludge}

In many countries, regulations require the treatment of sludge for certain destinations as for example in agriculture. As seen in a previous section, coliphages are quite abundant in untreated sludge. The most frequent treatments of sludge are thermophilic digestions, pasteurization, lime stabilization and composting. Anaerobic mesophilic digestion shows a poor hygienization of all the indicators including phages, with values of somatic coliphages as high as $4.4 \times 10^{6} \mathrm{PFUs} / \mathrm{gram}$ (dry weight) of digested sludge (Guzmán et al., 2007). Thermophilic digestions, pasteurization and composting achieving very significant reductions in the number of bacterial indicators showed in-between reductions of $\mathrm{F}$ specific RNA and very moderate reduction in the numbers of somatic coliphages (Astals et al., 2012; Guzmán et al., 2007). Also, storage in quick lime is much more efficient in reducing the numbers of faecal coliforms than those of somatic coliphages (Campos et al., 2002).

Therefore, phage indicators, particularly somatic coliphages, seem to be a serious candidate to be considered as an indicator of hygienization in sludge management. Western Australia (Western Australian Government, 2012) and Colombia (Republica de Colombia, 2014) have introduced coliphages in the regulations about the quality of biosolids (treated sludge) to be applied in agriculture.

\subsection{Other Potential Uses}

In order not to unreasonably enlarge this section it is only mentioned that among other applications related to water quality, phages are also considered as potential indicators for the microbiological quality of shellfish, as well as markers for the transport of microorganisms in soil, and to validate filters.

\subsubsection{Indicators for microbial source tracking}

Among the subgroups of F-specific RNA phages, subgroup I seems to predominate in surface waters. This is difficult to interpret because subgroup I also appear to be the most persistent. In contrast, the few existing data (Ebdon et al., 2007; Muniesa et al., 2012)seem to indicate 
that phages infecting Bacteroides and their ratio to somatic coliphages seem a good option for MST of surface waters where E. coli concentrations are equal to or greater than $10^{3} \mathrm{CFUs} / 100 \mathrm{~mL}$.

Lee et al. (2011) found that $85 \%$ of 60 F-RNA phages isolated from groundwater being subgroup I. No sound data about phages infecting strains GA17 and GB124 in groundwater are available in order to evaluate their potential use for MST in groundwater.

Information on the presence and values of coliphages in solid matrixes is relatively abundant, mostly in untreated and treated sludge, in contrast it is scarce about phages infecting Bacteroides and non-existing for F-specific RNA phage subgroups. The few data available seem to indicate that the ratio between the numbers of somatic coliphages and phages infecting Bacteroides will remain in these matrixes similar to the ratio in sewage (Guzmán et al., 2007; Lasobras et al., 1999; Yahya et al., 2015).

5.2.2 Target enumeration to infer the occurrence of intestinal pathogens

Additionally to their worth as indicators of faecal contamination the indicator phages have been viewed as potential surrogates of human viruses. Consequently, the possible relationship between presence and levels of indicator phages and human viruses in waters has been studied, though with disparate results. However, these studies are quite varied with respect to the assessed parameters and the methods used. Phages have usually been evaluated by plaque assay by standardized (or equivalent methods) in small volumes, and without a concentration procedure. Human viruses have been evaluated after concentration of great volumes and posterior detection with very different methods, such as plaque assay on cell culture and different PCR approaches. Most of these counts, mostly in matrixes where the numbers of phages and viruses are low and mostly those of viruses have a great amount of uncertainty that can explain part of the heterogeneity of the results.

Some studies have failed to show any relationship in fresh surface waters (Hot et al., 2003; Jiang et al., 2007; Viau et al., 2011; Westrell et al., 2006), marine surface water (Boehm et al., 2009; Jiang et al., 2007) and groundwater (Abbaszadegan et al., 2003; Borchardt et al., 2004; Payment and Locas, 2011).

Others have found relationships between human viruses and phage. Jiang et al. (2001) found that the presence of human adenovirus detected by nested-PCR was significantly associated with F-specific coliphages in marine surface waters impacted by urban run-off.

Ballester et al. (2005) described that the presence of astroviruses and adenoviruses was significantly associated with the presence of both somatic and F-specific coliphages in coastal water impacted by WWTP. The presence of rotavirus and enterovirus was only linked to the presence of F-specific phages. Human viruses were detected by ICCnPCR and ICC-RT-nPCR.
Love et al. (2014) described that the presence of $\mathrm{F}$ specific coliphages was associated with the presence of genome copies of adenoviruses but not noroviruses in coastal waters.

Rezaeinejad et al (2014) found that in urbanized catchments of fresh water in tropical Singapore F-specific PFU numbers were associated to counts of genome copies of noroviruses but not with GC of adenoviruses, astroviruses and rotaviruses.

Mocé-Llivina et al. (2005) described a significant association between the presence of enteroviruses enumerated on cell culture and somatic coliphages in marine waters.

Skraber et al. (2004) revealed that in a French river the numbers of samples positive for infectious enterovirus as well as genome copies of enteroviruses and of noroviruses increased with increasing densities of somatic coliphages.

Even if results are far away from indicating a clear correlation between densities of indicator coliphages and human viruses in waters, there is evidence that somatic and F-specific coliphages are more strongly associated with pathogenic viruses that the traditional bacterial indicators.

\subsubsection{Relation to risk}

Several epidemiological studies conducted to evaluate the relationships between the presence of indicator phages in surface waters and swimming illnesses have been performed with disparate outcomes. However, overall the epidemiological evidence suggests a likely relationship between coliphages and human health.

Von Schirnding et al. (1992) conducted a prospective cohort study at 2 South African marine beaches.The numbers of coliphages detected were fairly low and no statistically significant relation was found between sickness and numbers of somatic coliphages.

In studies at freshwater lakes in Germany, Wiedenmann et al. (2006) found a significantly increased risk of gastroenteritis for persons bathing in water with concentrations of somatic coliphages greater than 10 PFU/100 mL versus non-bathing fellows.

In an epidemiological study to evaluate water quality and health effects for waters at a marine beach in Florida (Abdelzaher et al., 2011), the detection of somatic coliphages overlapped with the highest illness days. However, no significant correlation between health outcomes and somatic coliphages was observed.

Lee et al. (1997) found in Great Britain a statistically significant association between risk of gastrointestinal illness and density of F-specific RNA coliphages.

Van Asperen et al. (1998) did not find exposureresponse association between F-specific RNA phages and gastrointestinal illness in a study performed in Holland.

In a study on swimmers at marine beaches in 
California,Colford et al. (2007)found skin rash and diarrhoea, but no other health symptoms, to correlate with the presence of F-specific phages but not with that of somatic coliphages.

In a comparison of swimmers to non-swimmers at marine beaches in Alabama, Mississippi, and Rhode Island, a significantly higher risk of gastrointestinal illness has been reported for days when coliphages were present (Wade et al., 2010). No epidemiological studies seem to be on record regarding a correlation of phages in drinking water to related disease.
An overlapping between a jaundice outbreak and a high incidence of somatic coliphages in potable water occurred in a municipality of West Bengala, India in 2014. Somatic coliphages ranging from 40 to $250 \mathrm{PFU} / 100 \mathrm{~mL}$ were detected in 16 out of 20 samples during the outbreak detected in December 2013, whereas E. coli was detected in only 2 of the samples. A few weeks after the outbreak, somatic coliphages were only detected in four out of twenty samples with positive values ranging from 10 to 50 $\mathrm{PFU} / 100 \mathrm{~mL}$, and E. coli in none (Mookerjee et al., 2014). 


\section{References}

Abbaszadegan, M., LeChevallier, M. and Gerba, C. (2003). Occurrence of Viruses in US Groundwaters (PDF). Journal American Water Works Association. 95, pp. 107-120.

Abdelzaher, A.M., Wright, M.E., Ortega, C., A Hasan, R., Shibata, T., Solo-Gabriele, H.M. et al. (2011). Daily measures of microbes and human health at a non-point source marine beach. Journal of Water and Health. 9, pp. 443-57. doi: 10.2166/wh.2011.146.

Adams, M.H. (1959). Bacteriophages. Bacteriophages. New York, NY pp. 592.

Agulló-Barceló, M., Polo-López, M.I., Lucena, F., Jofre, J. and Fernandez-Ibanez, P. (2013). Solar Advanced Oxidation Processes as disinfection tertiary treatments for real wastewater: Implications for water reclamation. Applied Catalysis B: Environmental. 136-137, pp. 341-350. doi: 10.1016/j.apcatb.2013.01.069.

Alcalde, L., Oron, G., Gillerman, L., Salgot, M. and Manor, Y. (2003). Removal of fecal coliforms, somatic coliphages and Fspecific bacteriophages in a stabilization pond and reservoir system in arid regions. Water Science and Technology: Water Supply. 3, pp. 177-184.

Araujo, R., Muniesa, M., Méndez, J., Puig, A., Queralt, N., Lucena, F. et al. (2001). Optimisation and standardisation of a method for detecting and enumerating bacteriophages infecting Bacteroides fragilis. Journal of Virological Methods. 93, pp. 127-36.

Armon, R., Araujo, R., Kott, Y., Lucena, F. and Jofre, J. (1997). Bacteriophages of enteric bacteria in drinking water, comparison of their distribution in two countries. Journal of Applied Microbiology. 83, pp. 627-33.

Armon, R. and Kott, Y. (1996). Bacteriophages as indicators of pollution. Critical Reviews in Environmental Science and Technology. 26, pp. 299-335. doi: 10.1080/10643389609388494.

Astals, S., Venegas, C., Peces, M., Jofre, J., Lucena, F. and Mata-Alvarez, J. (2012). Balancing hygienization and anaerobic digestion of raw sewage sludge. Water Research. 46, pp. 6218-27. doi: 10.1016/j.watres.2012.07.035.

Ballester, N.A., Fontaine, J.H. and Margolin, A.B. (2005). Occurrence and correlations between coliphages and anthropogenic viruses in the Massachusetts Bay using enrichment and ICC-nPCR. Journal of Water and Health. 3, pp. 59-68.

Beekwilder, J., Nieuwenhuizen, R., Havelaar, A.H. and van Duin, J. (1996). An oligonucleotide hybridization assay for the identification and enumeration of F-specific RNA phages in surface water. The Journal of Applied Bacteriology. 80, pp. 179-86.

Blanch, A.R., Belanche-Muñoz, L., Bonjoch, X., Ebdon, J., Gantzer, C., Lucena, F. et al. (2006). Integrated analysis of established and novel microbial and chemical methods for microbial source tracking. Applied and Environmental Microbiology. 72, pp. 5915-26. doi: 10.1128/AEM.02453-05.

Blanken, J.G. den (1985). Comparative disinfection of treated sewage with chlorine and ozone. Water Research. 19, pp. 1129-1140. doi: 10.1016/0043-1354(85)90349-5.

Boehm, A.B., Yamahara, K.M., Love, D.C., Peterson, B.M., McNeill, K. and Nelson, K.L. (2009). Covariation and photoinactivation of traditional and novel indicator organisms and human viruses at a sewage-impacted marine beach. Environmental Science and Technology. 43, pp. 8046-52. doi: 10.1021/es9015124.

Borchardt, M.A., Haas, N.L. and Hunt, R.J. (2004). Vulnerability of drinking-water wells in La Crosse, Wisconsin, to entericvirus contamination from surface water contributions. Applied and Environmental Microbiology. 70, pp. 5937-46. doi: 10.1128/AEM.70.10.5937-5946.2004.

Brion, G.M., Meschke, J.S. and Sobsey, M.D. (2002). F-specific RNA coliphages: occurrence, types, and survival in natural waters. Water Research. 36, pp. 2419-25. 
Burbano-Rosero, E.M., Ueda-Ito, M., Kisielius, J.J., Nagasse-Sugahara, T.K., Almeida, B.C., Souza, C.P. et al. (2011). Diversity of somatic coliphages in coastal regions with different levels of anthropogenic activity in São Paulo State, Brazil. Applied and Environmental Microbiology. 77, pp. 4208-16. doi: 10.1128/AEM.02780-10.

Calci, K.R., Burkhardt, W., Watkins, W.D. and Rippey, S.R. (1998). Occurrence of male-specific bacteriophage in feral and domestic animal wastes, human feces, and human-associated wastewaters. Applied and Environmental Microbiology. 64, pp. 5027-9.

Campos, C., Guerrero, A. and Cárdenas, M. (2002). Removal of bacterial and viral faecal indicator organisms in a waste stabilization pond system in Choconta, Cundinamarca (Colombia). Water Science and Technology : a journal of the International Association on Water Pollution Research. 45, pp. 61-6.

Campos, C., Beltrán, M., Duarte, M., Medina, L., Lucena, F. and Jofre, J. (2013). Abatement of Helminth Eggs and Bacterial and Viral Indicators in Soil after Land Application of Treated Sludges. Journal of Water Resource and Protection. 05, pp. 1155-1164. doi: 10.4236/jwarp.2013.512122.

Chauret, C., Springthorpe, S. and Sattar, S. (1999). Fate of Cryptosporidium oocysts, Giardia cysts, and microbial indicators during wastewater treatment and anaerobic sludge digestion. Canadian Journal of Microbiology. 45, pp. 257-62.

Chung, H., Jaykus, L.A. and Sobsey, M.D. (1996). Detection of human enteric viruses in oysters by in vivo and in vitro amplification of nucleic acids. Applied and Environmental Microbiology. 62, pp. 3772-8.

Cole, D., Long, S.C. and Sobsey, M.D. (2003). Evaluation of F+ RNA and DNA coliphages as source-specific indicators of fecal contamination in surface waters. Applied and Environmental Microbiology. 69, pp. 6507-14.

Colford, J.M., Wade, T.J., Schiff, K.C., Wright, C.C., Griffith, J.F., Sandhu, S.K. et al. (2007). Water quality indicators and the risk of illness at beaches with nonpoint sources of fecal contamination. Epidemiology (Cambridge, Mass.). 18, pp. 27-35. doi: 10.1097/01.ede.0000249425.32990.b9.

Colomer-Lluch, M., Imamovic, L., Jofre, J. and Muniesa, M. (2011). Bacteriophages carrying antibiotic resistance genes in fecal waste from cattle, pigs, and poultry. Antimicrobial Agents and Chemotherapy. 55, pp. 4908-4911. doi: 10.1128/AAC.00535-11.

Contreras-Coll, N., Lucena, F., Mooijman, K., Havelaar, A., Pierz, V., Boque, M. et al. (2002). Occurrence and levels of indicator bacteriophages in bathing waters throughout Europe. Water Research. 36, pp. 4963-74.

Cooper, S.W., Szymczak, E.G., Jacobus, N.V. and Tally, F.P. (1984). Differentiation of Bacteroides ovatus and Bacteroides thetaiotaomicron by means of bacteriophage. Journal of Clinical Microbiology. 20, pp. 1122-5.

Cornax, R., Moriñigo, M.A., Balebona, M.C., Castro, D. and Borrego, J.J. (1991). Significance of several bacteriophage groups as indicators of sewage pollution in marine waters. Water Research. 25, pp. 673-678. doi: 10.1016/0043-1354(91)90042-O.

Costán-Longares, A., Montemayor, M., Payán, A., Méndez, J., Jofre, J., Mujeriego, R. et al. (2008). Microbial indicators and pathogens: removal, relationships and predictive capabilities in water reclamation facilities. Water Research. 42 , pp. 4439-4448. doi: 10.1016/j.watres.2008.07.037.

Debartolomeis, J. and Cabelli, V.J. (1991). Evaluation of an Escherichia coli host strain for enumeration of F male-specific bacteriophages. Applied and Environmental Microbiology. 57, pp. 1301-5.

DeBorde, D.C., Woessner, W.W., Lauerman, B. and Ball, P. (1998). Coliphage prevalence in high school septic effluent and associated ground water. Water Research. 32, pp. 3781-3785. doi: 10.1016/S0043-1354(98)00171-7.

Diston, D. and Wicki, M. (2015). Occurrence of bacteriophages infecting Bacteroides host strains (ARABA 84 and GB-124) in fecal samples of human and animal origin. Journal of Water and Health. 13, pp. 654-61. doi: 10.2166/wh.2014.199.

Donnison, A.M. and Ross, C.M. (1995). Somatic and F-specific coliphages in New Zealand waste treatment lagoons. Water Research. 29, pp. 1105-1110. doi: 10.1016/0043-1354(94)00227-X. 
Durán, A.E., Muniesa, M., Méndez, X., Valero, F., Lucena, F. and Jofre, J. (2002). Removal and inactivation of indicator bacteriophages in fresh waters. Journal of Applied Microbiology. 92, pp. 338-47.

Ebdon, J., Muniesa, M. and Taylor, H. (2007). The application of a recently isolated strain of Bacteroides (GB-124) to identify human sources of faecal pollution in a temperate river catchment. Water Research. 41, pp. 3683-3690.

El-Abagy, M.M., Dutka, B.J., Kamel, M. and Zanfaly, H.T. el (1988). Incidence of coliphage in potable water supplies. Applied and Environmental Microbiology. 54, pp. 1632-3.

EPA, U.S. (2015). Review of coliphages as possible indicators of fecal contamination for ambient water quality. EPA 820R-15-098. Washington D.C.

EPA, U.S. (2006). National Primary Drinking Water Regulations: Groundwater rule. Final Rule; 40 CFR Parts 9 , 141 and 142. Federal register, vol. 71. Washington D.C.

EPA, U.S. (2003). Results of the Interlaboratory Validation of EPA Method 1601 for Presence/Absence of Male specific (F+) and Somatic Coliphages in Water by Two-Step Enrichment. EPA 821-R-03-015. Washington D.C.

EPA, U.S. (2003). Results of the Interlaboratory Validation of EPA Method 1602 for Enumeration of Male specific (F+) and Somatic Coliphage in Water by Single Agar Layer (SAL). EPA 821-R-03-016. Washington D.C.

EPA, U.S. (2001). Method 1602: Male-specific (F+) and Somatic Coliphage in Water by Single Agar Layer (SAL) Procedure. EPA 821-R-01-029. Washington D.C.

EPA, U.S. (2001). Method 1601: Detection of Male-specific (F+) and Somatic Coliphage in Water by Two-Step Enrichment Procedure. EPA 821-R-01-030. Washington D.C.

EPA, U.S. (2001). USEPA Manual of Methods for Virology. Chapter 16. EPA 600/4-84/013 (N16). Washington D.C.

Fauquet, C.M. and Fargette, D. (2005). International Committee on Taxonomy of Viruses and the 3,142 unassigned species. Virology Journal. 2, pp. 64. doi: 10.1186/1743-422X-2-64.

Friedman, S.D., Cooper, E.M., Casanova, L., Sobsey, M.D. and Genthner, F.J. (2009). A reverse transcription-PCR assay to distinguish the four genogroups of male-specific (F+) RNA coliphages. Journal of Virological Methods. 159, pp. 47-52. doi: 10.1016/j.jviromet.2009.02.028.

Fu, C.Y., Xie, X., Huang, J.J., Zhang, T., Wu, Q.Y., Chen, J.N. et al. (2010). Monitoring and evaluation of removal of pathogens at municipal wastewater treatment plants. Water science and technology : a journal of the International Association on Water Pollution Research. 61, pp. 1589-99. doi: 10.2166/wst.2010.757.

Furuse, K. (1987). Distribution of coliphages in the environment: general considerations. Phage Ecology. (Goyal, S.M., Gerba, C.P. and Bitton, G., ed.). New York, NY, USA pp. 87-123.

Gómez-Doñate, M., Payán, A., Cortés, I., Blanch, A.R., Lucena, F., Jofre, J. et al. (2011). Isolation of bacteriophage host strains of Bacteroides species suitable for tracking sources of animal faecal pollution in water. Environmental Microbiology. 13, pp. 1622-31. doi: 10.1111/j.1462-2920.2011.02474.x.

Gantzer, C., Henny, J. and Schwartzbrod, L. (2002). Bacteroides fragilis and Escherichia coli bacteriophages in human faeces. International Journal of Hygiene and Environmental Health. 205, pp. 325-8. doi: 10.1078/1438-4639-00152.

García-Aljaro, C., Muniesa, M., Jofre, J., Blanch, A.R., García-Aljaro, C., Muniesa, M. et al. (2004). Prevalence of the stx2 gene in coliform populations from aquatic environments. Applied and Environmental Microbiology. 2004/06/09 ed.70, pp. 3535-3540. doi: 10.1128/AEM.70.6.3535-3540.200470/6/3535 [pii].

Gomila, M., Solis, J.J., David, Z., Ramon, C. and Lalucat, J. (2008). Comparative reductions of bacterial indicators, bacteriophage-infecting enteric bacteria and enteroviruses in wastewater tertiary treatments by lagooning and UVradiation. Water Science and Technology : a journal of the International Association on Water Pollution Research. 58, pp. 2223-33. doi: 10.2166/wst.2008.584. 
Grabow, W., Neubrech, T.E. and (1995). Bacteroides fragilis and Escherichia coli bacteriophages: excretion by humans and animals. Water Science and Technology. 31, pp. 223-230. doi: 10.1016/0273-1223(95)00270-W.

Grabow, WOK. (2001). Bacteriophages: update on application as models for viruses in water. Water SA. 27, pp. 251-268. doi: 10.4314/wsa.v27i2.4999.

Grabow, WOK., Holtzhausen, CS. and De Villiers, JC. (1993). Research on bacteriophages as indicators of water quality. Water Research Commission report.

Green, J. (2000). The APHA standard method for the enumeration of somatic coliphages in water has low efficiency of plating. Water Research. 34, pp. 759-762. doi: 10.1016/S0043-1354(99)00233-X.

Guzmán, C., Jofre, J., Montemayor, M. and Lucena, F. (2007). Occurrence and levels of indicators and selected pathogens in different sludges and biosolids. Journal of Applied Microbiology. 103, pp. 2420-9. doi: 10.1111/j.1365-2672.2007.03487.x.

Guzmán, C., Mocé-Llivina, L., Lucena, F. and Jofre, J. (2008). Evaluation of Escherichia coli host strain CB390 for simultaneous detection of somatic and F-specific coliphages. Applied and Environmental Microbiology. 74, pp. 531-4. doi: 10.1128/AEM.01710-07.

Haramoto, E., Fujino, S. and Otagiri, M. (2015). Distinct behaviors of infectious F-specific RNA coliphage genogroups at a wastewater treatment plant. The Science of the Total Environment. 520, pp. 32-8. doi: 10.1016/j.scitotenv.2015.03.034.

Haramoto, E., Katayama, H., Oguma, K. and Ohgaki, S. (2005). Application of cation-coated filter method to detection of noroviruses, enteroviruses, adenoviruses, and torque teno viruses in the Tamagawa River in Japan. Applied and Environmental Microbiology. 71, pp. 2403-11. doi: 10.1128/AEM.71.5.2403-2411.2005.

Hartard, C., Rivet, R., Banas, S. and Gantzer, C. (2015). Occurrence of and Sequence Variation among F-Specific RNA Bacteriophage Subgroups in Feces and Wastewater of Urban and Animal Origins. Applied and Environmental Microbiology. 81, pp. 6505-15. doi: 10.1128/AEM.01905-15.

Hata, A., Kitajima, M. and Katayama, H. (2013). Occurrence and reduction of human viruses, F-specific RNA coliphage genogroups and microbial indicators at a full-scale wastewater treatment plant in Japan. Journal of Applied Microbiology. 114, pp. 545-54. doi: 10.1111/jam.12051.

Havelaar, A.H., Furuse, K. and Hogeboom, W.M. (1986). Bacteriophages and indicator bacteria in human and animal faeces. The Journal of Applied Bacteriology. 60, pp. 255-62.

Havelaar, A.H. and Hogeboom, W.M. (1984). A method for the enumeration of male-specific bacteriophages in sewage. The Journal of Applied Bacteriology. 56, pp. 439-47.

Havelaar, A.H. and Hogeboom, W.M. (1983). Factors affecting the enumeration of coliphages in sewage and sewagepolluted waters. Antonie van Leeuwenhoek. 49, pp. 387-97.

Havelaar, A.H., Pot-Hogeboom, W.M., Furuse, K., Pot, R. and Hormann, M.P. (1990). F-specific RNA bacteriophages and sensitive host strains in faeces and wastewater of human and animal origin. The Journal of Applied Bacteriology. 69, pp. $30-7$.

Havelaar, A.H. and Pot-Hogeboom, W.M. (1988). F-Specific RNA-Bacteriophages as Model Viruses in Water Hygiene: Ecological Aspects. Water Science and Technology. 20, pp. 399-407.

Hawkins, S.A., Layton, A.C., Ripp, S., Williams, D. and Sayler, G.S. (2008). Genome sequence of the Bacteroides fragilis phage ATCC 51477-B1. Virology Journal. 5, pp. 97. doi: 10.1186/1743-422X-5-97.

Hernández-Delgado, E. and Toranzos, G. (1995). In situ replication studies of somatic and male-specific coliphages in a tropical pristine river. Water Science and Technology. 31, pp. 247-250. doi: 10.1016/0273-1223(95)00274-Q.

Hill, V. and Sobsey, M. (1998). Microbial indicator reductions in alternative treatment systems for swine wastewater. 
Water Science and Technology. 38, pp. 119-122. doi: 10.1016/S0273-1223(98)00811-7.

Hot, D., Legeay, O., Jacques, J., Gantzer, C., Caudrelier, Y., Guyard, K. et al. (2003). Detection of somatic phages, infectious enteroviruses and enterovirus genomes as indicators of human enteric viral pollution in surface water. Water Research. 37, pp. 4703-4710.

Hsu, F.C., Shieh, Y.S., van Duin, J., Beekwilder, M.J. and Sobsey, M.D. (1995). Genotyping male-specific RNA coliphages by hybridization with oligonucleotide probes. Applied and Environmental Microbiology. 61, pp. 3960-6.

IAWPRC Study group on health related water microbiology (1991). Bacteriophages as model viruses in water quality controlag. Water Research. 25(5), pp. 529-545. doi: 10.1016/0043-1354(91)90126-B.

Ibarluzea, J.M., Marina, L.Santa, Moreno, B., Serrano, E., Larburu, K., Maiztegi, M.J. et al. (2007). Somatic coliphages and bacterial indicators of bathing water quality in the beaches of Gipuzkoa, Spain. Journal of Water and Health. 5, pp. 417-26. doi: 10.2166/wh.2007.037.

ISO (2001). ISO 10705-4: Water quality. Detection and enumeration of bacteriophages -part 4: Enumeration of bacteriophages infecting Bacteroides fragilis. Geneva. Switzerland.

ISO (2000). ISO 10705-2: Water quality. Detection and enumeration of bacteriophages -part 2: Enumeration of somatic coliphages. Geneva.

ISO (1995). ISO 10705-1. Water Quality - Detection and enumeration of bacteriophages - Part 1: Enumeration of F-specific RNA Bacteriophages. International Standardisation Organisation. Geneva, Switzerland.

Jiang, S., Noble, R. and Chu, W. (2001). Human adenoviruses and coliphages in urban runoff-impacted coastal waters of Southern California. Applied and Environmental Microbiology. 67, pp. 179-84. doi: 10.1128/AEM.67.1.179-184.2001.

Jiang, S.C., Chu, W. and He, J-W. (2007). Seasonal detection of human viruses and coliphage in Newport Bay, California. Applied and Environmental Microbiology. 73, pp. 6468-74. doi: 10.1128/AEM.01370-07.

Jofre, J. (2009). Is the replication of somatic coliphages in water environments significant?. Journal of Applied Microbiology. 106, pp. 1059-69. doi: 10.1111/j.1365-2672.2008.03957.x.

Jofre, J., Stewart, JR. and Grabow, W. (2011). Phage Methods. Microbial Source Tracking: Methods, Applications, and Case Studies. (Hagedorn, C., Blanch, AR. and Harwood, VJ., ed.). New York, NY pp. 137-156.

Jofre, J., Blanch, A.R., Lucena, F. and Muniesa, M. (2014). Bacteriophages infecting Bacteroides as a marker for microbial source tracking. Water Research. 55, pp. 1-11. doi: 10.1016/j.watres.2014.02.006.

Jofre, J. (2007). Human Viruses in Water. Perspectives in Medical Virology. 17, pp. 227-249. doi: 10.1016/S0168-7069(07)17011-7.

Jones, T.H. and Johns, M.W. (2009). Improved detection of F-specific RNA coliphages in fecal material by extraction and polyethylene glycol precipitation. Applied and Environmental Microbiology. 75, pp. 6142-6. doi: 10.1128/AEM.00436-09.

Jung, J.Hee, Yoo, C.Hoon, Koo, E.Seo, Kim, H.Min, Na, Y., Jheong, W.Hwa et al. (2011). Occurrence of norovirus and other enteric viruses in untreated groundwaters of Korea. Journal of Water and Health. 9, pp. 544-55. doi: 10.2166/wh.2011.142.

Kator, H. and Rhodes, M. (1992). Evaluation of Bacteroides fragilis Bacteriophages, a Candidate Human-specific Indicator of Faecal Contamination from Shellfish Growing Waters. Final Report. Gloucester Point, Virginia, USA.

Kirs, M. and Smith, D.C. (2007). Multiplex quantitative real-time reverse transcriptase PCR for F+-specific RNA coliphages: a method for use in microbial source tracking. Applied and Environmental Microbiology. 73, pp. 808-14. doi: 10.1128/AEM.00399-06.

Kory, M.M. and S. Booth, J. (1986). Characteristics of Bacteroides fragilis bacteriophages and comparison of their DNAs. Current Microbiology. 14, pp. 199-203. doi: 10.1007/BF01568518. 
Kott, Y., Roze, N., Sperber, S. and Betzer, N. (1974). Bacteriophages as viral pollution indicators. Water Research. 8, pp. 165-171. doi: 10.1016/0043-1354(74)90039-6.

Lasobras, J., Dellunde, J., Jofre, J. and Lucena, F. (1999). Occurrence and levels of phages proposed as surrogate indicators of enteric viruses in different types of sludges. Journal of Applied Microbiology. 86, pp. 723-9.

Lee, J.V., Dawson, S.R., Ward, S., Surman, S.B. and Neal, K.R. (1997). Bacteriophages are a better indicator of illness rates than bacteria amongst users of a white water course fed by a lowland river. Water Science and Technology. 35, pp. 165-170.

Lee, J.Eun, Lee, H., Cho, Y-H., Hur, H-G. and Ko, G. (2011). F+ RNA coliphage-based microbial source tracking in water resources of South Korea. The Science of the Total Environment. 412-413, pp. 127-31. doi: 10.1016/j.scitotenv.2011.09.061.

Lee, J.Eun, Lim, M.Young, Kim, S.Yoon, Lee, S., Lee, H., Oh, H-M. et al. (2009). Molecular characterization of bacteriophages for microbial source tracking in Korea. Applied and Environmental Microbiology. 75, pp. 7107-14. doi: 10.1128/AEM.00464-09.

Letarov, A. and Kulikov, E. (2009). The bacteriophages in human- and animal body-associated microbial communities. Journal of Applied Microbiology. 107, pp. 1-13. doi: 10.1111/j.1365-2672.2009.04143.x.

Locas, A., Barthe, C., Barbeau, B., Carrière, A. and Payment, P. (2007). Virus occurrence in municipal groundwater sources in Quebec, Canada. Canadian Journal of Microbiology. 53, pp. 688-94. doi: 10.1139/W07-034.

Lodder, W.J. and De Roda Husman, A.M. (2005). Presence of noroviruses and other enteric viruses in sewage and surface waters in The Netherlands. Applied and Environmental Microbiology. 71, pp. 1453-61. doi: 10.1128/AEM.71.3.1453-1461.2005.

Long, S.C., El-Khoury, S.S., Oudejans, S.J.G., Sobsey, M.D. and Vinjé, J. (2005). Assessment of Sources and Diversity of Male-Specific Coliphages for Source Tracking. Environmental Engineering Science. 22, pp. 367-377. doi: 10.1089/ees.2005.22.367.

Love, D.C., Rodriguez, R.A., Gibbons, C.D., Griffith, J.F., Yu, Q., Stewart, J.R. et al. (2014). Human viruses and viral indicators in marine water at two recreational beaches in Southern California, USA. Journal of Water and Health. 12, pp. 136-50. doi: 10.2166/wh.2013.078.

Love, D.C. and Sobsey, M.D. (2007). Simple and rapid F+ coliphage culture, latex agglutination, and typing assay to detect and source track fecal contamination. Applied and Environmental Microbiology. 73, pp. 4110-8. doi: 10.1128/AEM.02546-06.

Lucena, F., Durán, A.E., Morón, A., Calderón, E., Campos, C., Gantzer, C. et al. (2004). Reduction of bacterial indicators and bacteriophages infecting faecal bacteria in primary and secondary wastewater treatments. Journal of Applied Microbiology. 97, pp. 1069-76. doi: 10.1111/j.1365-2672.2004.02397.x.

Lucena, F., Méndez, X., Morón, A., Calderón, E., Campos, C., Guerrero, A. et al. (2003). Occurrence and densities of bacteriophages proposed as indicators and bacterial indicators in river waters from Europe and South America. Journal of Applied Microbiology. 94, pp. 808-15.

Lucena, F., Ribas, F., Durán, A.E., Skraber, S., Gantzer, C., Campos, C. et al. (2006). Occurrence of bacterial indicators and bacteriophages infecting enteric bacteria in groundwater in different geographical areas. Journal of Applied Microbiology. 101, pp. 96-102. doi: 10.1111/j.1365-2672.2006.02907.x.

Luther, K. and Fujioka, R. (2004). Usefulness of monitoring tropical streams for male-specific RNA coliphages. Journal of Water and Health. 2, pp. 171-81.

Méndez, J., Jofre, J., Lucena, F., Contreras, N., Mooijman, K. and Araujo, R. (2002). Conservation of phage reference materials and water samples containing bacteriophages of enteric bacteria. Journal of Virological Methods. 106, pp. 215-24.

Méndez, J., Audicana, A., Cancer, M., Isern, A., Llaneza, J., Moreno, B. et al. (2004). Assessment of drinking water quality 
using indicator bacteria and bacteriophages. Journal of Water and Health. 2, pp. 201-14.

Méndez, J., Audicana, A., Isern, A., Llaneza, J., Moreno, B., Tarancón, M.Luisa et al. (2004). Standardised evaluation of the performance of a simple membrane filtration-elution method to concentrate bacteriophages from drinking water. Journal of Virological Methods. 117, pp. 19-25. doi: 10.1016/j.jviromet.2003.11.013.

Mandilara, G.D., Smeti, E.M., Mavridou, A.Th, Lambiri, M.P., Vatopoulos, A.C. and Rigas, F.P. (2006). Correlation between bacterial indicators and bacteriophages in sewage and sludge. FEMS Microbiology Letters. 263, pp. 119-26. doi: 10.1111/j.1574-6968.2006.00414.x.

Martínez-Castillo, A., Quirós, P., Navarro, F., Miró, E. and Muniesa, M. (2013). Shiga toxin 2-encoding bacteriophages in human fecal samples from healthy individuals. Applied and Environmental Microbiology. 79, pp. 4862-8. doi: 10.1128/AEM.01158-13.

McLaughlin, M.R. and Rose, J.B. (2006). Application of Bacteroides fragilis phage as an alternative indicator of sewage pollution in Tampa Bay, Florida. Estuaries and Coasts. 29, pp. 246-256. doi: 10.1007/BF02781993.

McMinn, B.R., Korajkic, A. and Ashbolt, N.J. (2014). Evaluation of Bacteroides fragilis GB-124 bacteriophages as novel human-associated faecal indicators in the United States. Letters in Applied Microbiology. 59, pp. 115-21. doi: 10.1111/lam.12252.

Mocé-Llivina, L., Jofre, J. and Muniesa, M. (2003). Comparison of polyvinylidene fluoride and polyether sulfone membranes in filtering viral suspensions. Journal of Virological Methods. 109, pp. 99-101.

Mocé-Llivina, L., Lucena, F. and Jofre, J. (2005). Enteroviruses and bacteriophages in bathing waters. Applied and Environmental Microbiology. 71, pp. 6838-44. doi: 10.1128/AEM.71.11.6838-6844.2005.

Montemayor, M., Costan, A., Lucena, F., Jofre, J., Muñoz, J., Dalmau, E. et al. (2008). The combined performance of UV light and chlorine during reclaimed water disinfection. Water science and technology : a journal of the International Association on Water Pollution Research. 57, pp. 935-40. doi: 10.2166/wst.2008.206.

Mooijman, K.A., Ghameshlou, Z., Bahar, M., Jofre, J. and Havelaar, A.H. (2005). Enumeration of bacteriophages in water by different laboratories of the European Union in two interlaboratory comparison studies. Journal of Virological Methods. 127, pp. 60-8. doi: 10.1016/j.jviromet.2005.02.013.

Mookerjee, S., Batabyal, P., Halder, M. and Palit, A. (2014). Specificity of coliphages in evaluating marker efficacy: a new insight for water quality indicators. Journal of Virological Methods. 208, pp. 115-8. doi: 10.1016/j.jviromet.2014.07.036.

Muniesa, M., Lucena, F. and Jofre, J. (1999). Study of the potential relationship between the morphology of infectious somatic coliphages and their persistence in the environment. Journal of Applied Microbiology. 87, pp. 402-9.

Muniesa, M., Lucena, F., Blanch, A.R., Payán, A. and Jofre, J. (2012). Use of abundance ratios of somatic coliphages and bacteriophages of Bacteroides thetaiotaomicron GA17 for microbial source identification. Water Research. 46, pp. 6410-8. doi: 10.1016/j.watres.2012.09.015.

Muniesa, M., Mocé-Llivina, L., Katayama, H. and Jofre, J. (2003). Bacterial host strains that support replication of somatic coliphages. Antonie van Leeuwenhoek. 83, pp. 305-315.

Muniesa, M., Payán, A., Mocé-Llivina, L., Blanch, A.R. and Jofre, J. (2009). Differential persistence of F-specific RNA phage subgroups hinders their use as single tracers for faecal source tracking in surface water. Water Research. 43, pp. 1559-64. doi: 10.1016/j.watres.2008.12.038.

Nappier, S.P., Aitken, M.D. and Sobsey, M.D. (2006). Male-specific coliphages as indicators of thermal inactivation of pathogens in biosolids. Applied and Environmental Microbiology. 72, pp. 2471-5. doi: 10.1128/AEM.72.4.2471-2475.2006.

Nieuwstad, T.J., Mulder, E.P., Havelaar, A.H. and Van Olphen, M. (1988). Elimination of micro-organisms from wastewater by tertiary precipitation and simultaneous precipitation followed by filtration. Water Research. 22, pp. 1389-1397. doi: 10.1016/0043-1354(88)90095-4. 
North Carolina Administration (2011). North Carolina Administrative Code 15A NCAC 2U. Raleigh, USA.

O'Connell, K.P., Bucher, J.R., Anderson, P.E., Cao, C.J., Khan, A.S., Gostomski, M.V. et al. (2006). Real-time fluorogenic reverse transcription-PCR assays for detection of bacteriophage MS2. Applied and Environmental Microbiology. 72, pp. 478-83. doi: 10.1128/AEM.72.1.478-483.2006.

Ogilvie, L.A., Bowler, L.D., Caplin, J., Dedi, C., Diston, D., Cheek, E. et al. (2013). Genome signature-based dissection of human gut metagenomes to extract subliminal viral sequences. Nature Communications. 4, pp. 2420. doi: 10.1038/ncomms3420.

Ogorzaly, L. and Gantzer, C. (2006). Development of real-time RT-PCR methods for specific detection of F-specific RNA bacteriophage genogroups: application to urban raw wastewater. Journal of Virological Methods. 138, pp. 131-9. doi: 10.1016/j.jviromet.2006.08.004.

Ogunseitan, O.A., Sayler, G.S. and Miller, R.V. (1990). Dynamic interactions ofPseudomonas aeruginosa and bacteriophages in lake water. Microbial Ecology. 19, pp. 171-85. doi: 10.1007/BF02012098.

Palmateer, G.A., Dutka, B.J., Janzen, E.M., Meissner, S.M. and Sakellaris, M. (1990). Coliphages and bacteriophages in canadian drinking waters. Water International. 15, pp. 157-159. doi: 10.1080/02508069008687132.

Payán, A., Ebdon, J., Taylor, H., Gantzer, C., Ottoson, J., Papageorgiou, G.T. et al. (2005). Method for isolation of Bacteroides bacteriophage host strains suitable for tracking sources of fecal pollution in water. Applied and Environmental Microbiology. 71, pp. 5659-62. doi: 10.1128/AEM.71.9.5659-5662.2005.

Payment, P. and Locas, A. (2011). Pathogens in water: value and limits of correlation with microbial indicators. Ground Water. 49, pp. 4-11. doi: 10.1111/j.1745-6584.2010.00710.x.

Perez-Rodriguez, R., Haitjema, C., Huang, Q., Nam, K.Hyun, Bernardis, S., Ke, A. et al. (2011). Envelope stress is a trigger of CRISPR RNA-mediated DNA silencing in Escherichia coli. Molecular Microbiology. 79, pp. 584-99. doi: 10.1111/j.1365-2958.2010.07482.x.

Puig, A., Araujo, R., Jofre, J. and Frias-Lopez, J. (2001). Identification of cell wall proteins of Bacteroides fragilis to which bacteriophage B40-8 binds specifically. Microbiology (Reading, England). 147, pp. 281-8. doi: 10.1099/00221287-147-2-281.

Puig, A., Queralt, N., Jofre, J. and Araujo, R. (1999). Diversity of bacteroides fragilis strains in their capacity to recover phages from human and animal wastes and from fecally polluted wastewater. Applied and Environmental Microbiology. 65, pp. 1772-6.

Queensland Government (2005). Queensland Water Recycling Guidelines. Brisbane. Australia.

Queralt, N., Jofre, J., Araujo, R. and Muniesa, M. (2003). Homogeneity of the morphological groups of bacteriophages infecting Bacteroides fragilis strain HSP40 and strain RYC2056. Current Microbiology. 46, pp. 163-8. doi: 10.1007/s00284-002-3813-7.

Raivio, T. (2011). Identifying your enemies-could envelope stress trigger microbial immunity?. Molecular Microbiology. 79, pp. 557-61. doi: 10.1111/j.1365-2958.2010.07485.x.

Rajala-Mustonen, R.L. and Heinonen-Tanski, H. (1994). Sensitivity of host strains and host range of coliphages isolated from finnish and nicaraguan wastewater. Water Research. 28, pp. 1811-1815. doi: 10.1016/0043-1354(94)90254-2.

Ratto, A., Dutka, B.J., Vega, C., Lopez, C. and El-Shaarawi, A. (1989). Potable water safety assessed by coliphage and bacterial tests. Water Research. 23, pp. 253-255. doi: 10.1016/0043-1354(89)90050-X.

Republica de Colombia (2014). Decreto no 1287 . Criterios para el uso de biosólidos generados en plantas de tratamiento de aguas residuales municipales. Bogota, Colombia.

Rezaeinejad, S., Vergara, G.G.R.V., Woo, C.H., Lim, T.T., Sobsey, M.D. and Gin, K.Y.H. (2014). Surveillance of enteric 
viruses and coliphages in a tropical urban catchment. Water Research. 58, pp. 122-31. doi: 10.1016/j.watres.2014.03.051.

Rice, E. (2012). Standard methods for the examination of water and wastewater prepared and published jointly by American Public Health Association, American Water Works Association, Water Environment Federation. Washington D.C.

Rodriguez-Valera, F., Martin-Cuadrado, A-B., Rodriguez-Brito, B., Pasić, L., T Thingstad, F., Rohwer, F. et al. (2009). Explaining microbial population genomics through phage predation. Nature Reviews. Microbiology. 7, pp. 828-36. doi: $10.1038 /$ nrmicro2235.

Rose, J.B., Farrah, S.R., Harwood, V.J., Levine, A.D., Lukasik, J., Menendez, P. et al. (2004). Reductions of Pathogens, Indicator Bacteria, and Alternative Indicators by Wastewater Treatment and Reclamation Processes. Report 00-PUM-2T.

Rose, J.B., Farrah, S.R., Harwood, V.J., Levine, A., Lukasik, J., Menendez, P. et al. (2004). Reduction of pathogens, indicator bacteria, and alternative indicators by wastewater treatment and reclamation processes. Water Science and Technology: Water Supply.

Rubiano, M-E., Agulló-Barceló, M., Casas-Mangas, R., Jofre, J. and Lucena, F. (2012). Assessing the effects of tertiary treated wastewater reuse on a Mediterranean river (Llobregat, NE Spain): pathogens and indicators [corrected]. Environmental Science and Pollution Research International. 19, pp. 1026-32. doi: 10.1007/s11356-011-0562-9.

Salter, R.S. and Durbin, G.W. (2012). Modified USEPA method 1601 to indicate viral contamination of groundwater. Journal - American Water Works Association. 104, pp. E480-E488. doi: 10.5942/jawwa.2012.104.0115.

Schaper, M., Durán, A.E. and Jofre, J. (2002). Comparative resistance of phage isolates of four genotypes of f-specific RNA bacteriophages to various inactivation processes. Applied and Environmental Microbiology. 68, pp. $3702-7$.

Schaper, M. and Jofre, J. (2000). Comparison of methods for detecting genotypes of F-specific RNA bacteriophages and fingerprinting the origin of faecal pollution in water samples. Journal of Virological Methods. 89, pp. 1-10.

Schaper, M., Jofre, J., Uys, M. and Grabow, W.O.K. (2002). Distribution of genotypes of F-specific RNA bacteriophages in human and non-human sources of faecal pollution in South Africa and Spain. Journal of Applied Microbiology. 92, pp. 657-67.

Schulze, E. and Lenk, J. (1983). Concentration of coliphages from drinking water by $\mathrm{Mg}(\mathrm{OH}) 2$ flocculation. Die Naturwissenschaften. 70, pp. 612-3.

Sinton, L.W., Finlay, R.K. and Lynch, P.A. (1999). Sunlight inactivation of fecal bacteriophages and bacteria in sewagepolluted seawater. Applied and Environmental Microbiology. 65, pp. 3605-13.

Sinton, L.W., Hall, C.H., Lynch, P.A. and Davies-Colley, R.J. (2002). Sunlight inactivation of fecal indicator bacteria and bacteriophages from waste stabilization pond effluent in fresh and saline waters. Applied and Environmental Microbiology. 68, pp. 1122-31.

Sirikanchana, K., Wangkahad, B. and Mongkolsuk, S. (2014). The capability of non-native strains of Bacteroides bacteria to detect bacteriophages as faecal indicators in a tropical area. Journal of Applied Microbiology. 117, pp. 1820-9. doi: 10.1111/jam.12646.

Skraber, S., Gantzer, C., Maul, A. and Schwartzbrod, L. (2002). Fates of bacteriophages and bacterial indicators in the Moselle river (France). Water Research. 36, pp. 3629-37.

Skraber, S., Gassilloud, B. and Gantzer, C. (2004). Comparison of coliforms and coliphages as tools for assessment of viral contamination in river water. Applied and Environmental Microbiology. 70, pp. 3644-9. doi: 10.1128/AEM.70.6.3644-3649.2004.

Sobsey, M.D., Schwab, K.J. and Handzel, T.R. (1990). A Simple Membrane Filter Method to Concentrate and Enumerate Male-Specific RNA Coliphages (PDF). Journal - American Water Works Association. 82, pp. 52-59.

Soriano, G., Esparcia, O., Montemayor, M., Guarner-Argente, C., Pericas, R., Torras, X. et al. (2011). Bacterial DNA in the 
diagnosis of spontaneous bacterial peritonitis. Alimentary Pharmacology and Therapeutics. 33, pp. 275-84. doi: 10.1111/j.1365-2036.2010.04506.x.

Stenström, T.A. and Carlander, A. (2001). Occurrence and die-off of indicator organisms in the sediment in two constructed wetlands. Water science and technology : a journal of the International Association on Water Pollution Research. 44, pp. $223-30$.

Stetler, R.E. (1984). Coliphages as indicators of enteroviruses. Applied and Environmental Microbiology. 48, pp. 668-70.

Stewart-Pullaro, J., Daugomah, J.W., Chestnut, D.E., Graves, D.A., Sobsey, M.D. and Scott, G.I. (2006). F+ RNA coliphage typing for microbial source tracking in surface waters. Journal of Applied Microbiology. 101, pp. 1015-26. doi: 10.1111/j.1365-2672.2006.03011.x.

Stiegel, P.D., Mann, M. and Dalton, M. (2013). Alternate Indicator Organisms for Reclaimed Water in North Carolina. Proceedings of the Water Environment Federation. 2013, pp. 107-114. doi: 10.2175/193864713813503558.

Suttle, C.A. (1994). The significance of viruses to mortality in aquatic microbial communities. Microbial Ecology. 28, pp. 237-43. doi: 10.1007/BF00166813.

Symonds, E.M., Verbyla, M.E., Lukasik, J.O., Kafle, R.C., Breitbart, M. and Mihelcic, J.R. (2014). A case study of enteric virus removal and insights into the associated risk of water reuse for two wastewater treatment pond systems in Bolivia. Water Research. 65, doi: 10.1016/j.watres.2014.07.032.

Tartera, C. and Jofre, J. (1987). Bacteriophages active against Bacteroides fragilis in sewage-polluted waters. Applied and Environmental Microbiology. 53, pp. 1632-7.

Taylor, M.B., Cox, N., Vrey, M.A. and Grabow, W.O. (2001). The occurrence of hepatitis A and astroviruses in selected river and dam waters in South Africa. Water Research. 35, pp. 2653-60.

T Thingstad, F., Vlaage, S., Storesund, J.E., Sandaa, R-A. and Giske, J. (2014). A theoretical analysis of how strain-specific viruses can control microbial species diversity. Proceedings of the National Academy of Sciences of the United States of America. 111, pp. 7813-8. doi: 10.1073/pnas.1400909111.

van Asperen, I.A., Medema, G., Borgdorff, M.W., Sprenger, M.J. and Havelaar, A.H. (1998). Risk of gastroenteritis among triathletes in relation to faecal pollution of fresh waters. International Journal of Epidemiology. 27, pp. 309-15.

Venegas, C., Diez, H., Blanch, A.R., Jofre, J. and Campos, C. (2015). Microbial source markers assessment in the Bogotá River basin (Colombia). Journal of Water and Health. 13, pp. 801-10. doi: 10.2166/wh.2015.240.

Viau, E.J., Lee, D. and Boehm, A.B. (2011). Swimmer risk of gastrointestinal illness from exposure to tropical coastal waters impacted by terrestrial dry-weather runoff. Environmental Science and Technology. 45, pp. 7158-65. doi: 10.1021/es200984b.

von Schirnding, Y.E., Kfir, R., Cabelli, V., Franklin, L. and Joubert, G. (1992). Morbidity among bathers exposed to polluted seawater. A prospective epidemiological study. South African medical journal = Suid-Afrikaanse tydskrif vir geneeskunde. 81, pp. 543-6.

Wade, T.J., Sams, E., Brenner, K.P., Haugland, R., Chern, E., Beach, M. et al. (2010). Rapidly measured indicators of recreational water quality and swimming-associated illness at marine beaches: a prospective cohort study. Environmental Health : a Global Access Science Source. 9, pp. 66. doi: 10.1186/1476-069X-9-66.

Weinbauer, M.G. (2004). Ecology of prokaryotic viruses. FEMS Microbiology Reviews. 28, pp. 127-81. doi: 10.1016/j.femsre.2003.08.001.

Western Australian Government (2012). Western Australia Guidelines for Biosolids Management. Perth. Australia.

Westrell, T., Teunis, P., Van Den Berg, H., Lodder, W., Ketelaars, H., Stenström, T.Axel et al. (2006). Short- and long-term variations of norovirus concentrations in the Meuse river during a 2-year study period. Water Research. 40, pp. 2613-20. 
doi: 10.1016/j.watres.2006.05.019.

Wicki, M., Auckenthaler, A., Felleisen, R., Tanner, M. and Baumgartner, A. (2011). Novel Bacteroides host strains for detection of human- and animal-specific bacteriophages in water. Journal of Water and Health. 9, pp. 159-68. doi: 10.2166/wh.2010.165.

Wiedenmann, A., Krüger, P., Dietz, K., López-Pila, J.M., Szewzyk, R. and Botzenhart, K. (2006). A randomized controlled trial assessing infectious disease risks from bathing in fresh recreational waters in relation to the concentration of Escherichia coli, intestinal enterococci, Clostridium perfringens, and somatic coliphages. Environmental Health Perspectives. 114, pp. 228-36.

Wiggins, B.A. and Alexander, M. (1985). Minimum bacterial density for bacteriophage replication: implications for significance of bacteriophages in natural ecosystems. Applied and Environmental Microbiology. 49, pp. 19-23.

Wigginton, K.R. and Kohn, T. (2012). Virus disinfection mechanisms: the role of virus composition, structure, and function. Current Opinion in Virology. 2, pp. 84-9. doi: 10.1016/j.coviro.2011.11.003.

Wolf, S., Hewitt, J. and Greening, G.E. (2010). Viral multiplex quantitative PCR assays for tracking sources of fecal contamination. Applied and Environmental Microbiology. 76, pp. 1388-94. doi: 10.1128/AEM.02249-09.

Woody, M.A. and Cliver, D.O. (1997). Replication of coliphage Q beta as affected by host cell number, nutrition, competition from insusceptible cells and non-FRNA coliphages. Journal of Applied Microbiology. 82, pp. 431-40.

Yahya, M., Hmaied, F., Jebri, S., Jofre, J. and Hamdi, M. (2015). Bacteriophages as indicators of human and animal faecal contamination in raw and treated wastewaters from Tunisia. Journal of Applied Microbiology. 118, pp. 1217-25. doi: 10.1111/jam.12774.

Zhang, K. and Farahbakhsh, K. (2007). Removal of native coliphages and coliform bacteria from municipal wastewater by various wastewater treatment processes: implications to water reuse. Water Research. 41, pp. 2816-24. doi: 10.1016/j.watres.2007.03.010. 